\title{
Single, double or multiple-injection techniques for axillary brachial plexus block for hand, wrist or forearm surgery in adults (Review)
}

\author{
Chin KJ, Handoll HHG
}

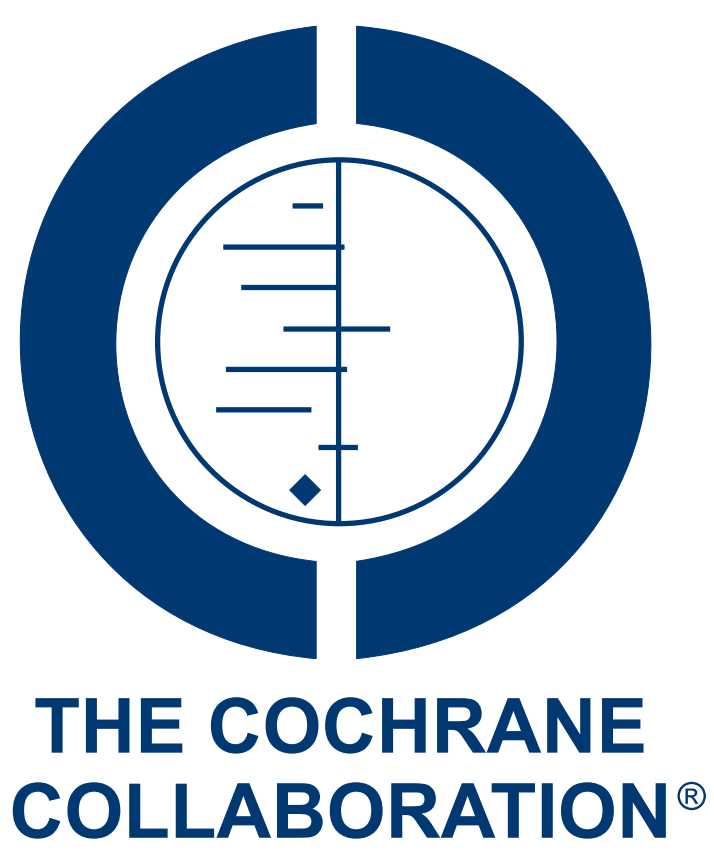

This is a reprint of a Cochrane review, prepared and maintained by The Cochrane Collaboration and published in The Cochrane Library 2011, Issue 7

http://www.thecochranelibrary.com

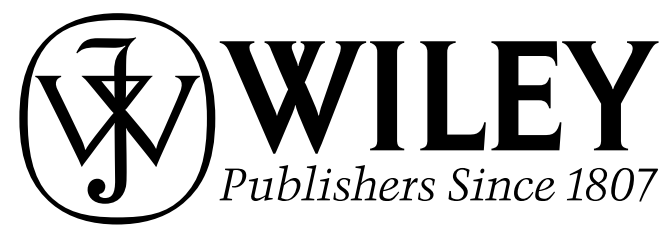

Single, double or multiple-injection techniques for axillary brachial plexus block for hand, wrist or forearm surgery in adults (Review) Copyright (@) 201 I The Cochrane Collaboration. Published by John Wiley \& Sons, Ltd. 
TABLE OF CONTENTS

HEADER . . . . . . . . . . . . . . . . . . . . . . . . . . . . . . . . 1

ABSTRACT . . . . . . . . . . . . . . . . . . . . . . . . . . . . . . . . . . . . . . . . . . . . . . . . .

PLAIN LANGUAGE SUMMARY . . . . . . . . . . . . . . . . . . . . . . . . . . . . . . . . . . . . . . . . 2

SUMMARY OF FINDINGS FOR THE MAIN COMPARISON . . . . . . . . . . . . . . . . . . . . . . 2

BACKGROUND . . . . . . . . . . . . . . . . . . . . . . . . . . . . . . . . . . . . 5

OBJECTIVES . . . . . . . . . . . . . . . . . . . . . . . . . . . . . . . . . . . . . . . . . 5

METHODS . . . . . . . . . . . . . . . . . . . . . . . . . . . . . . . . . . . . . . 6

RESULTS . . . . . . . . . . . . . . . . . . . . . . . . . . . . . . . . . . . . . . . . 8

Figure 1. . . . . . . . . . . . . . . . . . . . . . . . . . . . . . . . . . . . . . . . . 9

Figure $2 . \quad$. . . . . . . . . . . . . . . . . . . . . . . . . . . . . . . . . . . . . 13

Figure 3. . . . . . . . . . . . . . . . . . . . . . . . . . . . . . . . . . . . . . 14

Figure 4. . . . . . . . . . . . . . . . . . . . . . . . . . . . . . . . . . . . . . 16

Figure 5. . . . . . . . . . . . . . . . . . . . . . . . . . . . . . . . . . . . . . 17

Figure 6. . . . . . . . . . . . . . . . . . . . . . . . . . . . . . . . . . . . . . . . . . . . . . $\quad 19$

ADDITIONAL SUMMARY OF FINDINGS . . . . . . . . . . . . . . . . . . . . . . . . . . . . . $\quad 20$

DISCUSSION . . . . . . . . . . . . . . . . . . . . . . . . . . . . . . . . . . . . . . . . . . . 25

AUTHORS' CONCLUSIONS . . . . . . . . . . . . . . . . . . . . . . . . . . . . . . . . . . . . . 26

ACKNOWLEDGEMENTS . . . . . . . . . . . . . . . . . . . . . . . . . . . . . . . . . . . . 27

REFERENCES . . . . . . . . . . . . . . . . . . . . . . . . . . . . . . . . . . . . . . . 27

CHARACTERISTICS OF STUDIES . . . . . . . . . . . . . . . . . . . . . . . . . . . . . . . . . . . 30

DATA AND ANALYSES . . . . . . . . . . . . . . . . . . . . . . . . . . . . . . . . . . . . . . . . . . . . . . 65

Analysis 1.1. Comparison 1 Double versus single-injection technique, Outcome 1 Primary anaesthesia failure (incomplete

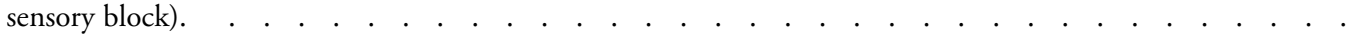

Analysis 1.2. Comparison 1 Double versus single-injection technique, Outcome 2 Primary anaesthesia failure - subgrouped

Analysis 1.3 . Comparison 1 Double versus single-injection technique, Outcome 3 Complete failure of block: general anaesthesia or new plexus block. . . . . . . . . . . . . . . . . . . . . . . . . . . . 70

Analysis 1.4. Comparison 1 Double versus single-injection technique, Outcome 4 Incomplete motor block. $\quad$. . . $\quad 71$

Analysis 1.5. Comparison 1 Double versus single-injection technique, Outcome 5 Secondary analgesia failure. . . $\quad$. 72

Analysis 1.6. Comparison 1 Double versus single-injection technique, Outcome 6 Timing (in minutes). . . . . . . 73

Analysis 1.7. Comparison 1 Double versus single-injection technique, Outcome 7 Complications during nerve block. 74

Analysis 1.8. Comparison 1 Double versus single-injection technique, Outcome 8 Adverse effects (> 24 hours). $\quad . \quad 75$

Analysis 1.9. Comparison 1 Double versus single-injection technique, Outcome 9 Patient discomfort and dissatisfaction with method. . . . . . . . . . . . . . . . . . . . . . . . . . . . . . . . . . . .

Analysis 2.1. Comparison 2 Multiple versus single-injection technique, Outcome 1 Primary anaesthesia failure (incomplete sensory block). . . . . . . . . . . . . . . . . . . . . . . . . . . . . . . . . . 76

Analysis 2.2. Comparison 2 Multiple versus single-injection technique, Outcome 2 Primary anaesthesia failure - subgrouped by outcome definition. . . . . . . . . . . . . . . . . . . . . . . . . . . . . . . . . . . . . . . . . . . . . .

Analysis 2.3. Comparison 2 Multiple versus single-injection technique, Outcome 3 Complete failure of block: general anaesthesia or new plexus block.

Analysis 2.4. Comparison 2 Multiple versus single-injection technique, Outcome 4 Incomplete motor block. $\quad . \quad . \quad . \quad 78$

Analysis 2.5. Comparison 2 Multiple versus single-injection technique, Outcome 5 Secondary analgesia failure. $\quad$. $\quad 79$

Analysis 2.6. Comparison 2 Multiple versus single-injection technique, Outcome 6 Timing (in minutes). . . . $\quad . \quad 80$

Analysis 2.7. Comparison 2 Multiple versus single-injection technique, Outcome 7 Complications during nerve block. 81

Analysis 2.8. Comparison 2 Multiple versus single-injection technique, Outcome 8 Adverse effects $>24$ hours. $\quad . \quad 82$

Analysis 2.9. Comparison 2 Multiple versus single-injection technique, Outcome 9 Patient discomfort and dissatisfaction with method.

Analysis 3.1. Comparison 3 Multiple versus double-injection technique, Outcome 1 Primary anaesthesia failure (incomplete sensory block). . . . . . . . . . . . . . . . . . . . . . . . . . . . . . . . . .

Analysis 3.2. Comparison 3 Multiple versus double-injection technique, Outcome 2 Primary anaesthesia failure subgrouped by outcome definition.

Single, double or multiple-injection techniques for axillary brachial plexus block for hand, wrist or forearm surgery in adults (Review)

Copyright @ 201 I The Cochrane Collaboration. Published by John Wiley \& Sons, Ltd. 
Analysis 3.3. Comparison 3 Multiple versus double-injection technique, Outcome 3 Complete failure of block: general anaesthesia or new plexus block. . . . . . . . . . . . . . . . . . . . . . . . . . . .

Analysis 3.4. Comparison 3 Multiple versus double-injection technique, Outcome 4 Incomplete motor block. . . . $\quad 87$

Analysis 3.5. Comparison 3 Multiple versus double-injection technique, Outcome 5 Secondary analgesia failure. . $\quad . \quad 88$

Analysis 3.6. Comparison 3 Multiple versus double-injection technique, Outcome 6 Timing (in minutes). . . . . $\quad 89$

Analysis 3.7. Comparison 3 Multiple versus double-injection technique, Outcome 7 Complications during nerve block. 91

Analysis 3.8. Comparison 3 Multiple versus double-injection technique, Outcome 8 Adverse effects $>24$ hours. . . 93

Analysis 3.9. Comparison 3 Multiple versus double-injection technique, Outcome 9 Patient discomfort and dissatisfaction with method. . . . . . . . . . . . . . . . . . . . . . . . . . . . . . . . . . . 94

APPENDICES . . . . . . . . . . . . . . . . . . . . . . . . . . . . . . . . . . . . . 94

WHAT'S NEW . . . . . . . . . . . . . . . . . . . . . . . . . . . . . . . . . . . . . 106

HISTORY . . . . . . . . . . . . . . . . . . . . . . . . . . . . . . . . . . . . . . . 107

CONTRIBUTIONS OF AUTHORS . . . . . . . . . . . . . . . . . . . . . . . . . . . . . . . . . . . . . . . . 107

DECLARATIONS OF INTEREST ．．．．．．．．．．．．．．．．．．．．．．．．．．．．．１08

SOURCES OF SUPPORT . . . . . . . . . . . . . . . . . . . . . . . . . . . . . . . . . 108

DIFFERENCES BETWEEN PROTOCOL AND REVIEW . . . . . . . . . . . . . . . . . . . . . 108

INDEX TERMS . . . . . . . . . . . . . . . . . . . . . . . . . . . . . . . . . . . . . . . . . . . . . . . 108 


\title{
Single, double or multiple-injection techniques for axillary brachial plexus block for hand, wrist or forearm surgery in adults
}

\author{
Ki Jinn Chin ${ }^{1}$, Helen HG Handoll ${ }^{2}$ \\ ${ }^{1}$ Department of Anesthesia, University of Toronto, Toronto, Canada. ${ }^{2}$ Health and Social Care Institute, Teesside University, Middles- \\ borough, UK \\ Contact address: Ki Jinn Chin, Department of Anesthesia, University of Toronto, Toronto Western Hospital, 399 Bathurst Street, \\ Toronto, Ontario, M5T 2S8, Canada. gasgenie@yahoo.co.uk. \\ Editorial group: Cochrane Anaesthesia Group. \\ Publication status and date: New search for studies and content updated (no change to conclusions), published in Issue 7, 2011. \\ Review content assessed as up-to-date: 13 March 2011.
}

Citation: Chin KJ, Handoll HHG. Single, double or multiple-injection techniques for axillary brachial plexus block for hand, wrist or forearm surgery in adults. Cochrane Database of Systematic Reviews 2011, Issue 7. Art. No.: CD003842. DOI: 10.1002/14651858.CD003842.pub3.

Copyright (C) 2011 The Cochrane Collaboration. Published by John Wiley \& Sons, Ltd.

\section{A B S T R A C T}

\section{Background}

Regional anaesthesia comprising axillary block of the brachial plexus is a common anaesthetic technique for distal upper limb surgery. This is an update of a review first published in 2006.

\section{Objectives}

To compare the relative effects of single, double or multiple injections for axillary block of the brachial plexus for distal upper limb surgery.

\section{Search strategy}

We searched the Cochrane Central Register of Controlled Trials (CENTRAL) (The Cochrane Library), MEDLINE, EMBASE and reference lists of trials. We contacted trial authors. The date of the last search was March 2011 (updated from March 2005).

\section{Selection criteria}

We included randomized controlled trials that compared double with single-injection techniques, multiple with single-injection techniques, or multiple with double-injection techniques for axillary block in adults undergoing surgery of the distal upper limb. We excluded trials using ultrasound-guided techniques.

\section{Data collection and analysis}

We performed independent study selection, risk of bias assessment and data extraction. We undertook meta-analysis.

Main results

The 20 included trials involved a total of 2098 participants who received regional anaesthesia for hand, wrist, forearm or elbow surgery. The trial design and conduct were generally adequate although several trials failed to monitor longer-term effects. 
Eight trials comparing double versus single injections showed a statistically significant decrease in primary anaesthesia failure (RR 0.51 , $95 \%$ CI 0.30 to 0.85 ). Subgroup analysis by method of nerve location showed that the effect size was greater when neurostimulation was used rather than the transarterial technique.

Seven trials comparing multiple with single injections showed a statistically significant decrease in primary anaesthesia failure (RR 0.28 , 95\% CI 0.16 to 0.48 ) and of incomplete motor block (RR $0.61,95 \%$ CI 0.39 to 0.96 ) in the multiple injection group.

Eleven trials comparing multiple with double injections showed a statistically significant decrease in primary anaesthesia failure (RR $0.28,95 \%$ CI 0.20 to 0.40 ) and of incomplete motor block (RR 0.55, 95\% CI 0.36 to 0.85 ) in the multiple injection group.

Tourniquet pain was significantly reduced with multiple injections compared with double injections (RR 0.53, 95\% CI 0.33 to 0.84 ). Otherwise, there were no statistically significant differences between groups in any of the three comparisons on secondary analgesia failure, complications and patient discomfort. The time for block performance was significantly shorter for single and double injections compared with multiple injections.

\section{Authors' conclusions}

This review provides evidence that multiple injection techniques using nerve stimulation for axillary plexus block produce more effective anaesthesia than either double or single injection techniques. However, there was insufficient evidence for a significant difference in other outcomes, including safety.

\section{PLAIN LANGUAGESUMMARY}

\section{Anaesthesia for hand and forearm surgery via single, double or multiple injections placed close to nerves in the armpit}

A common method of regional anaesthesia for hand, wrist or forearm surgery is to inject local anaesthetic into the tissues surrounding nerves in the armpit. This is because in the armpit (axilla) the key nerves for the lower part of the arm are close together and are easier to locate. This type of anaesthesia is called axillary brachial plexus block. Successful blocking of the nerves produces a numb and limp arm that enables pain-free surgery. This review compared the effects of single, double and multiple (three or four) injections of local anaesthetic.

The 20 included randomized controlled trials involved a total of 2098 participants who were given regional anaesthesia for hand, wrist, forearm or elbow surgery. While the trials used generally adequate methods, several trials did not monitor longer-term effects. Eight trials compared double versus single injections. These found that fewer people in the double injection group required additional anaesthesia. However, the effect was more certain in the four trials where the nerves were located using the precise technique of neurostimulation. In the seven trials comparing multiple with single injections, and the 11 trials comparing multiple with double injections, there were significantly fewer people needing extra anaesthesia in the multiple injection groups. In addition, fewer patients in the multiple injection group experienced tourniquet pain compared to the double injection group. There were no other statistically significant differences in complications or patient discomfort between the two groups for any of the three comparisons. Single and double injections took less time to perform than multiple injections, but this did not reduce the total time required for adequate surgical anaesthesia to be established.

Overall, the evidence from these trials showed that injections of anaesthetic close to three or four nerves at the armpit provide more complete anaesthesia for hand and forearm surgery than one or two injections. There was, however, not enough evidence to determine if there was a significant difference in the other outcomes, including safety. 


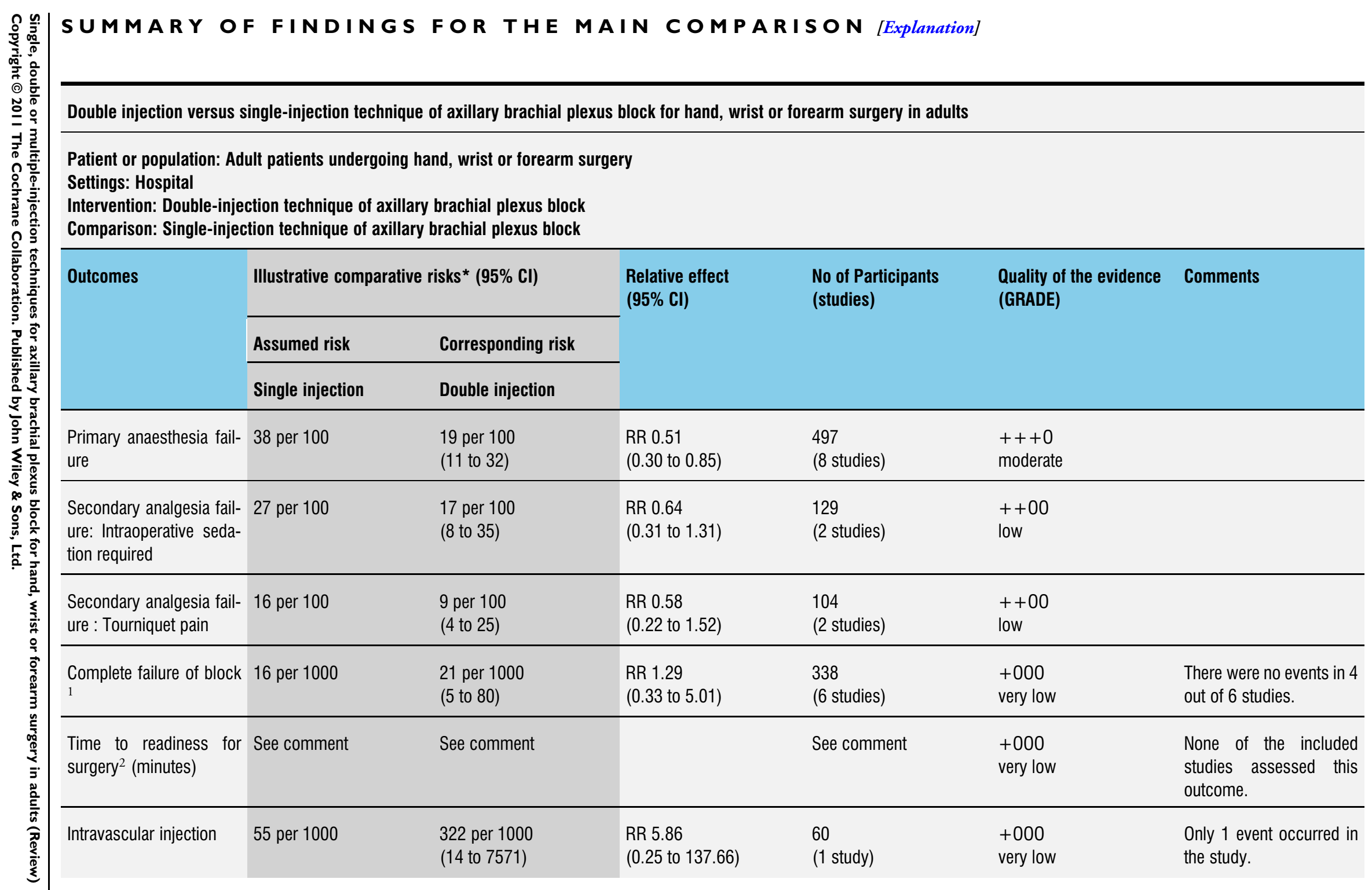




\begin{tabular}{lllll}
\hline $\begin{array}{l}\text { Adverse effects lasting } 13 \text { per } 1000 \\
\text { more than } 24 \text { hours }\end{array}$ & $\begin{array}{l}16 \text { per } 1000 \\
(4 \text { to } 77)\end{array}$ & $\begin{array}{l}\text { RR } 1.25 \\
(0.27 \text { to } 5.89)\end{array}$ & $\begin{array}{l}119 \\
\text { (2 studies) }\end{array}$ & $\begin{array}{l}\text { There were no events in } 1 \\
\text { of the } 2 \text { studies. }\end{array}$ \\
\hline
\end{tabular}

*The assumed risk for the 'control' group is based on the mean value of the results for all single injection groups in the included trials reporting the outcome. The corresponding risk (and its $95 \%$ confidence interval) is based on the assumed risk in the comparison group and the relative effect of the intervention (and its $95 \% \mathrm{Cl}$ ).

Cl: Confidence interval; RR: Risk Ratio

GRADE Working Group grades of evidence

High quality: Further research is very unlikely to change our confidence in the estimate of effect.

Moderate quality: Further research is likely to have an important impact on our confidence in the estimate of effect and may change the estimate.

Low quality: Further research is very likely to have an important impact on our confidence in the estimate of effect and is likely to change the estimate.

Very low quality: We are very uncertain about the estimate.

1. Complete failure of block is defined as the need for general anaesthesia or a new plexus block to provide surgical anaesthesia.

2. Time to readiness for surgery is defined as the time required to perform the block plus the time from completion of the block to

development of surgical anaesthesia.

3. Adverse effects lasting more than 24 hours refers mainly to neurological symptoms or deficits in the arm that was blocked. 


\section{B A C K G R O U N D}

An increase in the use of ambulatory hand surgery has generated the need for a method of regional anaesthesia that is comparable to general anaesthesia. Most anaesthesiologists agree that the regional technique has to satisfy four criteria for inclusion in their clinical practice. It should be effective, fast, safe and cause the patient either no, or only minimal, pain.

The three main nerves of the upper extremity (median, ulnar and radial) are enclosed in the axilla by the fascial neurovascular sheath. This limits the spread of fluid. Burnham 1958 discovered that filling this sheath with local anaesthetic could simplify the blocking procedure to a single axillary injection. The fourth main nerve of the upper extremity, the musculocutaneous nerve, usually leaves the brachial plexus more proximally, at the cord level in the infraclavicular area. De Jong 1961, using the mathematical formula for a cylinder and assuming equal proximal and distal spread from the injection site, calculated that $42 \mathrm{ml}$ of local anaesthetic was sufficient to reach this area and thus anaesthetize the whole arm in the average adult. Thompson and Rorie (Thompson 1983) were the first to show (by computed tomograms) that the median, ulnar and radial nerves lie in separate fascial compartments within the neurovascular sheath. Small septae divide the neurovascular sheath and limit the circumferential spread of local anaesthetic. This provided a rational explanation for incomplete blocks. The anatomical study by Lassale and Ang, based on plaster injection into the axillary perivascular space, did not confirm the existence of a true neurovascular sheath (Lassale 1984). In a similar study, Vester-Andersen et al did not find the fascial septae separating the nerves but noticed that in all dissections only the median and ulnar nerves were engulfed by injected gelatine (Vester-Andersen 1986a). The musculocutaneous and radial nerves had either a partial contact or none at all. Partridge et al found interneural septae which were easily broken by injection of dyed latex (Partridge 1987). They therefore concluded that the septae did not limit fluid spread and had no clinical significance for anaesthesia. All these reports were based on either personal experience in a small number of patients or on cadaver studies, and none of them were controlled.

Before the 1960s, the prevalent block techniques were double or multiple axillary injections. After De Jong's report in 1961, the single-injection technique, being the simplest, became standard. Entry into the fascial neurovascular sheath was signalled either by a fascial 'click' or elicitation of paraesthesiae in the arm. The proximal spread of local anaesthetic was considered mandatory for success. The incomplete blocks were explained by insufficient volume of local anaesthetic. in the 1980s, however, Vester-Andersen et al repeatedly showed that, in spite of increased local anaesthetic volumes or concentrations, the incidence of incomplete axillary blocks was high (Vester-Andersen 1984a; Vester-Andersen 1984b; Vester-Andersen 1986a). In the early 1990s, the double-injection transarterial technique using high doses of local anaesthetic gained popularity in the USA (Stan 1995; Urban 1994). In this technique, transfixion of the axillary artery was deliberately achieved to confirm entry into the neurovascular sheath; local anaesthetic was then injected behind (posterior to) as well as in front of (anterior to) the artery, in anticipation that this would increase the chance of spread to all components of the plexus.

At approximately the same time, technical development of peripheral nerve stimulators and insulated blunt needles allowed electrolocation of the individual plexus nerves. While electrolocation (also known as neurostimulation) may be applied to single and double-injection techniques, its greatest advantage is that it allows targeted injection around three or more of the main nerves to the arm. This is known as the multiple-injection technique. Lavoie et al and Koscielniak-Nielsen et al reported that this technique was superior to the single-injection method (K-Nielsen 1997a; Lavoie 1992a), and Koscielniak-Nielsen et al reported its superiority over the transarterial technique (K-Nielsen 1998a; K-Nielsen 1999c). Coventry et al and Sia et al drew similar conclusions when comparing triple injection with double injection (Coventry 2001a; Sia 2001a).

\section{Why it is important to do this review}

The first version of our review (Handoll 2006) reported that no recommendations were available as to which of these techniques (single, double or multiple injection) were preferable, and that the choice is left to the personal preferences of the anaesthesiologist. The findings of the systematic review were in favour of multiple injection techniques using nerve stimulation for axillary plexus block in terms of providing more effective anaesthesia than either double or single injection techniques. It emphasized, however, that there was insufficient evidence for other outcomes, especially longer-term outcomes and safety. This update fulfils our stated intention to maintain this review in the light of any new evidence from randomized trials, but there is also a need to acknowledge relevant developments in this field that affect its importance. Our review (Handoll 2006) suggested that "ultrasound-guided injections may supplant nerve stimulation techniques" and indeed since 2006 ultrasound-guided axillary block has become increasingly popular. This technique is a multiple injection technique where each of the four individual nerves are identified and targeted under direct vision. It is clinically very different from the anatomical landmark-guided techniques described above and hence we have explicitly excluded trials using ultrasound-guided techniques from the review. This review sought to determine which of the landmark-guided techniques (single, double or multiple injection) are preferable in performing axillary block of the brachial plexus.

\section{O B J E C T IVES}

To compare the relative effects (benefits and harms) of the three injection techniques (single, double and multiple) of axillary block 
of the brachial plexus for distal upper extremity surgery. We considered these effects primarily in terms of anaesthetic effectiveness; the incidence of complications (neurological and vascular); and pain and discomfort caused by the block performance.

\section{METHODS}

\section{Criteria for considering studies for this review}

\section{Types of studies}

We included randomized controlled trials (RCTs) that compared single with double or multiple injection techniques, or double with multiple injection techniques, for axillary block.

\section{Types of participants}

We included adults (generally over 18 years of age) undergoing surgery of the distal upper extremity: the hand, wrist, forearm, elbow, or some combination thereof. We excluded trials that focused on children only.

\section{Types of interventions}

1. Single injection in the axilla (including injection through a catheter)

2. Double injection in the axilla (transarterial, elicitation of two paraesthesiae, electrolocation of two nerves, insertion of two needles)

3. Multiple injection techniques in the axilla (three or more paraesthesiae or electrolocations) regardless of the local anaesthetic, $\mathrm{pH}$ adjustment or additives

In this review, multiple injection techniques, in particular nerve stimulator guided multiple injection techniques, were the 'experimental' intervention. Single injection (perivascular) and double injection (transarterial) techniques represented 'standard' interventions. For comparisons of single versus double injection techniques, the single injection was the 'standard'.

We distinguished between 'guided' (neurostimulation as the endpoint for nerve location) and 'blind' (fascial clicks, paraesthesia, or arterial puncture as the endpoints for nerve location) injection techniques.

Exclusions: ultrasound-guided techniques of nerve location (added as an exclusion in the current update); and routine supplementary analgesia (local anaesthetic infiltration of the surgical site; general anaesthetics and systemic opioids), with the exception of systemic opioids when used as a component of sedation (for example, small doses of opioids used in combination with benzodiazepines).

\section{Types of outcome measures}

\section{Primary outcomes}

Primary analgesia or anaesthesia failure. This was represented by the use of any additional anaesthetic or surgical intervention to ensure adequate surgical anaesthesia. This outcome can be measured or defined in various ways. It can be: a) incomplete overall sensory block or analgesia; or b) incomplete or inadequate sensory block or analgesia for the specific surgery undertaken at an appropriate (generally 30 minutes) time interval after completion of the blocking procedure.

Failure is also indicated by one or more of the following: use of supplementary analgesia either to ensure a) complete overall analgesia, or b) analgesia for the surgical site; change in anaesthesia method, such as recourse to general anaesthesia; and the curtailment or modification of the planned surgical procedure due to inadequate anaesthesia. We also reported incomplete motor block.

\section{Secondary outcomes}

1. Secondary analgesia failure, such as surgical site pain, tourniquet pain or need for intraoperative sedation.

2. Timing, primarily time to achieve readiness for surgery.

3. Complications and adverse effects: these included vascular complications such as haematoma; accidental intravascular injection and its sequelae (tachycardia, dizziness, loss of consciousness, seizures); and neurological complications, including residual neurapraxias not related to surgical site, that were present for more than 24 hours.

4. Pain and discomfort during block performance.

\section{Search methods for identification of studies}

In the first version of this review (Handoll 2006) one author (Zbigniew J Koscielniak-Nielsen (ZK-N)) undertook the search (to August 2004) and Karen Hovhannisyan (KH) as Trial Search Coordinator, Cochrane Anaesthesia Review Group (CARG) supplemented this search (to March 2005).

For this update, we received search downloads for the following databases: the Cochrane Central Register of Controlled Trials (CENTRAL) (The Cochrane Library), MEDLINE and EMBASE from $\mathrm{KH}$. KH updated the database search strategies that had been used in the first version of this review and ran these (March 2011) (see Appendix 1). The search dates for these searches were:

- CENTRAL (The Cochrane Library Issue 3, 2011);

- Ovid MEDLINE (1956 to March Week 5, 2011);

- EMBASE (1980 to Week 14, 2011).

As before, we applied no language restrictions.

The description of the search methods used in the previous version of the review is given in Appendix 2. 


\section{Data collection and analysis}

\section{Selection of studies}

In the first version of the review, one review author (ZK-N) compiled a set of reports of controlled trials testing various aspects of axillary brachial plexus neural blockade for surgery of the distal upper limb, using the author-performed search strategy, supplemented by his personal reference collection. ZK-N provided $\mathrm{HH}$ with copies of the first pages (or more as required) of each report. Both authors independently selected a set of potentially eligible trials and then, based on full text versions, independently selected trials that met the review inclusion criteria. All disagreements were resolved by discussion.

$\mathrm{HH}$ checked through the supplementary search results (March 2005) from three databases and put forward eligible trials for selection and future consideration.

For this update, both of the current review authors (K-JC and $\mathrm{HH}$ ) independently selected potentially eligible trials from the search downloads of CENTRAL, MEDLINE and EMBASE that were provided by the CARG Trial Search Co-ordinator $(\mathrm{KH})$. Then, upon discussion and clarification of the inclusion criteria (see Differences between protocol and review), we independently selected trials from full-text versions.

\section{Data extraction and management}

In the first version of the review, three people (the two review authors and one other, Saúl Rugeles) performed data collection. For all versions, two people independently extracted trial information and results using a piloted data extraction form. Where available, we collected information on the following: trial methods (including methods of randomization and outcome assessment); details of the injection technique; the local anaesthetic agent; drugs used for sedation; baseline characteristics of the trial population (including sex, age, mental status and surgical interventions); and outcome measures such as pain and complications of the blocking procedure, as listed above. We resolved any differences by discussion, via email correspondence. We contacted trial authors for further details of their trials.

In the first version of the review, because ZK-N was the lead investigator of four included trials, the other review authors undertook independent data entry into Review Manager (RevMan 4.2) and performed the presentation and interpretation of these four trials. However we took note of feedback, particularly corrections, from ZK-N.

For this update, both of the current review authors (K-JC and $\mathrm{HH}$ ) independently extracted trial information and results using a piloted data extraction form as described above. We resolved any differences by discussion, via email correspondence. We contacted trial authors for further details of their trials. Both authors undertook independent data entry into Review Manager (RevMan 5.1).

\section{Assessment of risk of bias in included studies}

For the first version of the review, two people independently assessed adequacy of study design using an adaptation of the eightitem scoring scheme (see Appendix 3) formerly developed by CARG. We assessed the following items: allocation concealment; description of study inclusion and exclusion criteria; intention-totreat analysis (description of withdrawals); description of baseline characteristics of the trial population (in particular age, sex, mental status and type of surgery); comparability of care programmes other than the trial interventions (including anaesthetist experience with technique); outcome assessor blinding; and timing of outcome measurement (minimum 24 hours). As ZK-N was the lead investigator of four of the included trials in the first version of the review, these trials were reviewed independently of him. We resolved any differences by discussion.

For this update, we assessed risk of bias using the tool outlined in the Cochrane Handbook for Systematic Reviews of Interventions (Higgins 2009). This tool incorporates assessment of randomization (sequence generation and allocation concealment), blinding (of participants, treatment providers and outcome assessors), completeness of outcome data, selection of outcomes reported and other sources of bias. We considered all outcomes in our assessment of blinding and completeness of outcome data. We assessed two additional sources of bias: selection bias resulting from major imbalances in key baseline characteristics (age, sex, type of surgery, mental status); and performance bias, such as that resulting from a lack of comparability in the experience of the anaesthetist with the interventions being compared. One author $(\mathrm{HH})$ assessed risk of bias of the already included trials, drawing on the previous assessments. Both authors independently assessed the newly included trials. We resolved any differences by discussion.

\section{Measures of treatment effect}

We calculated risk ratios and $95 \%$ confidence intervals for dichotomous outcomes, and mean differences and 95\% confidence intervals for continuous outcomes.

\section{Assessment of heterogeneity}

Heterogeneity was assessed by visual inspection of the forest plot (the analysis) along with consideration of the $\mathrm{Chi}^{2}$ test for heterogeneity and the $\mathrm{I}^{2}$ statistic (Higgins 2003).

\section{Data synthesis}

We reviewed the data from the included studies qualitatively and then, where possible and appropriate, presented data in the analysis and combined the data quantitatively. We pooled results of comparable groups of trials using the fixed-effect model and 95\% confidence intervals. Where there was significant and unexplained heterogeneity among studies ( $\mathrm{P}<0.10$ using $\mathrm{Q}$ statistics), we applied the random-effects model. 


\section{Subgroup analysis and investigation of heterogeneity}

We planned subgroup analyses on the method of nerve location (paraesthesia, transarterial, nerve stimulation) and broad location of the surgery (hand, wrist, forearm and elbow). To test whether the subgroups were statistically significantly different from one another, we tested the interaction using the technique outlined by Altman and Bland (Altman 2003).

\section{Sensitivity analysis}

Where possible, we planned or undertook sensitivity analyses examining various aspects of trial and review methodology, including the effects of missing data and study quality (specifically allocation concealment and outcome assessor blinding).

\section{RE S U L T S}

\section{Description of studies}

See: Characteristics of included studies; Characteristics of excluded studies; Characteristics of studies awaiting classification.

\section{Results of the search}

In the first version of this review (Handoll 2006) 73 studies were initially identified, all of which involved investigation of some aspect of brachial plexus blockade for surgery of the distal upper limb. We rejected 55 studies at the first screening. The majority of rejected studies compared different types or doses of anaesthetic; the others investigated various physical aspects such as arm position, the use of digital pressure, different techniques and approaches. We included 12 of the 18 remaining studies; the other six were excluded for reasons given in the Characteristics of excluded studies table.

For the current update, both authors independently screened the search results from three databases: CENTRAL (602 references); EMBASE (723 references) and MEDLINE (651 references). We identified 18 articles related to new studies for potential inclusion, of which we excluded 10 after reviewing the full text reports or after some reconsideration or clarification of the inclusion criteria of the review. One article is currently awaiting translation and classification (Ramirez-Gomez 2010). The remaining seven newlyincluded articles related to eight trials (Hickey 1993; Imbelloni 2005; Rodriguez 2005; Rodriguez 2008; Sia 2010a; Sia 2010b; Sia 2010c; Turkan 2002). One of the seven articles was a letter (Geier 2006) commenting on Imbelloni 2005. Three trials (Sia 2010a; Sia 2010b; Sia 2010c) were run concurrently and reported in the same article (see Figure 1). 
Figure I. Search flow diagram

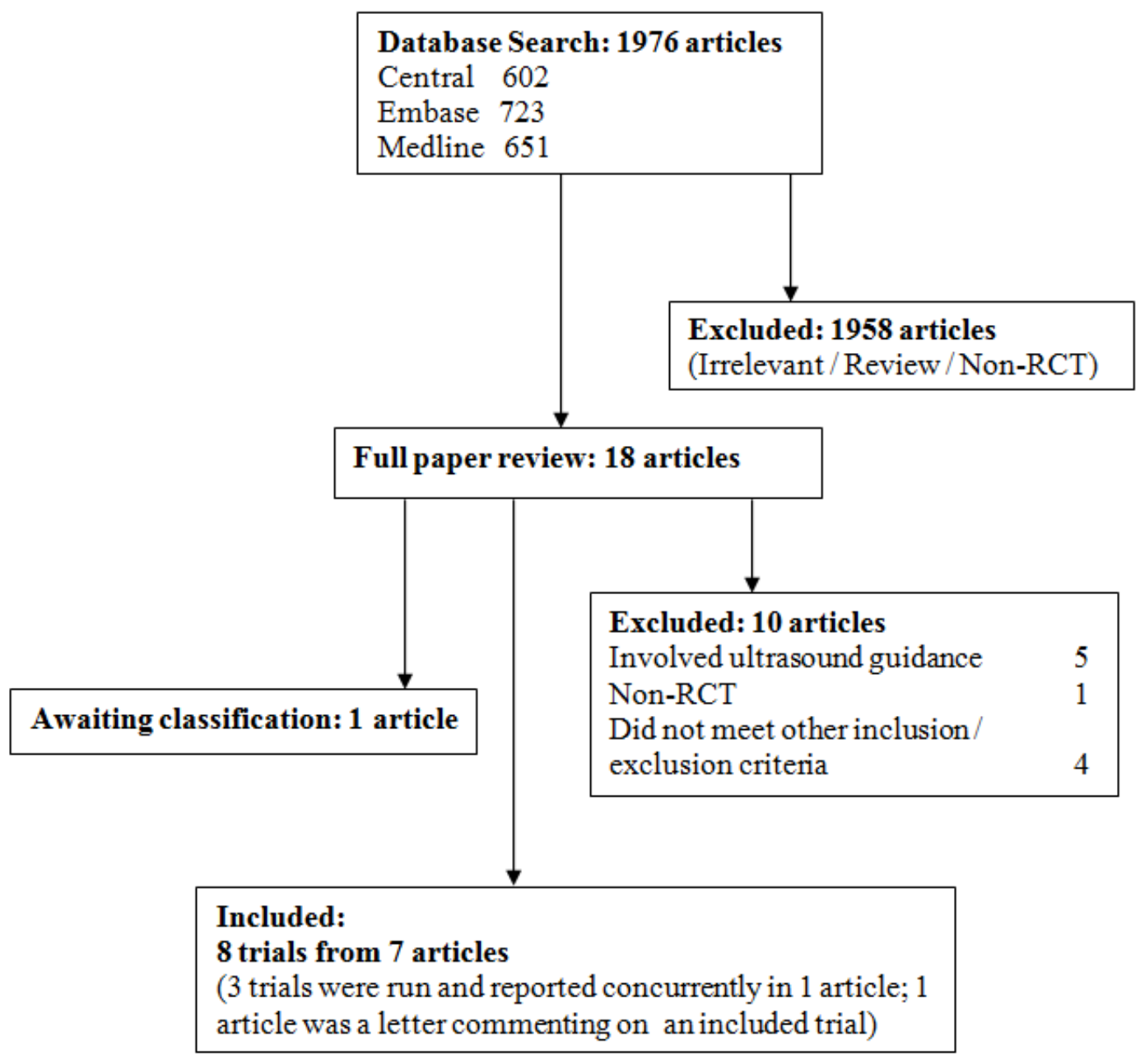

\section{Included studies}

We included a total of 20 trials in this update, eight of which were new. Details of individual trials are provided in the Characteristics of included studies table. All 20 included trials were reported in full. We obtained a translation for the only trial (Serradell Catalan 2001) not reported in the English language.

\section{Setting}

Each of the 20 trials took place in one of nine countries (Brazil: 1; Canada: 1; Denmark: 4; Finland: 2; Italy: 4; Spain: 3; Turkey: 1; UK: 2; USA: 2). All four Danish trials had the same lead investigator (Koscielniak-Nielsen) and shared many trial characteristics.
All four Italian trials also had the same lead investigator (Sia); three of these trials (Sia 2010a; Sia 2010b; Sia 2010c) were run concurrently and were published together.

\section{Participants}

The 20 trials included a total of 2098 participants; the number of participants in individual trials ranged from 50 (Inberg 1999; Pere 1993) to 138 (Sia 2010a; Sia 2010b; Sia 2010c). Fourteen patients were excluded after randomization because of the inability to locate the desired nerves in the three concurrent trials conducted by Sia (Sia 2010a; Sia 2010b; Sia 2010c); the distribution of these 14 patients between the three trials is not known. The 
percentage of male participants ranged from $2 \%$ to $75 \%$ in the 17 trials providing this information. The mean ages of trial participants, reported by 19 trials, ranged between 37 and 58 years; the inclusion of exclusively adult participants was confirmed in 10 trials providing age-range data or from their inclusion criteria. Eighteen trials reported the requirement for informed consent. Four trials (Baranowski 1990; Goldberg 1987; Inberg 1999; Lavoie 1992) gave no exclusion criteria relating to anaesthesia. Of the other 16 trials, nine trials excluded people with an American Society of Anaesthesiologists (ASA) score greater than two (Imbelloni 2005; K-Nielsen 1999a; K-Nielsen 1999b; Pere 1993; Sia 2001; Sia 2010a; Sia 2010b; Sia 2010c; Turkan 2002) and seven trials excluded people with an ASA score greater than three. The description of the types of surgery, including location or site and whether elective or acute, was generally limited in the trial reports but it was usually enhanced on receipt of further information from trialists. Details of the types or indications for surgery were given for 10 trials (Coventry 2001; Goldberg 1987; Imbelloni 2005; K-Nielsen 1997; K-Nielsen 1998; K-Nielsen 1999a; K-Nielsen 1999b; Sia 2010a; Sia 2010b; Sia 2010c), but only quantified in full in two (Coventry 2001; Goldberg 1987) and split by treatment group in only one trial (Coventry 2001). Surgery was explicitly restricted to the hand or wrist, or both, in five trials (Goldberg 1987; K-Nielsen 1997; Sia 2010a; Sia 2010b; Sia 2010c) and was probably limited to the same locations in Baranowski 1990. Seven trials also included forearm and elbow surgery (Inberg 1999; K-Nielsen 1998; K-Nielsen 1999a; K-Nielsen 1999b; Lavoie 1992; Pere 1993; Rodriguez 2008). While including forearm surgery, elbow surgery was not mentioned for Serradell Catalan 2001, Sia 2001, or Imbelloni 2005. There was no indication of location in Coventry 2001, although specific hand and wrist operations were listed. Surgery was referred to as 'elective' in three trials (Coventry 2001; K-Nielsen 1997; Sia 2001), 'scheduled' in another three trials (Baranowski 1990; Goldberg 1987; Inberg 1999); and 'post-traumatic' in Serradell Catalan 2001. Mixed elective and acute surgery were undertaken in three trials (K-Nielsen 1998; K-Nielsen 1999a; K-Nielsen

Table 1. Methods of nerve location 1999b) and, probably, also in Lavoie 1992. There was no information on the urgency of the operation in nine trials (Hickey 1993; Imbelloni 2005; Pere 1993; Rodriguez 2005; Rodriguez 2008; Sia 2010a; Sia 2010b; Sia 2010c; Turkan 2002).

\section{Interventions}

Thirteen trials (Coventry 2001; Imbelloni 2005; Inberg 1999; K-Nielsen 1997; K-Nielsen 1998; K-Nielsen 1999a; K-Nielsen 1999b; Pere 1993; Rodriguez 2008; Sia 2001; Sia 2010a; Sia 2010b; Sia 2010c) had two intervention groups. Four trials (Baranowski 1990; Goldberg 1987; Hickey 1993; Turkan 2002) had three intervention groups. Rodriguez 2005 had four intervention groups. The remaining two trials (Lavoie 1992; Serradell Catalan 2001) had five intervention groups. The trials made the following comparisons according to the aims of this review.

\section{Double versus single-injection technique}

Eight trials (Goldberg 1987; Hickey 1993; Inberg 1999; Lavoie 1992; Pere 1993; Rodriguez 2005; Serradell Catalan 2001; Turkan 2002) made this comparison.

\section{Multiple versus single-injection technique}

Seven trials (Baranowski 1990; K-Nielsen 1997; K-Nielsen 1999b; Lavoie 1992; Rodriguez 2005; Serradell Catalan 2001; Sia 2010a) made this comparison.

\section{Multiple versus double-injection technique}

Eleven trials (Coventry 2001; Imbelloni 2005; K-Nielsen 1998; K-Nielsen 1999a; Lavoie 1992; Rodriguez 2005; Rodriguez 2008; Serradell Catalan 2001; Sia 2001; Sia 2010b; Sia 2010c) made this comparison.

The method of nerve location varied among the studies (see Table 1) and can be broadly grouped into the following four methods: (1) transarterial (seven trials); (2) Winnie's perivascular (two trials); (3) paraesthesia (two trials); and (4) neurostimulation (17 trials).

\begin{tabular}{l|l|l}
\hline Method of nerve location & Number of injections & Trials \\
\hline $\begin{array}{l}\text { Transarterial } \\
\text { The axillary artery is palpated and deliber- } \\
\text { ately transfixed with a needle. The needle }\end{array}$ & Single - anterior & Hickey 1993 \\
$\begin{array}{l}\text { is then either withdrawn to inject LA an- } \\
\text { terior (superficial) to the artery, or inserted } \\
\text { deeper to inject LA posterior to the artery, } \\
\text { or both. }\end{array}$ & \\
\hline
\end{tabular}


Table 1. Methods of nerve location (Continued)

\begin{tabular}{|c|c|c|}
\hline & Single - posterior & Hickey 1993; K-Nielsen 1999b \\
\hline & Double & $\begin{array}{l}\text { Goldberg 1987; Hickey 1993; Imbelloni 2005; K-Nielsen } \\
\text { 1998; K-Nielsen 1999a; Pere } 1993\end{array}$ \\
\hline $\begin{array}{l}\text { Winnie's perivascular technique } \\
\text { A needle is inserted adjacent to the axil- } \\
\text { lary artery until a fascial click is felt, signi- } \\
\text { fying penetration of the neurovascular fas- } \\
\text { cial sheath. A catheter may be also inserted } \\
\text { proximally within the sheath. LA is then } \\
\text { injected, usually as a single bolus, while ap- } \\
\text { plying distal pressure to promote proximal } \\
\text { spread of the LA. }\end{array}$ & Single & Baranowski 1990; Turkan 2002 \\
\hline
\end{tabular}

\section{Paraesthesia}

Single

Goldberg 1987

A needle is inserted adjacent to the axillary artery and manipulated to elicit paraesthesia in the distribution of one or more of the four terminal nerves. LA is then injected at these locations.

\begin{tabular}{|c|c|}
\hline Single & Goldberg 1987 \\
\hline Multiple & Baranowski 1990 \\
\hline Single & $\begin{array}{l}\text { Inberg 1999; K-Nielsen 1997; Pere 1993; Rodriguez 2005; } \\
\text { Serradell Catalan 2001; Sia 2010a }\end{array}$ \\
\hline Double & $\begin{array}{l}\text { Coventry 2001; Inberg 1999; Lavoie 1992; Rodriguez 2005; } \\
\text { Rodriguez 2008; Serradell Catalan 2001; Sia 2001; Sia 2010b; } \\
\text { Sia 2010c }\end{array}$ \\
\hline Multiple & $\begin{array}{l}\text { Baranowski 1990; Coventry 2001; Imbelloni 2005; K-Nielsen } \\
\text { 1997; K-Nielsen 1998; K-Nielsen 1999a; K-Nielsen 1999b; } \\
\text { Lavoie 1992; Rodriguez 2005; Rodriguez 2008; Serradell } \\
\text { Catalan 2001; Sia 2001; Sia 2010a; Sia 2010b; Sia 2010c }\end{array}$ \\
\hline
\end{tabular}

\section{Neurostimulation (electrolocation)}

A needle is inserted adjacent to the axillary artery and manipulated until it comes into close proximity to one or more of the four terminal nerves. An electric current is passed through the needle and needlenerve proximity is signalled by an appropriate movement (motor response) of the forearm or hand, usually at currents of $\leq$ $0.5 \mathrm{~mA}$. LA is injected at these locations.

$\mathrm{LA}=$ local anaesthetic; $\mathrm{mA}=$ milliamperes.

\section{Outcomes}

We have documented the length of follow-up and the types of outcomes assessed in individual trials in the Characteristics of included studies table. Further details of the methods used to assess and define sensory and motor blockade are presented in Appendix 4.

With the exception of five trials (Lavoie 1992; Sia 2010a; Sia 2010b; Sia 2010c; Turkan 2002), the included trials provided separate data on anaesthesia outcomes (for example sensory blockade) for named individual nerves. We have not presented these data in this review because our focus is on overall measures of incomplete or inadequate anaesthesia.

Monitoring of longer-term effects (24 hours or over), particularly adverse effects, was conducted in 11 trials.

\section{Excluded studies}

Sixteen studies were excluded for reasons given in the Characteristics of excluded studies table; six of these were identi- 
fied in the first version of this review. Ten new trials were identified and excluded in this update for the following reasons: five studies because they involved ultrasound-guided techniques (Bloc 2010; Imasogie 2010; Liu 2005; Sites 2006; Yu 2007), two studies because they compared only single-injection techniques (Tuominen 1987; Youssef 1988), one study because it compared only multiple-injection techniques (Gianesello 2010), one study because it was non-randomized (Kjelstrup 2006), and one study because it involved only paediatric patients (Carre 2000).

\section{Risk of bias in included studies}

The risk of bias judgements on seven items for the individual trials are summarised in Figure 2 and Figure 3, and described in the risk of bias tables in Characteristics of included studies. We judged items as having a low, high, or 'unclear' risk of bias. An 'unclear' verdict often reflected a lack of information upon which to judge the item. Successful contact with trial investigators usually resulted in an improved assessment of one or more items. Lack of information on blinding, primarily assessor blinding, was always taken to imply that there was no blinding and was rated as high risk of bias. A high risk of bias rating was given for single items in six trials; this related to a lack of assessor blinding in four of these. 
Figure 2. Risk of bias summary: review authors' judgements about each risk of bias item for each included study.

\begin{tabular}{|c|c|c|c|c|c|c|c|}
\hline & 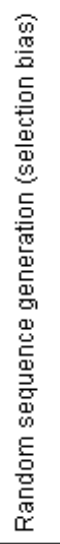 & 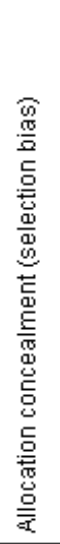 & 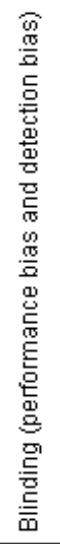 & 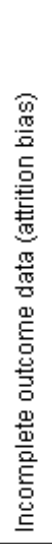 & 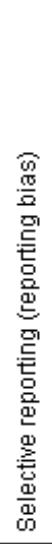 & 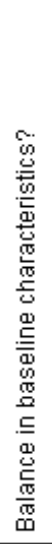 & 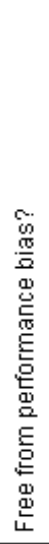 \\
\hline Baranowski 1990 & $?$ & $?$ & - & $\odot$ & $?$ & $?$ & 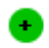 \\
\hline Coventry 2001 & $?$ & + & + & $\odot$ & $?$ & + & + \\
\hline Goldberg 1987 & $?$ & $?$ & 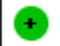 & $?$ & $?$ & $?$ & $?$ \\
\hline Hickey 1993 & $?$ & $?$ & - & $\odot$ & $?$ & $?$ & + \\
\hline Imbelloni 2005 & $?$ & $?$ & - & $?$ & $?$ & $?$ & $?$ \\
\hline Inberg 1999 & 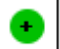 & $?$ & 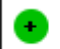 & $\odot$ & $?$ & $?$ & 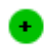 \\
\hline K-Nielsen 1997 & + & + & + & 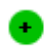 & + & $?$ & + \\
\hline K-Nielsen 1998 & $\odot$ & 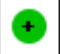 & + & $\odot$ & + & $?$ & + \\
\hline K-Nielsen 1999a & + & + & + & $\odot$ & + & $?$ & $?$ \\
\hline K-Nielsen 1999b & + & + & + & 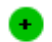 & + & $?$ & + \\
\hline Lavoie 1992 & + & $?$ & 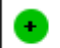 & $\odot$ & $?$ & 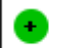 & + \\
\hline Pere 1993 & $?$ & $?$ & - & + & $?$ & $?$ & $?$ \\
\hline Rodriguez 2005 & + & $?$ & + & $\Theta$ & $?$ & $?$ & + \\
\hline Rodriguez 2008 & + & $?$ & 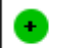 & $?$ & $?$ & $?$ & $?$ \\
\hline Serradell Catalan 2001 & + & $\Theta$ & + & + & $?$ & $?$ & + \\
\hline Sia 2001 & $?$ & $?$ & 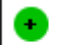 & $\odot$ & $?$ & $?$ & + \\
\hline Sia $2010 a$ & + & $?$ & + & $?$ & + & + & $?$ \\
\hline Sia 2010 b & + & $?$ & + & $?$ & + & + & $?$ \\
\hline Sia $2010 \mathrm{c}$ & + & $?$ & 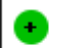 & $?$ & $\odot$ & + & $?$ \\
\hline Turkan 2002 & $?$ & $?$ & $?$ & $\odot$ & ? & $?$ & $?$ \\
\hline
\end{tabular}


Figure 3. Risk of bias graph: review authors' judgements about each risk of bias item presented as percentages across all included studies.

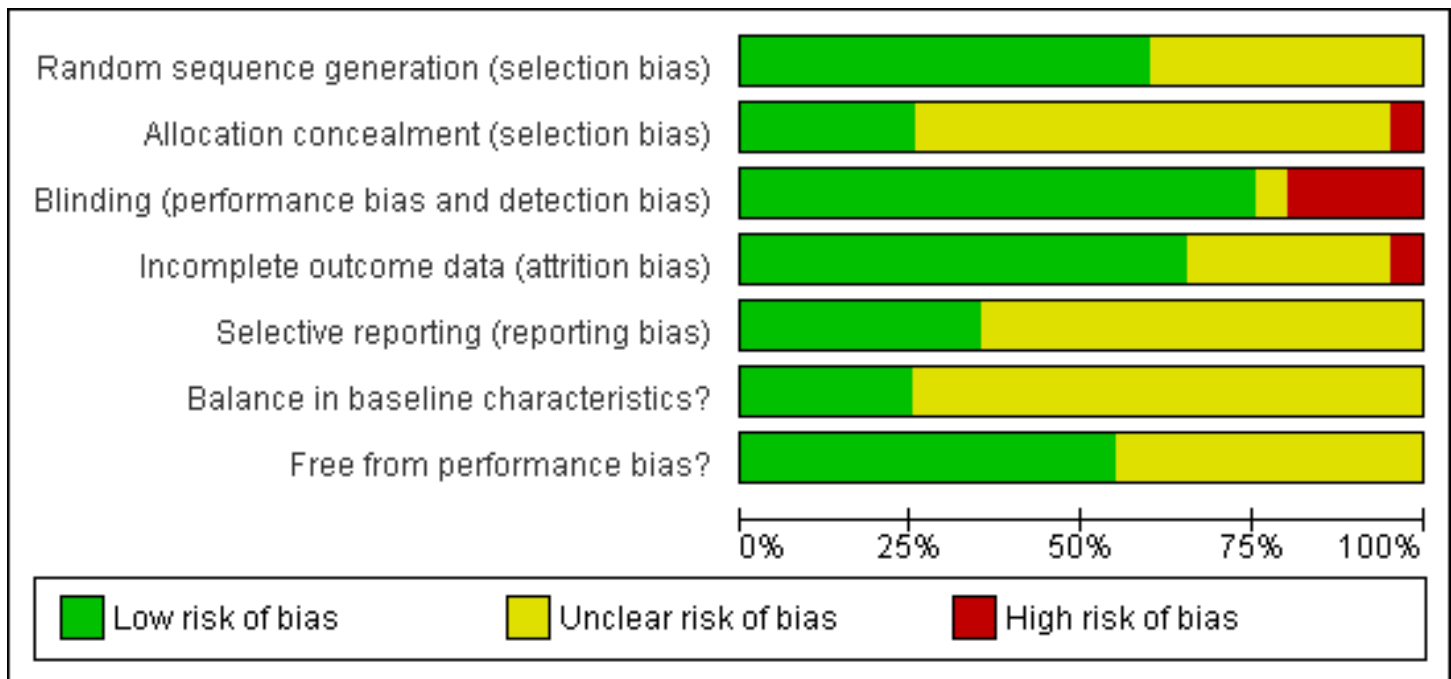

\section{Allocation}

There was a general lack of detail on the method of randomization and measures taken to conceal treatment allocation in the included trials. Only four trials (K-Nielsen 1997; K-Nielsen 1998; K-Nielsen 1999a; K-Nielsen 1999b) were judged at low risk of bias, resulting from adequate sequence generation and allocation concealment. Allocation was judged as concealed in Coventry 2001 but there were insufficient details on the shuffling of the envelopes to confirm the generation of an adequate randomization sequence. The use of an open randomization list by Serradell Catalan 2001 meant this trial was judged at high risk of selection bias.

\section{Blinding}

Assessor blinding for the primary outcome was not mentioned in four trials (Baranowski 1990; Hickey 1993; Imbelloni 2005; Pere 1993), which were thus judged at high risk of bias for this item; and was incomplete for Turkan 2002, which was judged as 'unclear' for this item. While safeguards were rarely described, the risk of bias was considered low for those trials that reported blinding.

\section{Incomplete outcome data}

The short follow-up in most of these trials prevented loss of followup for the primary outcome being a serious issue and we judged that all trials performed intention-to-treat analysis in that there was no cross over. 'Unclear' ratings generally resulted from postrandomization exclusions but we note also that none of the trials that followed up people after surgery explicitly reported that all trial participants attended their surgical follow-up. Unaddressed reporting inconsistencies in Rodriguez 2005 were the reason behind the high risk of bias judgement for this item in this trial.

\section{Selective reporting}

The lack of protocols or trial registration entries hampered the assessment of risk of bias from selective reporting. However, we judged that selective reporting bias was avoided by virtue of the consistent approach taken in the planning of two series of trials headed by Koscielniak-Nielsen (K-Nielsen 1997; K-Nielsen 1998; K-Nielsen 1999a; K-Nielsen 1999b) and Sia (Sia 2010a; Sia 2010b; Sia 2010c) and the provision of additional data on request.

\section{Other potential sources of bias}

Bias resulting from major imbalances in baseline characteristics was judged as low in five trials and 'unclear' in the remainder. Generally the lack of information on the distribution in the types

Single, double or multiple-injection techniques for axillary brachial plexus block for hand, wrist or forearm surgery in adults (Review) Copyright (C) 201 I The Cochrane Collaboration. Published by John Wiley \& Sons, Ltd. 
of surgery undertaken (and implicated nerves) in the intervention groups was the reason for uncertainty. The risk of performance bias, primarily based on an assessment of reported operator experience and comparability of this between intervention groups, was judged as low in 11 trials and 'unclear' in the rest. While we also based our judgement on an interpretation of individual trial procedures, we did not think the lack of reporting by trials on comparability of care programmes impacted on trial validity.

\section{Effects of interventions}

See: Summary of findings for the main comparison Double versus single-injection technique; Summary of findings 2 Multiple versus single-injection technique; Summary of findings 3 Multiple versus double-injection technique

The 20 included trials involved a total of 2098 participants who received regional anaesthesia for hand, wrist, forearm or elbow surgery.

Where data were available, we summed the results of the two or three intervention groups that fell into the same category (for example single injection) for the seven trials (Baranowski 1990; Goldberg 1987; Hickey 1993; Lavoie 1992; Rodriguez 2005; Serradell Catalan 2001; Turkan 2002) with more than two intervention groups. As stated a priori, we performed subgroup analysis according to the method of nerve location. We limited this to the outcome of primary analgesia failure and subgrouped according to whether nerves were located by nerve stimulation (or, more rarely, paraesthesia) or not, as in the transarterial method. Due to lack of data, we were unable to perform subgroup analyses according to the site of surgery. We were also unable to undertake sensitivity analyses to test aspects of trial methodology.

For primary analgesia or anaesthesia failure, we also presented data subgrouped according to whether this outcome was defined as incomplete overall sensory block, as determined by the individual trials, or incomplete sensory block as indicated by the need for supplementation at the surgical site.

\section{Double versus single-injection technique}

Eight trials (Goldberg 1987; Hickey 1993; Inberg 1999; Lavoie 1992; Pere 1993; Rodriguez 2005; Serradell Catalan 2001; Turkan 2002) made this comparison in a total of 498 participants. One person was excluded from Hickey 1993 following an aborted axillary block in which tachycardia and lightheadedness occurred during injection. The three incomplete procedures that occurred in the double-injection group of Rodriguez 2005 were included in an intention-to-treat analysis.

\section{Primary analgesia or anaesthesia failure}

The pooled results, using the random-effects model because of significant $(\mathrm{P}=0.02)$ and substantial $\left(\mathrm{I}^{2}=58 \%\right)$ heterogeneity, showed a statistically significant decrease in primary analgesia or anaesthesia failure (incomplete sensory block) in the double-injection group (see Figure 4) (RR 0.51, 95\% CI 0.30 to 0.85 ). Figure 4 also presents the results for the trials subgrouped according to the technique used for double injection (transarterial versus neurostimulation). The results of the four trials (Goldberg 1987; Hickey 1993; Pere 1993; Turkan 2002) using transarterial injection showed no statistically significant difference between the double and single-injection groups (failure: RR $0.72,95 \%$ CI 0.33 to 1.58 ), whereas a double injection was superior in those trials where location was by neurostimulation in both groups (failure: RR $0.40,95 \% 0.22$ to 0.73 ). A test of interaction based on fixedeffect risk ratios showed that the results of the two subgroups were statistically, significantly different from each other (two-tailed ztest $=0.0261$ ). However, this was not the case for the randomeffects model results (two-tailed z-test $=0.243$ ) and the results in the two subgroups were also heterogeneous, hence, the differences in the method of nerve location do not appear to explain fully the heterogeneity of the overall result. 
Figure 4. Forest plot of comparison: I Double versus single-injection technique, outcome: I.I Primary anaesthesia failure (incomplete sensory block).

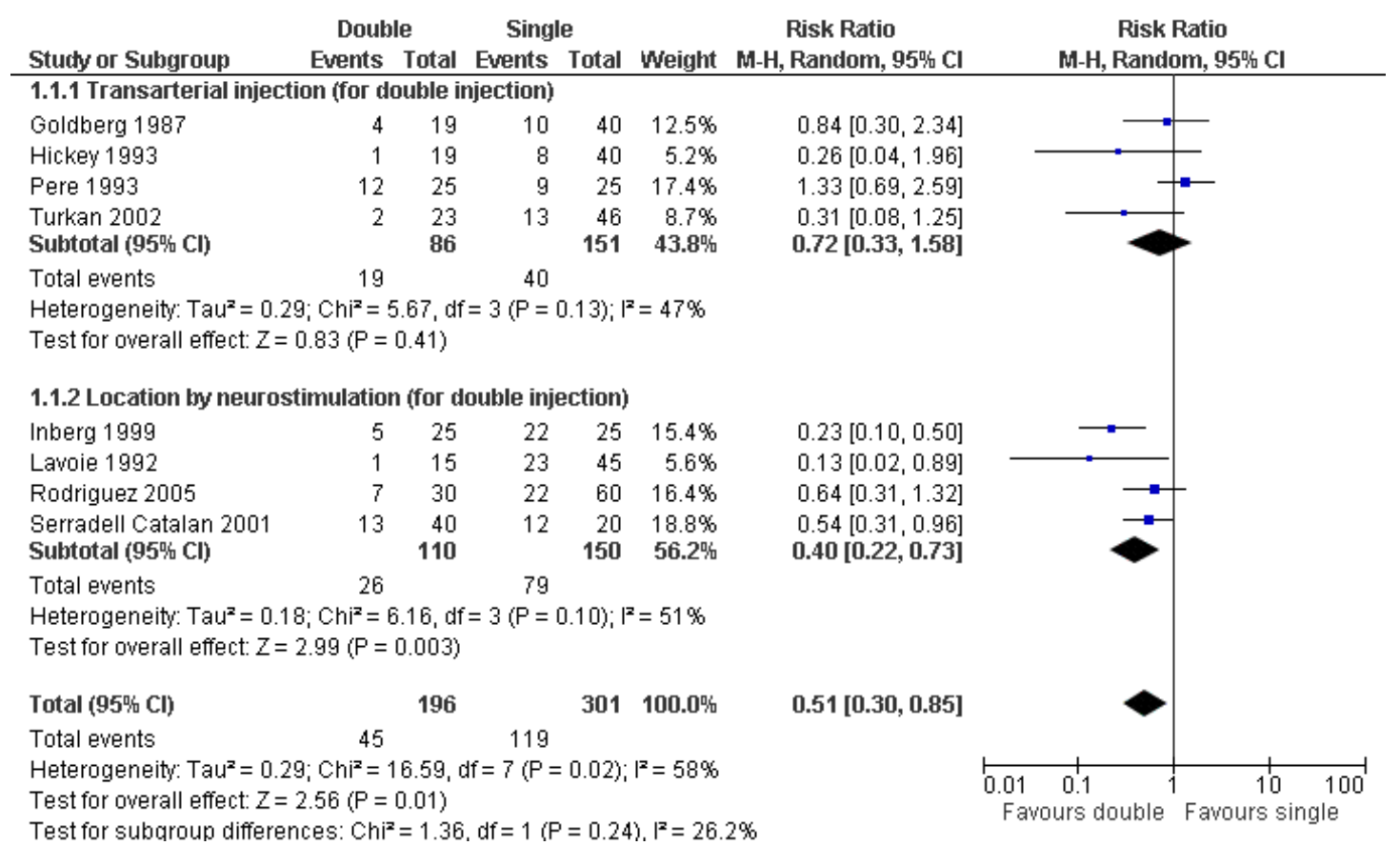

Analysis 1.2 presents the results subgrouped according to the definition of primary analgesia failure: incomplete overall sensory block (RR 0.43 , 95\% CI 0.24 to 0.76 ), or supplemental blocks required for surgical site (RR $0.43,95 \%$ CI 0.17 to 1.11 ). The results for Inberg 1999 illustrate the difference in these two definitions. In the first, complete anaesthesia (sensory block) is sought, and supplemental blocks are performed if necessary to achieve this. In the second, only anaesthesia of the anticipated surgical site is sought, and as a result, the extent of supplementation is generally less.

The plexus block failed totally in seven people, six of whom had general anaesthesia and one (in Inberg 1999) who had a new plexus block; there was no difference between the two groups in this outcome (see Analysis 1.3) (RR 1.29, 95\% CI 0.33 to 5.01). There was no statistically significant difference between the two injection groups in the numbers of participants with incomplete motor block (see Analysis 1.4) (RR 0.78, 95\% CI 0.0.58 to 1.03).

\section{Secondary analgesia failure, timing, complications and other outcomes}

None of the pooled differences between the two injection groups for secondary analgesia failure (surgical site pain, tourniquet pain or intra-operative sedation) were statistically significant (see Analysis 1.5). The only trial (Serradell Catalan 2001) reporting the time to perform the nerve block found that the double nerve block took significantly more time to perform (mean difference (MD) 1.65 minutes, $95 \%$ CI 0.72 to 2.58 minutes). None of the other differences in duration of operation, duration of tourniquet use and duration of block were statistically significant between the two groups (see Analysis 1.6). Four cases of venous puncture and six of paraesthesia occurred during nerve block in Serradell Catalan 2001; and one case of tachycardia and lightheadedness (signifying probable intravascular injection) in Hickey 1993. None of the differences between the two groups were statistically significant (see Analysis 1.7). The seven adverse effects, all lasting 24 hours, were all persistent paraesthesias in Serradell Catalan 2001 (see Analysis 1.8). The only persistent adverse effect, recorded at three months in Serradell Catalan 2001, that was noted in the 20 included trials was described as neurological dysfunction. This occurred in one participant of one of the two double-injection groups. Serradell Catalan 2001 found no statistically significant difference between the double and single-injection groups in patient discomfort or their dissatisfaction with the anaesthetic method (see Analysis 1.9).

\section{Multiple versus single-injection technique}

Seven trials (Baranowski 1990; K-Nielsen 1997; K-Nielsen 1999b; Lavoie 1992; Rodriguez 2005; Serradell Catalan 2001; Sia 2010a) made this comparison in a total of 634 participants. Two participants were excluded from K-Nielsen 1999b; one because of lack of 
comprehension of trial procedures and the other because of chest pain resulting in cancelled surgery. The one incomplete procedure that occurred in the multiple-injection group of Rodriguez 2005 was included in an intention-to-treat analysis.

\section{Primary analgesia or anaesthesia failure}

The pooled results, using the random-effects model because of significant $(\mathrm{P}=0.07)$ and substantial heterogeneity $\left(\mathrm{I}^{2}=49 \%\right)$, showed a statistically significant decrease in primary analgesia or anaesthesia failure (incomplete sensory block) in the multiple-in- jection group (see Figure 5) (RR 0.28, 95\% CI 0.16 to 0.48 ). Figure 5 also presents the trials subgrouped according to the technique used for single injection (neurostimulation versus no neurostimulation). The results of both groups of trials showed that multiple injections, all located via nerve stimulation, provided more complete sensory block than single injections located with (failure: RR $0.21,95 \%$ CI 0.09 to 0.48 ) or without (failure: RR $0.40,95 \%$ CI 0.25 to 0.65 ) the use of a nerve stimulator. A test of interaction showed that the results of the two subgroups were not statistically, significantly different from each other (two-tailed $\mathrm{z}$-test $=0.190)$.

Figure 5. Forest plot of comparison: 2 Multiple versus single-injection technique, outcome: 2.I Primary anaesthesia failure (incomplete sensory block).

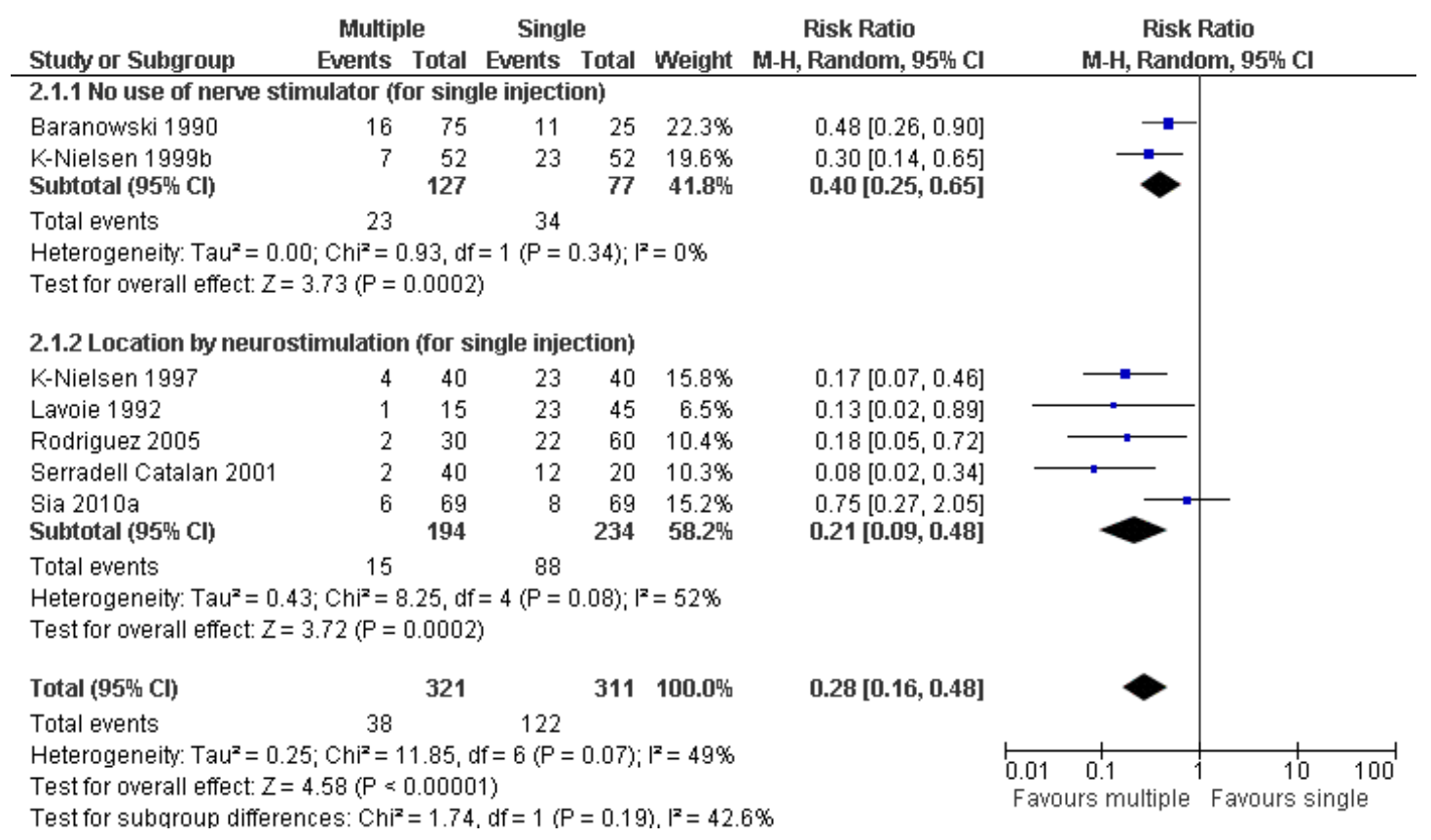

Analysis 2.2 shows the results subgrouped according to the definition of primary analgesia failure: incomplete overall sensory block (RR $0.28,95 \%$ CI 0.12 to 0.64 ), or supplemental blocks required for surgical site (RR 0.26 , 95\% CI 0.11 to 0.63 ). It should be noted that K-Nielsen 1997 was placed in the second category on the basis that it stipulated that supplementation of the musculocutaneous nerve was done only if necessary for surgery.

The plexus block failed totally in three people, all of whom then received general anaesthesia (see Analysis 2.3) (RR 0.44, 95\% CI 0.01 to 17.76). The pooled results for incomplete motor block, using the random-effects model because of significant $(P=0.03)$ and substantial heterogeneity $\left(\mathrm{I}^{2}=66 \%\right)$, showed a statistically significant increase in incomplete motor block in the single-injection group (see Analysis 2.4) (RR 0.61, 95\% CI 0.39 to 0.96).

Secondary analgesia failure, timing, complications and other outcomes

None of the pooled differences between the two injection groups for secondary analgesia failure (surgical site pain, tourniquet pain or intraoperative sedation) were statistically significant (see Analysis 2.5). Pooled analysis (using the random-effects model be- 
cause of significant heterogeneity) of the three trials (K-Nielsen 1997; Serradell Catalan 2001; Sia 2010a) reporting the time to perform the nerve block found that the multiple nerve block took significantly more time to perform (see Analysis 2.6) (mean difference (MD) 3.34 minutes, 95\% CI 2.66 to 4.03 minutes). There were conflicting findings in the two trials that measured the time from the start of the block until readiness for surgery (see Analysis 2.6). K-Nielsen 1997 found that this time period was significantly shorter in the multiple-injection group (MD - 13.50 minutes, 95\% CI -16.36 to - 10.64 minutes) whereas Sia 2010a found it to be significantly longer in the multiple-injection group (MD $6.80 \mathrm{~min}$ utes, $95 \%$ CI 4.53 to 9.07 minutes). None of the differences in duration of tourniquet use, duration of the block or length of surgery were statistically significant between the two groups (see Analysis 2.6). Using the random-effects model because of significant $(\mathrm{P}=0.01)$ and substantial heterogeneity $\left(\mathrm{I}^{2}=72 \%\right.$ and $69 \%$ respectively) for the pooled results for paraesthesia and tachycardia, Analysis 2.7 shows that none of the differences between the two groups in the six listed complications occurring during nerve block were statistically significant. However, the statistically significant excess of paraesthesia and tachycardia as well as the two serious episodes of local anaesthetic toxicity in the single injection group of K-Nielsen 1999b should not be disregarded given that these may reflect the method used for performing the single injection in this group (that is, transarterial). There appeared to be a trend for more arterial and venous punctures in the multiple-injection group (see Analysis 2.7). The three adverse effects, all lasting 24 hours, were all persistent paraesthesias in Serradell Catalan 2001 (see Analysis 2.8). Serradell Catalan 2001 found no statistically significant difference between the multiple and single- injection groups in patient discomfort. Pooled data from Serradell Catalan 2001 and Sia 2010a showed no statistically significant difference between the two groups in dissatisfaction with the anaesthetic method (see Analysis 2.9). K-Nielsen 1999b found no difference between the two groups in the pain experienced by the trial participants during performance of the block.

\section{Multiple versus double-injection technique}

Eleven trials (Coventry 2001; Imbelloni 2005; K-Nielsen 1998; K-Nielsen 1999a; Lavoie 1992; Rodriguez 2005; Rodriguez 2008; Serradell Catalan 2001; Sia 2001; Sia 2010b; Sia 2010c) made this comparison in a total of 937 participants. One participant of the multiple-injection group of K-Nielsen 1999a (who was taking cardiovascular medication) was excluded due to a severe reaction including loss of consciousness.

\section{Primary analgesia or anaesthesia failure}

The pooled results, using the fixed-effect model, showed a statistically significant decrease in primary analgesia or anaesthesia failure (incomplete sensory block) in the multiple-injection group (see Figure 6) (RR $0.28,95 \%$ CI 0.20 to 0.40 ). Figure 6 also presents the trials subgrouped according to the technique used for double injection (transarterial versus neurostimulation). The clearly similar results of both groups of trials showed that multiple injections, all located via neurostimulation, provided more complete sensory block than double injections located with (failure: RR 0.28, 95\% CI 0.18 to 0.44 ) or without (failure: RR $0.27,95 \%$ CI 0.15 to $0.49)$ the use of a nerve stimulator. 
Figure 6. Forest plot of comparison: 3 Multiple versus double-injection technique, outcome: 3.I Primary anaesthesia failure (incomplete sensory block).

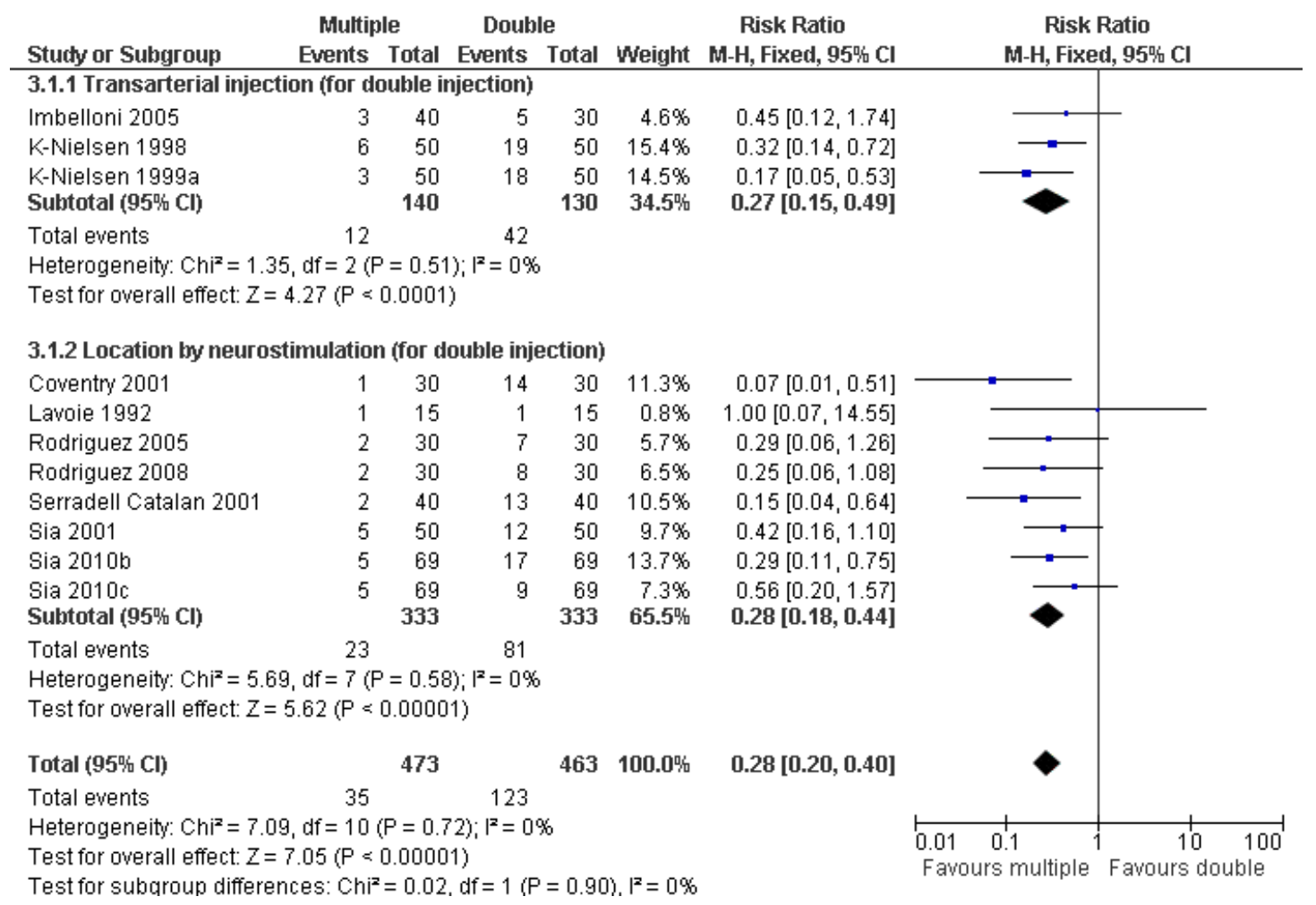

Analysis 3.2 shows the results subgrouped according to the definition of primary analgesia failure (incomplete overall sensory block or supplemental blocks required for surgical site). While the results for both groups were in favour of multiple injections (incomplete overall sensory block: RR $0.24,95 \%$ CI 0.15 to 0.37 ; supplemental blocks required for surgical site: RR $0.40,95 \%$ CI 0.24 to 0.66 ), it is noteworthy that there were proportionately fewer participants in the double-injection group with primary anaesthesia failure when this outcome was defined according to the need for supplemental blocks for the surgical area rather than incomplete overall sensory blockade.

Six people required general anaesthesia for block failure (see Analysis 3.3) (RR 0.24, 95\% CI 0.04 to 1.41). The pooled results for incomplete motor block, using the random-effects model because of significant $(\mathrm{P}=0.02)$ and substantial heterogeneity ( $\mathrm{I}^{2}$ $=62 \%$ ), showed a statistically significant decrease in incomplete motor block in the multiple-injection group (see Analysis 3.4) (RR $0.55,95 \%$ CI 0.36 to 0.85 ).

Secondary analgesia failure, timing, complications and other outcomes
There was a statistically significant decrease in tourniquet pain in the multiple-injection group (RR $0.53,95 \%$ CI 0.33 to 0.84 ) but not in the other outcomes of secondary analgesia failure (surgical site pain, and intraoperative sedation) although both favoured the multiple-injection group (see Analysis 3.5). Pooled results (using the random-effects model due to highly significant heterogeneity) from five trials (K-Nielsen 1998; Serradell Catalan 2001; Sia 2001; Sia 2010b; Sia 2010c) reporting the time to perform the nerve block found that the multiple-injection block took significantly more time to perform (see Analysis 3.6) (MD 1.74 minutes, 95\% CI 1.04 to 2.45 minutes). In contrast, the time from the start of the block until readiness for surgery was similar between the multipleinjection and double-injection groups (MD -0.06 minutes, 95\% CI -2.87 to 2.75 minutes) (see Analysis 3.6). Analysis 3.6 showed no statistically significant differences between the two groups for duration of tourniquet use, length of surgery or duration of block. Using the random-effects model because of significant $(P=0.01)$ and substantial heterogeneity $\left(\mathrm{I}^{2}=63 \%\right)$ in the pooled results for paraesthesia, Analysis 3.7 shows that there were no statistically significant differences between the two injection groups in the eight listed complications occurring during nerve block. It should be 
noted though that the greater incidence of tachycardia (resulting from intravascular injection) and axillary haematoma when the results of K-Nielsen 1998 and K-Nielsen 1999a were pooled are consistent with the method of double injection used (transarterial without neurostimulation). The six adverse effects, all lasting 24 hours, were all persistent paraesthesias in Serradell Catalan 2001 (see Analysis 3.8). The only persistent adverse effect, recorded at three months in Serradell Catalan 2001, was neurological dysfunction that occurred in one participant in one of the two doubleinjection groups. There was no statistically significant difference between the multiple and double-injection groups in patient discomfort or their dissatisfaction with the anaesthetic method (see Analysis 3.9). 


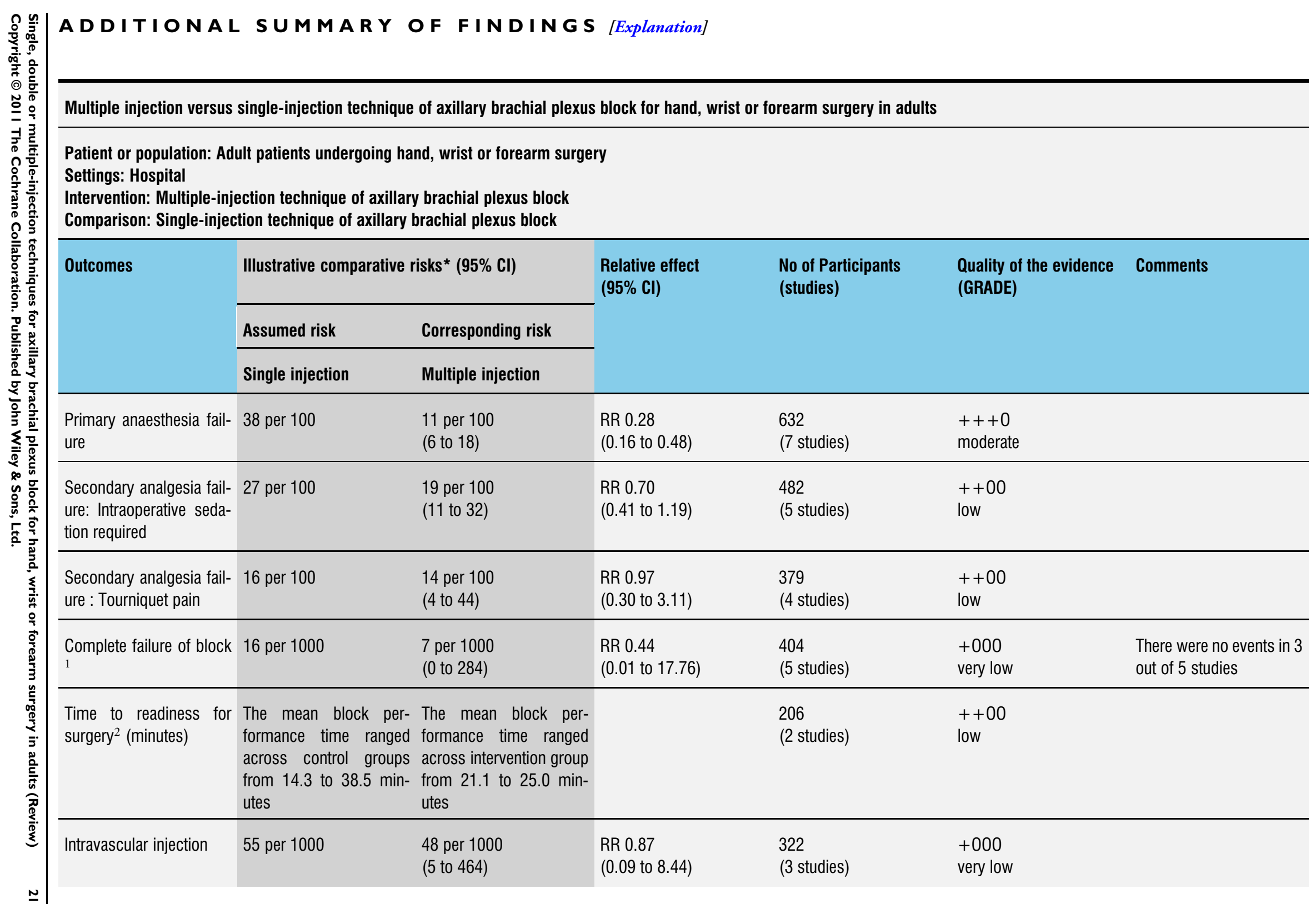




\begin{tabular}{lllll}
$\begin{array}{l}\text { Adverse effects lasting } 13 \text { per } 1000 \\
\text { more than } 24 \text { hours }{ }^{3}\end{array}$ & $\begin{array}{l}3 \text { per } 1000 \\
(0 \text { to } 34)\end{array}$ & RR $0.25(0.02$ to 2.59$)$ & $\begin{array}{l}244 \\
(3 \text { studies })\end{array}$ & $\begin{array}{l}\text { There were no events in } 2 \\
\text { very low }\end{array}$ \\
\hline
\end{tabular}

*The assumed risk for the 'control' group is based on the mean value of the results for all single-injection groups in the included trials reporting the outcome. The corresponding risk (and its $95 \%$ confidence interval) is based on the assumed risk in the comparison group and the relative effect of the intervention (and its $95 \% \mathrm{Cl}$ ).

Cl: Confidence interval; RR: Risk Ratio

GRADE Working Group grades of evidence

High quality: Further research is very unlikely to change our confidence in the estimate of effect.

Moderate quality: Further research is likely to have an important impact on our confidence in the estimate of effect and may change the estimate.

Low quality: Further research is very likely to have an important impact on our confidence in the estimate of effect and is likely to change the estimate.

Very low quality: We are very uncertain about the estimate.

1. Complete failure of block is defined as the need for general anaesthesia or a new plexus block to provide surgical anaesthesia.

2. Time to readiness for surgery is defined as the time required to perform the block plus the time from completion of the block to

development of surgical anaesthesia.

3. Adverse effects lasting more than 24 hours refers mainly to neurological symptoms or deficits in the arm that was blocked.

4. Fanelli 1999 observed a 1\% risk of transient neurological deficit in their study of 1650 patients receiving multiple-injection brachial

plexus blocks. 
Multiple-injection versus double-injection technique of axillary brachial plexus block for hand, wrist or forearm surgery in adults

Patient or population: Adult patients undergoing hand, wrist or forearm surgery

Settings: Hospital

Intervention: Multiple-injection technique of axillary brachial plexus block

Comparison: Double-injection technique of axillary brachial plexus block

\begin{tabular}{|c|c|c|c|c|c|c|}
\hline \multirow[t]{3}{*}{ Outcomes } & \multicolumn{2}{|c|}{ Illustrative comparative risks* $(95 \% \mathrm{Cl})$} & \multirow{3}{*}{$\begin{array}{l}\text { Relative effect } \\
(95 \% \mathrm{CI})\end{array}$} & \multirow{3}{*}{$\begin{array}{l}\text { No of Participants } \\
\text { (studies) }\end{array}$} & \multirow{3}{*}{$\begin{array}{l}\text { Quality of the evidence } \\
\text { (GRADE) }\end{array}$} & \multirow[t]{3}{*}{ Comments } \\
\hline & Assumed risk & Corresponding risk & & & & \\
\hline & Double injection & Multiple injection & & & & \\
\hline $\begin{array}{l}\text { Primary anaesthesia fail- } \\
\text { ure }\end{array}$ & 26 per 100 & $\begin{array}{l}7 \text { per } 100 \\
(5 \text { to } 10)\end{array}$ & $\begin{array}{l}\text { RR } 0.28 \\
(0.20 \text { to } 0.40)\end{array}$ & $\begin{array}{l}936 \\
\text { (11 studies) }\end{array}$ & $\begin{array}{l}+++0 \\
\text { moderate }\end{array}$ & \\
\hline $\begin{array}{l}\text { Secondary analgesia fail- } \\
\text { ure: Intraoperative seda- } \\
\text { tion required }\end{array}$ & 19 per 100 & $\begin{array}{l}15 \text { per } 100 \\
(11 \text { to } 20)\end{array}$ & $\begin{array}{l}\text { RR } 0.75 \\
(0.55 \text { to } 1.03)\end{array}$ & $\begin{array}{l}716 \\
\text { (7 studies) }\end{array}$ & $\begin{array}{l}++00 \\
\text { low }\end{array}$ & \\
\hline $\begin{array}{l}\text { Secondary analgesia fail- } \\
\text { ure : Tourniquet pain }\end{array}$ & 13 per 100 & $\begin{array}{l}7 \text { per } 100 \\
\text { (4 to } 11)\end{array}$ & $\begin{array}{l}\text { RR } 0.53 \\
(0.33 \text { to } 0.84)\end{array}$ & $\begin{array}{l}719 \\
\text { (7 studies) }\end{array}$ & $\begin{array}{l}+++0 \\
\text { moderate }\end{array}$ & \\
\hline $\begin{array}{l}\text { Complete failure of block } \\
1\end{array}$ & 23 per 1000 & $\begin{array}{l}6 \text { per } 1000 \\
\text { (1 to } 32)\end{array}$ & $\begin{array}{l}\text { RR } 0.24 \\
\text { (0.04 to 1.41) }\end{array}$ & $\begin{array}{l}600 \\
\text { (8 studies) }\end{array}$ & $\begin{array}{l}+000 \\
\text { very low }\end{array}$ & $\begin{array}{l}\text { There were no events in } 6 \\
\text { out of } 8 \text { studies. }\end{array}$ \\
\hline $\begin{array}{l}\text { Time to readiness for } \\
\text { surgery }^{2} \text { (minutes) }\end{array}$ & $\begin{array}{l}\text { The mean block per- } \\
\text { formance time ranged } \\
\text { across control groups } \\
\text { from } 8.8 \text { to } 38.0 \text { minutes }\end{array}$ & $\begin{array}{l}\text { The mean block per- } \\
\text { formance time ranged } \\
\text { across intervention group } \\
\text { from } 10.2 \text { to } 30 \text { minutes }\end{array}$ & & $\begin{array}{l}524 \\
\text { (5 studies) }\end{array}$ & $\begin{array}{l}++00 \\
\text { low }\end{array}$ & \\
\hline Intravascular injection & 66 per 1000 & $\begin{array}{l}36 \text { per } 1000 \\
(15 \text { to } 87)\end{array}$ & $\begin{array}{l}\text { RR } 0.55 \\
\text { (0.23 to } 1.32)\end{array}$ & $\begin{array}{l}476 \\
\text { (4 studies) }\end{array}$ & $\begin{array}{l}+000 \\
\text { very low }\end{array}$ & \\
\hline
\end{tabular}




\begin{tabular}{ll|lll}
\hline $\begin{array}{l}\text { Adverse effects lasting } 19 \text { per } 1000 \\
\text { more than } 24 \text { hours }^{3}\end{array}$ & $\begin{array}{l}4 \text { per } 1000 \\
(0 \text { to } 31)\end{array}$ & RR $0.20(0.02$ to 1.64$)$ & $\begin{array}{l}510 \\
(6 \text { studies })\end{array}$ & $\begin{array}{l}\text { There were no events in } 5 \\
\text { of the } 6 \text { studies. }\end{array}$ \\
\hline
\end{tabular}

*The assumed risk for the 'control' group is based on the mean value of the results for all double-injection groups in the included trials reporting the outcome. The corresponding risk (and its $95 \%$ confidence interval) is based on the assumed risk in the comparison group and the relative effect of the intervention (and its $95 \% \mathrm{Cl}$ ).

Cl: Confidence interval; RR: Risk Ratio

GRADE Working Group grades of evidence

High quality: Further research is very unlikely to change our confidence in the estimate of effect.

Moderate quality: Further research is likely to have an important impact on our confidence in the estimate of effect and may change the estimate.

Low quality: Further research is very likely to have an important impact on our confidence in the estimate of effect and is likely to change the estimate.

Very low quality: We are very uncertain about the estimate.

1. Complete failure of block is defined as the need for general anaesthesia or a new plexus block to provide surgical anaesthesia.

2. Time to readiness for surgery is defined as the time required to perform the block plus the time from completion of the block to

development of surgical anaesthesia.

3. Adverse effects lasting more than 24 hours refers mainly to neurological symptoms or deficits in the arm that was blocked.

4. Fanelli 1999 observed a 1\% risk of transient neurological deficit in their study of 1650 patients receiving multiple-injection brachial

plexus blocks. 


\section{DISCUSSION}

\section{Summary of main results}

The ideal regional anaesthetic technique should meet four criteria; it should be effective, fast, safe and cause the patient little or no pain. While all 20 included trials reported on anaesthetic effectiveness (primary anaesthesia), the reporting of timing (block performance time, onset time, time to readiness for surgery), safety (early and late complications), and pain during block performance was incomplete. Though the latter three criteria are described as secondary outcomes in this review, they are as important as the primary outcome of anaesthetic effectiveness when considering the choice of anaesthetic technique. We summarize the findings of the three comparisons in turn and then provide some overall comments.

\section{Double versus single-injection technique}

Primary anaesthesia failure was much less likely in the doubleinjection group than the single-injection group (RR 0.51, 95\% CI 0.30 to 0.85 ). This was true regardless of whether failure was defined as incomplete sensory block of all nerves or incomplete anaesthesia of the surgical site. However, when the data were subgrouped according to the technique used for double injection, double injections were significantly more effective than single injections only when neurostimulation was used in both intervention groups, and not when the transarterial technique was used. It should be noted that in the original review a test of interaction showed the results of these two subgroups to be significantly different from each other. This was not the case in the updated review (based on random-effects risk ratios) and, given that the method of nerve location by itself does not explain the heterogeneity within the two subgroups, we have therefore pooled the data and reported the summary statistic for all trials. There were no statistically significant differences between the double and single-injection groups in the other reported outcomes (incomplete motor block, secondary analgesia failure, timings, complications and patient discomfort).

\section{Multiple versus single-injection technique}

Primary anaesthesia failure was much less likely in the multipleinjection group than the single-injection group (RR 0.28, 95\% CI 0.16 to 0.48 ) and this held true across all subgroup analyses. Pooled data from four trials also showed a statistically significant decrease in incomplete motor block in the multiple-injection group. It took 3.3 minutes longer on average to perform the block in the multiple-injection group. However it is unclear if this has any impact on the time to readiness for surgery as the two trials that reported this outcome had conflicting results. There were no statistically significant overall differences in the other reported outcomes (secondary analgesia failure, other timings, complications and patient discomfort). In one study (K-Nielsen 1999b) there was a statistically significant excess of paraesthesia and tachycardia, and two serious episodes of local anaesthetic toxicity in the single-+injection group, which can be attributed to the transarterial technique used.

\section{Multiple versus double-injection technique}

Primary anaesthesia failure was much less likely in the multipleinjection group than the double-injection group (RR 0.28, 95\% CI 0.20 to 0.40 ); again, this held true across all subgroup analyses. In particular, it was irrespective of whether the double injections involved the transarterial injection technique or neurostimulation. Incomplete motor block and tourniquet pain were also significantly less likely in the multiple-injection group compared to the double-injection group. It took 1.7 minutes longer on average to perform the block in the multiple-injection group but the pooled data from five trials showed no overall difference in the time to readiness for surgery. There were no other statistically significant differences between the multiple and double-injection groups in the pooled results of other reported outcomes (secondary analgesia failure, other timings, complications and patient discomfort). The greater incidence of tachycardia (resulting from intravascular injections) and axillary haematoma when the results of K-Nielsen 1998 and K-Nielsen 1999a were pooled are likely to reflect the method of double injection used (transarterial without neurostimulation) in these trials.

\section{Overview}

The results of this update confirm the original review's conclusion that a multiple-injection technique (using neurostimulation) provides more effective anaesthesia than either a double or a singleinjection technique. The question of whether three or four injections should be performed, or which nerves should be targeted in the multiple injection technique, is not addressed in this review. The multiple-injection technique also appears to have other advantages, including more complete motor block and a reduced risk of tourniquet pain. Its primary disadvantage is that locating and injecting around three or more nerves in the axillary brachial plexus is much more complex, as reflected in the longer time required for performance of the multiple-injection technique compared to the single and double-injection techniques. Interestingly, this did not appear to significantly increase the time to readiness for surgery, although this is not necessarily conclusive given the limited data. The most likely explanation is that the increased anaesthetic efficacy of the multiple-injection technique offsets the longer block performance time.

The method of nerve location used in the single or double-injection techniques appears to influence the effectiveness and safety of anaesthesia. Double injections are more effective than single injections when neurostimulation is used in both interventions, but not when double injection is performed using the transarterial method and single injection is performed using neurostimulation. 
There was also some evidence of a greater risk of short-term complications related to vascular puncture, such as intravascular injection and axillary hematoma, when the transarterial method was used. Taken together, this suggests that neurostimulation should be the method of choice when performing a double-injection axillary block.

While there were no significant differences observed in many of the other outcomes related to secondary anaesthesia, complications and patient pain and discomfort, this cannot be regarded as conclusive due to the limited data. In particular, the safety of multiple-injection methods remains an important unresolved issue given the low complication event rates reported in this review. The inevitable increase in needle passes while searching for other nerves after the first or second injection carries an increased risk of vascular puncture and trauma to nerves that is difficult to quantify. However, one large, multicentre prospective study of multiple-injection techniques for upper and lower limb blockade found generally reassuring evidence for axillary brachial plexus block (Fanelli 1999). Although $17 \%$ (278/1650) of these multiple-injection axillary blocks elicited unintentional paraesthesiae prompting needle withdrawal, all $17(1 \%)$ people sustaining transient neurological dysfunction recovered fully at an average of six weeks. Fanelli et al (Fanelli 1999) also found some evidence that high tourniquet pressure rather than multiple injections was associated with neurological dysfunction.

\section{Overall completeness and applicability of evidence}

In this update we located an additional eight trials that met the inclusion criteria of the review, bringing the total to 20 trials. The number of participants in the updated review has doubled to more than 2000 participants, although the numbers of participants for each of the three comparisons are obviously fewer (ranging from 497 to 937). The distinction between no evidence of an effect and evidence of no effect still needs to be considered where there are apparently comparable findings. Application of trial results to clinical practice is hampered where there is an inadequate description of trial inclusion and exclusion criteria (six trials) and the types of surgery undertaken (10 trials). Another common shortcoming (nine trials) was the failure to monitor longer-term effects, particularly adverse effects.

\section{Quality of the evidence}

The quality of the evidence, appraised using the risk of bias assessment tool recommended by The Cochrane Collaboration (Higgins 2009), varied in the 20 trials but showed that the included trials were generally well conducted and either at low or unclear risk of bias for the seven aspects rated in our assessment (see Figure 3). Only six trials were rated at high risk of bias and this in one domain only for each trial. We consider that the findings of this review are therefore likely to be valid.

\section{Potential biases in the review process}

\section{Publication bias}

We may have missed trials that are not indexed in MEDLINE or EMBASE. In particular, we may have missed trials that remain unpublished in journals by not searching conference proceedings and other 'grey literature'. We did, however, approach trialists and contacts in the industry for information on existing trials. While the possibility of publication bias cannot be ruled out, we consider that a well-conducted trial on this topic would have stood a good chance of being published in specialist journals irrespective of its results. Our trial selection procedure was systematic and, after an initial filtering of the results from electronic searches, each author carried out independent selection.

\section{Pooling and heterogeneity}

We chose to pool data from trials testing the same comparisons; however, no two trials were identical. There were notable differences in the interventions (such as in the method of location of nerves and selection of specific nerves (see Table 1), study populations, and definitions of outcomes (see Appendix 4). We performed subgroup analyses of the outcome of primary anaesthesia failure according to the method of nerve location and the definition of adequate sensory blockade; however, the data were insufficient to examine the effects of the other methodological differences.

\section{AUTHORS' CONCLUSIONS}

\section{Implications for practice}

This review provides evidence that multiple-injection techniques using neurostimulation for axillary plexus block provide more effective anaesthesia than either double or single-injection techniques. There is insufficient evidence to determine the relative effects of single, double and multiple-injection techniques on the incidence of complications, secondary analgesia failure, patient discomfort and pain during the procedure. There is some evidence suggesting a greater risk of complications and less satisfactory anaesthesia with methods using the transarterial approach rather than neurostimulation.

\section{Implications for research}

Since the original review was published, the use of ultrasound to guide peripheral nerve blockade has become widespread and has 
largely supplanted neurostimulation techniques, particularly in developed countries with access to the technology. Hence while the maintenance of this review in the light of any new evidence from randomized trials is required, we do not consider that conducting further randomized trials on this subject is a priority. We however suggest that the systematic surveillance of people undergoing these injections to ascertain adverse effects, in particular serious and permanent neurological injuries, should be ongoing.

\section{ACKNOWLEDGEMENTS}

For this review update, we continue to be grateful for the help received for previous versions from the people listed in the previous acknowledgements (Handoll 2006). We would like to acknowledge the contribution to the first version made by Zbigniew J Koscielniak-Nielsen, which we have drawn upon in this version.

We are very grateful to Karen Hovhannisyan for developing and running the search strategies for this update, and to Jane Cracknell for her continued support and patience. We thank Dr Salvatore Sia for responding to our request for further details on his three trials published in 2010 .

\section{R E F E R E N C E S}

\section{References to studies included in this review}

Baranowski 1990 \{published data only\}

Baranowski AP, Pither CE. A comparison of three methods of axillary brachial plexus anaesthesia. Anaesthesia 1990;45 (5):362-5. [MEDLINE: 1990289904]

Coventry 2001 \{published data only\} Coventry DM. Personal communication October 132004. * Coventry DM, Barker KF, Thomson M. Comparison of two neurostimulation techniques for axillary brachial plexus block. British Journal of Anaesthesia 2001;86(1):80-3. [MEDLINE: 21459214]

Goldberg 1987 \{published data only\} Goldberg ME, Gregg C, Larijani GE, Norris MC, Marr AT, Seltzer JL. A comparison of three methods of axillary approach to brachial plexus blockade for upper extremity surgery. Anesthesiology 1987;66(6):814-6. [MEDLINE: 1987239468]

Hickey 1993 \{published data only\} Hickey R, Hoffman J, Tingle LJ, Rogers JN, Ramamurthy $\mathrm{S}$, Hickey R, et al.Comparison of the clinical efficacy of three perivascular techniques for axillary brachial plexus block. Regional Anesthesia 1993;18(6):335-8.

Imbelloni 2005 \{published data only\}

Geier KO. Radiological evaluation of the spread of different local anesthetic volumes during posterior brachial plexus block. Revista Brasileira de Anestesiologia 2006;56(2): 202-3. [MEDLINE: 19468641]

* Imbelloni LE, Beato L, Cordeiro JA. Comparison of transarterial and multiple nerve stimulation techniques for axillary block using lidocaine with epinephrine. Revista Brasileira de Anestesiologia 2005;55(1):40-9. [MEDLINE: 19471807]

Inberg 1999 \{published and unpublished data\}

Annila P. Personal communication December 212004.

* Inberg P, Annila I, Annila P. Double-injection method using peripheral nerve stimulator is superior to single injection in axillary plexus block. Regional Anesthesia and Pain Medicine 1999;24(6):509-13. [MEDLINE: 20053774]

K-Nielsen 1997 \{published data only\}

Koscielniak-Nielsen ZJ. Axillary block of the brachial plexus by single, double or multiple injection techniques [dissertation]. Copenhagen: University of Copenhagen, 2000.

Koscielniak-Nielsen ZJ. Personal communication November 112004.

${ }^{*}$ Koscielniak-Nielsen ZJ, Stens-Pedersen HL, Lippert FK. Readiness for surgery after axillary block: single or multiple injection techniques. European Journal of Anaesthesiology 1997;14(2):164-71. [MEDLINE: 1997244004]

K-Nielsen 1998 \{published and unpublished data\} Koscielniak-Nielsen ZJ. Axillary block of the brachial plexus by single, double or multiple injection techniques [dissertation]. Copenhagen: University of Copenhagen, 2000.

Koscielniak-Nielsen ZJ. Personal communication November 152004.

* Koscielniak-Nielsen ZJ, Hesselbjerg L, Fejlberg V.

Comparison of transarterial and multiple nerve stimulation techniques for an initial axillary block by $45 \mathrm{~mL}$ of mepivacaine $1 \%$ with adrenaline. Acta Anaesthesiologica Scandinavica 1998;42(5):570-5. [MEDLINE: 1998266411]

K-Nielsen 1999a \{published and unpublished data\} Koscielniak-Nielsen ZJ. Axillary block of the brachial plexus by single, double or multiple injection techniques [dissertation]. Copenhagen: University of Copenhagen, 2000.

Koscielniak-Nielsen ZJ. Personal communication December 22004.

* Koscielniak-Nielsen ZJ, Nielsen PR, Nielsen SL, Gardi-T, Hermann C. Comparison of transarterial and multiple nerve stimulation techniques for axillary block using a high dose of mepivacaine with adrenaline. Acta Anaesthesiologica Scandinavica 1999;43(4):398-404. [MEDLINE: 1999241583]

K-Nielsen 1999b \{published and unpublished data\} Coleman MM, Day F. Axillary blockade by the targeted method. Added benefit?. Canadian Journal of Anaesthesia 
2000;47(2):192-3. [MEDLINE: 10674519]

Koscielniak-Nielsen ZJ. Axillary block of the brachial plexus

by single, double or multiple injection techniques [dissertation].

Copenhagen: University of Copenhagen, 2000.

Koscielniak-Nielsen ZJ. Personal communication December 142004.

* Koscielniak-Nielsen ZJ, Rotboll Nielsen P, Sorensen T, Stenor M. Low dose axillary block by targeted injections of the terminal nerves. Canadian Journal of Anaesthesia 1999; 46(7):658-64. [MEDLINE: 99369591]

Lavoie 1992 \{published and unpublished data\} Lang SA. Axillary block [letter; comment]. Canadian Journal of Anaesthesia 1992;39(10):1118-9.

* Lavoie J, Martin R, Tétrault JP, Coté DJ, Colas MJ. Axillary plexus block using a peripheral nerve stimulator: single or multiple injections. Canadian Journal of Anaesthesia 1992;39(6):583-6. [MEDLINE: 1992354096] Martin R. Personal communication January 52005.

Pere 1993 \{published and unpublished data\}

Pere P. Personal communication February 2005.

* Pere P, Pitkanen M, Tuominen M, Edgren J, Rosenberg $\mathrm{PH}$. Clinical and radiological comparison of perivascular and transarterial techniques of axillary brachial plexus block. British Journal of Anaesthesia 1993;70(3):276-9. [MEDLINE: 1993229180]

Rodriguez 2005 \{published data only\} Rodriguez J, Taboada M, Del Rio S, Barcena M, Alvarez J. A comparison of four stimulation patterns in axillary block. Regional Anesthesia and Pain Medicine 2005;30(4):324-8. [MEDLINE: 16032582]

Rodriguez 2008 \{published data only\} Rodriguez J, Taboada M, Oliveira J, Ulloa B, Bascuas $\mathrm{B}$, Alvarez J, et al.Radial plus musculocutaneous nerve stimulation for axillary block is inferior to triple nerve stimulation with $2 \%$ mepivacaine. Journal of Clinical Anesthesia 2008;20(4):253-6. [MEDLINE: 18617121]

Serradell Catalan 2001 \{published and unpublished data\} Serradell Catalan A. Personal communication February 3 2005.

* Serradell Catalan A, Moncho Rodriguez JM, Santos Carnes JA, Herrero Carbo R, Villanueva Ferrer JA, Masdeu Castellvi J. Axillary brachial plexus anesthesia. How many nerve stimulation responses do we look for? [Anestesia de plexo braquial por via axilar. Cuantas respuestas buscamos con neuroestimulacion?]. Revista Espanola de Anestesiologia y Reanimacion 2001;48(8):356-63. [MEDLINE: 21533027]

Sia 2001 \{published data only\}

Sia S, Lepri A, Ponzecchi P. Axillary brachial plexus block using peripheral nerve stimulator: a comparison between double- and triple-injection techniques. Regional Anesthesia and Pain Medicine 2001;26(6):499-503. [MEDLINE: 21564506]

Sia 2010a \{published data only\}

Sia S, Lepri A, Marchi M. Axillary block by "selective" injections at the nerves involved in surgery using a peripheral nerve stimulator: a comparison with a "standard" triple- injection technique. Regional Anesthesia and Pain Medicine 2010;35(1):22-7. [MEDLINE: 20052813]

Sia 2010b \{published data only\}

Sia S, Lepri A, Marchi M. Axillary block by "selective" injections at the nerves involved in surgery using a peripheral nerve stimulator: a comparison with a "standard" tripleinjection technique. Regional Anesthesia and Pain Medicine 2010;35(1):22-7. [MEDLINE: 20052813]

Sia 2010c \{published data only\}

Sia S, Lepri A, Marchi M. Axillary block by "selective" injections at the nerves involved in surgery using a peripheral nerve stimulator: a comparison with a "standard" tripleinjection technique. Regional Anesthesia and Pain Medicine 2010;35(1):22-7. [MEDLINE: 20052813]

Turkan 2002 \{published data only\}

Turkan H, Baykal B, Ozisik T. Axillary brachial plexus blockade: an evaluation of three techniques. Military Medicine 2002;167(9):723-5. [: 0026-4075]

\section{References to studies excluded from this review}

\section{Bloc 2010 \{published data only\}}

Bloc S, Mercadal L, Garnier T, Komly B, Leclerc P, Morel B, et al.Comfort of the patient during axillary blocks placement: a randomized comparison of the neurostimulation and the ultrasound guidance techniques. European Journal of Anaesthesiology 2010;27(7):628-33.

\section{Bouaziz 1997 \{published data only\}}

Bouaziz H, Narchi P, Mercier FJ, Labaille T, Zerrouk N, Girod J, et al.Comparison between conventional axillary block and a new approach at the midhumeral level. Anesthesia \& Analgesia 1997;84(5):1058. [: PubMed: 9141931]

\section{Carre 2000 \{published data only\}}

Carre P, Joly A, Cluzel Field B, Wodey E, Lucas MM, Ecoffey C. Axillary block in children: single or multiple injection?. Paediatric Anaesthesia 2000;10(1):35-9.

Gianesello 2010 \{published data only\}

Gianesello L, Pavoni V, Coppini R, Buoninsegni LT, Gori $\mathrm{G}$, Mori E, et al.Comfort and satisfaction during axillary brachial plexus block in trauma patients: comparison of techniques. Journal of Clinical Anesthesia 2010;22(1):7-12.

Imasogie 2010 \{published data only\}

Imasogie N, Ganapathy S, Singh S, Armstrong K, Armstrong P. A prospective, randomized, double-blind comparison of ultrasound-guided axillary brachial plexus blocks using 2 versus 4 injections. Anesthesia \& Analgesia 2010;110(4):1222-6

\section{K-Nielsen 2000 \{published data only\}}

Koscielniak-Nielsen ZJ, Rotboll Nielsen P, Risby Mortensen C. A comparison of coracoid and axillary approaches to the brachial plexus. Acta Anaesthesiologica Scandinavica 2000; 44(3):274-9.

Kjelstrup 2006 \{published data only\}

Kjelstrup T, Kjelstrup T. Transarterial block as an addition to a conventional catheter technique improves the axillary 
block. Acta Anaesthesiologica Scandinavica 2006;50(1): 112-6. [MEDLINE: 16451159]

Liu 2005 \{published data only\}

Liu FC, Liou JT, Tsai YF, Li AH, Day YY, Hui YL, et al.Efficacy of ultrasound-guided axillary brachial plexus block: a comparative study with nerve stimulator-guided method. Chang Gung Medical Journal 2005;28(6):396-402. [MEDLINE: 16124155]

\section{Sia 2001b \{published data only\}}

Sia S, Bartoli M. Selective ulnar nerve localization is not essential for axillary brachial plexus block using a multiple nerve stimulation technique. Regional Anesthesia and Pain Medicine 2001;26(1):12-6. [MEDLINE: 11172505]

Singelyn 1992 \{published data only\}

Singelyn FJ, Dangoisse M, Bartholomee S, Gouverneur JM. Adding clonidine to mepivacaine prolongs the duration of anesthesia and analgesia after axillary brachial plexus block. Regional Anesthesia 1992;17(3):148-50. [MEDLINE: 1606097]

Sites 2006 \{published data only\}

Sites BD, Beach ML, Spence BC, Wiley CW, Shiffrin J, Hartman GS, et al.Ultrasound guidance improves the success rate of a perivascular axillary plexus block. Acta Anaesthesiologica Scandinavica 2006;50(6):678-84.

Tuominen 1987 \{published data only\}

Tuominen MK, Pitkänen MT, Numminen MK, Rosenberg PH. Quality of axillary brachial plexus block. Comparison of success rate using perivascular and nerve stimulator techniques. Anaesthesia 1987;42(1):20-2.

\section{Vester-Andersen 1984 \{published data only\}}

Vester-Andersen T, Husum B, Lindeburg T, Borrits L, Gothgen I. Perivascular axillary block V: blockade following $60 \mathrm{ml}$ of mepivacaine $1 \%$ injected as a bolus or as 30 + $30 \mathrm{ml}$ with a 20-min interval. Acta Anaesthesiologica Scandinavica 1984;28(6):612-6. [MEDLINE: 85118112]

Vester-Andersen 1986 \{published data only\} Vester-Andersen T, Husum B, Zaric D, Eriksen C. Perivascular axillary block VII: the effect of a supplementary dose of $20 \mathrm{ml}$ mepivacaine $1 \%$ with adrenaline to patients with incomplete sensory blockade. Acta Anaesthesiologica Scandinavica 1986;30(3):231-4. [MEDLINE: 1986292011]

Youssef 1988 \{published data only\} Youssef MS, Desgrand DA. Comparison of two methods of axillary brachial plexus anaesthesia. British Journal of Anaesthesia 1988;60(7):841-4.

\section{Yu 2007 \{published data only\}}

Yu W-P, Xu X-Z, Wu D-Z, Guo X-Y, Huang P-T. Efficacy of axillary approach brachial plexus blocking by ultrasoundguided four points via one-puncture technique. National Medical Journal of China 2007;87(11):740-5. [MEDLINE: 17565841]

\section{References to studies awaiting assessment}

\section{Ramirez-Gomez 2010 \{published data only\}}

Ramirez-Gomez M, Schlufter-Stolberg R, Resendiz-Vargas S. Axillary brachial plexus block. Single or multiple neurostimulation response. [Bloque del plexo braquial via axilar. Respuesta única o múltiple por neuroestimulación]. Revista Mexicana De Anestesiologia 2010;33(1):9-16.

\section{Additional references}

\section{Altman 2003}

Altman DG, Bland JM. Interaction revisited: the difference between two estimates. BMJ 2003;326:219.

\section{Burnham 1958}

Burnham PJ. Regional block of the great nerves of the upper arm. Anesthesiology 1958;19:281-4.

\section{Coventry 2001a}

Coventry DM, Barker KF, Thomson M. Comparison of two neurostimulation techniques for axillary brachial plexus block. British Journal of Anaesthesia 2001;86(1):80-3. [MEDLINE: 21459214]

De Jong 1961

De Jong RH. Axillary block of the brachial plexus. Anesthesiology 1961;22:215-25.

\section{Fanelli 1999}

Fanelli G, Casati A, Garancini P, Torri G. Nerve stimulator and multiple injection technique for upper and lower limb blockade: failure rate, patient acceptance, and neurologic complications. Anesthesia \& Analgesia 1999;88(4):847-52.

\section{Geier 2006}

Geier KO. Radiological evaluation of the spread of different local anesthetic volumes during posterior brachial plexus block. Revista Brasileira de Anestesiologia 2006;56(2): 202-3.

Higgins 2003

Higgins JPT, Thompson SG, Deeks JJ, Altman DG. Measuring inconsistency in meta-analyses. BMJ 2003;327 (7414):557-60.

Higgins 2009

Higgins JPT, Green S, editors. Chapter 8: Assessing risk of bias in included studies. table 8.5a. The Cochrane Collaboration's tool for assessing risk of bias. Cochrane Handbook for Systematic Reviews of Interventions Version 5.1 (updated March 2011). The Cochrane Collaboration, 2008. Available from www.cochrane-handbook.org.

\section{K-Nielsen 1997a}

Koscielniak-Nielsen ZJ, Stens-Pedersen HL, Lippert KF. Readiness for surgery after axillary block: single or multiple injection techniques. European Journal of Anaesthesiology 1997;14(2):164-71. [MEDLINE: 1997244004]

\section{K-Nielsen 1998a}

Koscielniak-Nielsen ZJ, Hesselbjerg L, Fejlberg V. Comparison of transarterial and multiple nerve stimulation techniques for an initial axillary block by $45 \mathrm{ml}$ of mepivacaine $1 \%$ with adrenaline. Acta Anaesthesiologica Scandinavica 1998;42(5):570-5. 


\section{K-Nielsen 1999c}

Koscielniak-Nielsen ZJ, Nielsen PR, Nielsen SL, Gardi T, Hermann C. Comparison of transarterial and multiple nerve stimulation techniques for axillary block using a high dose of mepivacaine with adrenaline. Acta Anaesthesiologica Scandinavica 1999;43(4):398-404. [MEDLINE: 1999241583]

\section{Lassale 1984}

Lassale B, Ang ET. Particularités de l'organisation du tissus celluleux de la cavité axillaire. Bulletin. Societe de Chirurgie de Paris 1984;9:57-60.

\section{Lavoie 1992a}

Lavoie J, Martin R, Tétrault JP, Coté DJ, Colas MJ. Axillary plexus block using a peripheral nerve stimulator: single or multiple injections. Canadian Journal of Anaesthesia 1992; 39(6):583-6. [MEDLINE: 1992354096]

\section{Partridge 1987}

Partridge BL, Katz J, Benirschke K. Functional anatomy of the brachial plexus sheath: Implications for anesthesia. Anesthesiology 1987;66:743-7.

\section{RevMan 5.1}

The Nordic Cochrane Centre, The Cochrane Collaboration. Review Manager (RevMan). 5.1. Copenhagen: The Nordic Cochrane Centre, The Cochrane Collaboration, 2011.

\section{Sia 2001a}

Sia S, Lepri A, Ponzecchi P. Axillary brachial plexus block using peripheral nerve stimulator: a comparison between double- and triple-injection techniques. Regional Anesthesia and Pain Medicine 2001;26(6):499-503. [MEDLINE: 21564506]

\section{Stan 1995}

Stan TC, Krantz MA, Solomon DL, Poulos JG, Chaouki $\mathrm{K}$. The incidence of neurovascular complications following axillary brachial plexus block using a transarterial approach.
A prospective study of 1000 consecutive patients. Regional Anesthesia 1995;20:486-92.

\section{Thompson 1983}

Thompson GE, Rorie DK. Functional anatomy of the brachial plexus sheaths. Anesthesiology 1983;59:117-22.

\section{Urban 1994}

Urban MK, Urquhart B. Evaluation of brachial plexus anesthesia for upper extremity surgery. Regional Anesthesia 1994;19:175-82.

\section{Vester-Andersen 1984a}

Vester-Andersen T, Eriksen C, Christiansen C. Perivascular axillary block III: blockade following $40 \mathrm{ml}$ of $0.5 \%, 1 \%$ or $1.5 \%$ mepivacaine with adrenaline. Acta Anaesthesiologica Scandinavica 1984;28(1):95-8. [MEDLINE: 84175125]

\section{Vester-Andersen 1984b}

Vester-Andersen T, Husum B, Lindeburg T, Borrits L, Gøthgen I. Perivascular axillary block IV: blockade following 40, 50 , or $60 \mathrm{ml}$ mepivacaine $1 \%$ with adrenaline. Acta Anaesthesiologica Scandinavica 1984;28(1):99-105. [MEDLINE: 84175126]

\section{Vester-Andersen 1986a}

Vester-Andersen T, Broby-Johansen U, Bro-Rasmussen F. Perivascular axillary block VI: the distribution of gelatine solutions injected into the axillary neurovascular sheath of cadavers. Acta Anaesthesiologica Scandinavica 1986;30(1): 18-22. [MEDLINE: 1986182646]

\section{References to other published versions of this review}

\section{Handoll 2006}

Handoll HHG, Koscielniak-Nielsen ZJ. Single, double or multiple injection techniques for axillary brachial plexus block for hand, wrist or forearm surgery. Cochrane Database of Systematic Reviews 2006, Issue 1. [DOI: 10.1002/ 14651858.CD003842.pub2]

* Indicates the major publication for the study 
CHARACTERISTICS OF STUDIES

Characteristics of included studies [ordered by study ID]

Baranowski 1990

\begin{tabular}{|c|c|}
\hline Methods & $\begin{array}{l}\text { Method of randomization: not stated. } \\
\text { No blinding indicated. } \\
\text { No loss to follow-up. }\end{array}$ \\
\hline Participants & $\begin{array}{l}\text { London, UK } \\
\text { Period of study: not stated. } \\
100 \text { people scheduled for outpatient hand surgery. Informed consent. } \\
\text { Male: not stated; mean age: } 49 \text { years. } \\
\text { Excluded: no details. }\end{array}$ \\
\hline Interventions & $\begin{array}{l}\text { Multiple (neurostimulation method) versus multiple (paraesthesia method) versus single } \\
\text { injection. } \\
\text { All received local anaesthetic (LA solution): up to } 40 \mathrm{ml} \text { lignocaine } 1.5 \% \text { with adrenaline } \\
200 \mu \mathrm{g} \text {. } \\
\text { No premedication. No sedation or IV analgesia. All blocks performed or supervised by } \\
1 \text { of the } 2 \text { trial authors. } \\
\text { 1. Multiple injection using neurostimulator: unsheathed block needle. Attempts made to } \\
\text { locate } 3 \text { to } 4 \text { main branches of brachial plexus; nerve specific muscle twitches. Incremental } \\
\text { LA injections. } \\
\text { 2. Multiple injection using paraesthesia: } 22 \text { gauge regional block needle. Attempts made } \\
\text { to locate } 3 \text { to } 4 \text { main peripheral nerves. Incremental LA injections. Distal pressure } \\
\text { applied. } \\
3 \text {. Single injection via catheter on its insertion (introduction with } 18 \text { gauge needle) in } \\
\text { brachial plexus sheath. Fascial 'click' and easy insertion used to identify sheath. Distal } \\
\text { pressure applied. }\end{array}$ \\
\hline Outcomes & $\begin{array}{l}\text { Length of follow-up: } 30 \text { minutes } \\
\text { Sensory blockade } \\
\text { Motor blockade (no data) } \\
\text { Anaesthesia failure (less than } 3 \text { nerves fully blocked, general anaesthesia, failure to pen- } \\
\text { etrate brachial plexus sheath) }\end{array}$ \\
\hline
\end{tabular}

Notes

Request for details of methods, types of surgery and results, including adverse effects, sent to Dr Baranowski on 02/12/04.

Risk of bias

\begin{tabular}{lll}
\hline Bias & Authors' judgement & Support for judgement \\
\hline $\begin{array}{l}\text { Random sequence generation (selection } \\
\text { bias) }\end{array}$ & Unclear risk & $\begin{array}{l}\text { "One hundred patients ... were randomly } \\
\text { allocated”. No details of method. }\end{array}$ \\
\hline Allocation concealment (selection bias) & Unclear risk & No details of method.
\end{tabular}




\section{Baranowski 1990 (Continued)}

\begin{tabular}{|c|c|c|}
\hline $\begin{array}{l}\text { Blinding (performance bias and detection } \\
\text { bias) } \\
\text { All outcomes }\end{array}$ & High risk & No mention of blinding. \\
\hline $\begin{array}{l}\text { Incomplete outcome data (attrition bias) } \\
\text { All outcomes }\end{array}$ & Low risk & No loss to follow-up seemed likely. \\
\hline Selective reporting (reporting bias) & Unclear risk & Possible but no protocol available. \\
\hline Balance in baseline characteristics? & Unclear risk & $\begin{array}{l}\text { Incomplete information to judge: no gen- } \\
\text { der or type of surgery. Single injection } \\
\text { group was } 6 \text { years younger (not statistically } \\
\text { significant). }\end{array}$ \\
\hline Free from performance bias? & Low risk & $\begin{array}{l}\text { "All of the blocks were performed or su- } \\
\text { pervised by one of the two authors." There } \\
\text { were a register and a consultant. Other } \\
\text { treatment (none) seemed comparable. }\end{array}$ \\
\hline
\end{tabular}

\section{Coventry 2001}

\begin{tabular}{|c|c|}
\hline Methods & $\begin{array}{l}\text { Method of randomization: "Technique written on card and placed in envelope. Envelopes } \\
\text { sealed, shuffled and numbered 1-60." "Envelope opened immediately pre-op by 'regional } \\
\text { anaesthetist"'. } \\
\text { Double-blind: anaesthetist carrying out assessments and surgeon were blind to injection } \\
\text { technique. } \\
\text { Blinded outcome assessor. } \\
\text { No loss to follow-up. }\end{array}$ \\
\hline Participants & $\begin{array}{l}\text { Dundee, UK } \\
\text { Period of study: } 1995 \text {. } \\
60 \text { people undergoing elective upper limb surgery: Dupuytren's, carpal tunnel, tendon } \\
\text { surgery, arthrodesis/arthroplasty, wrist arthroscopy and miscellaneous. } \\
\text { Male: } 45 \% \text {; age range: } 20 \text { to } 85 \text { years. } \\
\text { Excluded: patients refusing a local anaesthetic technique, dementia; age }<17 \text { years; pe- } \\
\text { ripheral neuropathy, sensitivity to amide local anaesthetics; ASA physical status }>3 \text { (see } \\
\text { notes). }\end{array}$ \\
\hline Interventions & $\begin{array}{l}\text { Multiple versus double injection (both groups using the neurostimulation method). } \\
\text { All received LA solution: } 30 \mathrm{ml} \text { lidocaine } 15 \mathrm{mg} / \mathrm{ml} \text { with epinephrine } 5 \mathrm{ug} / \mathrm{ml} \text {. Nerve } \\
\text { blockade facilitated using } 22 \mathrm{G} \text { insulated short-bevelled needle and peripheral nerve } \\
\text { stimulator. All blocks carried out by one operator. } \\
\text { Initial sedation with midazolam. Skin anaesthetised with } 1 \text { to } 2 \mathrm{ml} \text { plain lidocaine } 10 \\
\mathrm{mg} / \mathrm{ml} \text {. Musculocutaneous nerve was first located and } 5 \mathrm{ml} \mathrm{LA} \mathrm{solution} \mathrm{injected.} \\
\text { 1. Multiple injection: } 15 \mathrm{ml} \mathrm{LA} \text { to median nerve followed by } 10 \mathrm{ml} \mathrm{LA} \text { to radial nerve. } \\
\text { 2. Double injection: single injection of } 25 \mathrm{ml} \mathrm{LA} \mathrm{to} \mathrm{median} \mathrm{nerve.}\end{array}$ \\
\hline
\end{tabular}




\section{Coventry 2001 (Continued)}

\begin{tabular}{l|l}
\hline Outcomes & $\begin{array}{l}\text { Length of follow-up: } 30 \text { minutes (and duration of surgery) } \\
\text { Sensory blockade } \\
\text { Motor blockade } \\
\text { Analgesic failure (use of supplementary anaesthesia) } \\
\text { Duration of surgery } \\
\text { Tourniquet discomfort } \\
\text { Problems (all nerves located; no problems indicated) }\end{array}$ \\
\hline Notes & $\begin{array}{l}\text { Reply to request for details of methods and adverse effects received from Dr Coventry } \\
\text { on } 13 / 10 / 04 .\end{array}$ \\
& $\begin{array}{l}\text { The ASA (American Society of Anesthesiologists) physical status classification is a system } \\
\text { for assessing the fitness of patients before surgery. It has five categories }(1-5): 1=\text { healthy, } \\
2=\text { mild systemic disease, } 3=\text { severe systemic disease, } 4=\text { severe disease that is a constant } \\
\text { threat to life, } 5=\text { moribund. }\end{array}$ \\
\hline
\end{tabular}

\section{Risk of bias}

\begin{tabular}{|c|c|c|}
\hline Bias & Authors' judgement & Support for judgement \\
\hline $\begin{array}{l}\text { Random sequence generation (selection } \\
\text { bias) }\end{array}$ & Unclear risk & $\begin{array}{l}\text { "randomly allocated" "Technique written } \\
\text { on card and placed in envelope. Envelopes } \\
\text { sealed, shuffled and numbered 1-60." Un- } \\
\text { clear how well shuffled. }\end{array}$ \\
\hline Allocation concealment (selection bias) & Low risk & $\begin{array}{l}\text { Sealed "Envelope opened immediately pre- } \\
\text { op by 'regional anaesthetist". }\end{array}$ \\
\hline $\begin{array}{l}\text { Blinding (performance bias and detection } \\
\text { bias) } \\
\text { All outcomes }\end{array}$ & Low risk & $\begin{array}{l}\text { Double-blind. Blinded investigator anaes- } \\
\text { thetist then carried out all assessments. This } \\
\text { investigator was totally blind as was the sur- } \\
\text { geon. No assessment was carried out by the } \\
\text { regional anaesthetists thus ensuring blind- } \\
\text { ing. }\end{array}$ \\
\hline $\begin{array}{l}\text { Incomplete outcome data (attrition bias) } \\
\text { All outcomes }\end{array}$ & Low risk & No loss to follow-up. \\
\hline Selective reporting (reporting bias) & Unclear risk & $\begin{array}{l}\text { Likely but no protocol available and took } \\
6 \text { years to publish. }\end{array}$ \\
\hline Balance in baseline characteristics? & Low risk & $\begin{array}{l}\text { Baseline characteristics including types of } \\
\text { surgery detailed and appeared balanced. }\end{array}$ \\
\hline Free from performance bias? & Low risk & $\begin{array}{l}\text { All blocks carried out by one operator. No } \\
\text { cause for concern. }\end{array}$ \\
\hline
\end{tabular}


Goldberg 1987

\begin{tabular}{ll}
\hline Methods & $\begin{array}{l}\text { Method of randomization: not stated. } \\
\text { Blinded outcome assessor: operating surgeon } \\
\text { No loss to follow-up. }\end{array}$ \\
\hline Participants & $\begin{array}{l}\text { Philadelphia, USA } \\
\text { Period of study: not stated. } \\
59 \text { people scheduled for upper extremity surgery, wrist or more distal, amenable to } \\
\text { brachial plexus block outpatient hand surgery: carpal tunnel repair/median nerve release; } \\
\text { Dupuytren's contracture release; arthroplasty of interphalangeal joint; ganglion excision; } \\
\text { distal radial and/or ulnar plating; foreign body excision; miscellaneous finger operations. } \\
\text { Consenting. } \\
\text { Male: not stated; mean age: } 50 \text { years, age } 18+\text { years. } \\
\text { Excluded: no details. }\end{array}$ \\
\hline
\end{tabular}

Interventions

Double versus single (neurostimulation method) versus single (paraesthesia method) injection.

All received local anaesthetic (LA) solution: $40 \mathrm{ml} / 70 \mathrm{~kg}$ mepivacaine $1.5 \%$.

No mention of premedication, sedation or IV analgesia. All blocks performed by first or second year anaesthesiology residents supervised by staff anaesthesiologist (usually first author).

1. Double transarterial injection: 22 gauge short bevel needle inserted transarterial fixation - half of LA volume administered posterior to axillary artery and half anterior to artery.

2. Single injection using nerve stimulator: 23 gauge insulated needle connected to stimulator. Whole volume of LA injected when maximum stimulation no longer produced muscle activity.

3. Single injection using paraesthesia: 22 gauge short bevel needle inserted until hand paraesthesia elicited - whole volume of LA injected.

\begin{tabular}{ll}
\hline Outcomes & Length of follow-up: hand clinic (timing not specified) \\
Sensory blockade \\
Anaesthesia failure (non-blocked nerves) \\
Adverse effects (none at hand clinic) \\
\hline
\end{tabular}

Notes

Request for details of methods, types of surgery and results, including adverse effects, sent to Prof Goldberg on 15/12/04.

\section{Risk of bias}

\begin{tabular}{|c|c|c|}
\hline Bias & Authors' judgement & Support for judgement \\
\hline $\begin{array}{l}\text { Random sequence generation (selection } \\
\text { bias) }\end{array}$ & Unclear risk & $\begin{array}{l}\text { "Three methods of blockade were ran- } \\
\text { domly selected." No details of method. }\end{array}$ \\
\hline Allocation concealment (selection bias) & Unclear risk & No details of method. \\
\hline $\begin{array}{l}\text { Blinding (performance bias and detection } \\
\text { bias) } \\
\text { All outcomes }\end{array}$ & Low risk & $\begin{array}{l}\text { Pain was tested "by a surgeon (with an Allis } \\
\text { clamp) unaware of the method utilized." }\end{array}$ \\
\hline
\end{tabular}


Goldberg 1987 (Continued)

\begin{tabular}{l|l|l}
\hline $\begin{array}{l}\text { Incomplete outcome data (attrition bias) } \\
\text { All outcomes }\end{array}$ & Unclear risk & No mention of loss to follow-up. \\
\hline Selective reporting (reporting bias) & Unclear risk & Possible but no protocol available. \\
\hline Balance in baseline characteristics? & Unclear risk & $\begin{array}{l}\text { Incomplete information to judge: no gen- } \\
\text { der or type of surgery. Single injection } \\
\text { groups were } 6 \text { and 11 years younger than } \\
\text { transarterial groups. }\end{array}$ \\
\hline Free from performance bias? & Unclear risk & $\begin{array}{l}\text { No difference in "the level of training of the } \\
\text { residents who performed the blocks, which } \\
\text { ranged from 1-19 months". No other prob- } \\
\text { lems detected - blinded surgeon. }\end{array}$ \\
\hline
\end{tabular}

\section{Hickey 1993}

\begin{tabular}{|c|c|}
\hline Methods & $\begin{array}{l}\text { Method of randomization: not specified. } \\
\text { No blinding of patient, care-giver or outcome assessor described. } \\
\text { No loss to follow-up. }\end{array}$ \\
\hline Participants & $\begin{array}{l}\text { Texas, USA. } \\
\text { Period of study: not stated. } \\
60 \text { adults scheduled for surgery of the upper extremity (not otherwise specified). } \\
\text { Male: } 1.7 \% \text {; mean age } 56 \text { years. } \\
\text { Excluded: ASA physical status> } 3 \text { (see notes). }\end{array}$ \\
\hline Interventions & $\begin{array}{l}\text { Double versus single posterior versus single anterior injection (transarterial method in } \\
\text { all groups). } \\
\text { All received local anaesthetic (LA) solution: } 1.5 \% \text { mepivacaine with } 5 \mathrm{mcg} / \mathrm{ml} \\
\text { epinephrine; total volume } 50 \mathrm{ml} \text {. Transarterial technique in all cases with a } 22 \mathrm{G} \text { short- } \\
\text { bevel block needle. All blocks performed by residents supervised by one staff anaesthe- } \\
\text { siologist. } \\
\text { Sedative premedication with IV midazolam: up to } 3 \mathrm{mg} \\
\text { 1. Double injection: injection of half of LA volume }(25 \mathrm{ml}) \text { anterior to axillary artery, } \\
\text { injection of other half }(25 \mathrm{ml}) \text { posterior to axillary artery. } \\
\text { 2. Single posterior injection: injection of all of LA volume }(50 \mathrm{ml}) \text { posterior to axillary } \\
\text { artery. } \\
\text { 3. Single anterior injection: injection of all of LA volume }(50 \mathrm{ml}) \text { anterior to axillary } \\
\text { artery. } \\
\text { Subcutaneous injection of } 3 \mathrm{ml} \text { of LA over the axillary artery to block the intercosto- } \\
\text { brachial nerve. }\end{array}$ \\
\hline Outcomes & $\begin{array}{l}\text { Length of follow-up: } 30 \text { minutes } \\
\text { Sensory blockade } \\
\text { Motor blockade } \\
\text { Analgesic failure (use of supplementary anaesthesia; general anaesthesia) } \\
\text { Onset of analgesia and anaesthesia in individual nerve territories }\end{array}$ \\
\hline
\end{tabular}


Hickey 1993 (Continued)

Complications during block injection and operation

\begin{tabular}{ll}
\hline Notes & One double injection patient excluded from the analyses because of an aborted block. \\
The ASA (American Society of Anesthesiologists) physical status classification is a system \\
for assessing the fitness of patients before surgery. It has five categories $(1-5): 1=$ healthy, \\
$2=$ mild systemic disease, $3=$ severe systemic disease, $4=$ severe disease that is a constant \\
threat to life, $5=$ moribund.
\end{tabular}

Risk of bias

\begin{tabular}{|c|c|c|}
\hline Bias & Authors' judgement & Support for judgement \\
\hline $\begin{array}{l}\text { Random sequence generation (selection } \\
\text { bias) }\end{array}$ & Unclear risk & "Randomized study". No further details. \\
\hline Allocation concealment (selection bias) & Unclear risk & No details on allocation concealment. \\
\hline $\begin{array}{l}\text { Blinding (performance bias and detection } \\
\text { bias) } \\
\text { All outcomes }\end{array}$ & High risk & $\begin{array}{l}\text { No blinding stated (seems unlikely given } \\
\text { the supervisory aspect). }\end{array}$ \\
\hline $\begin{array}{l}\text { Incomplete outcome data (attrition bias) } \\
\text { All outcomes }\end{array}$ & Low risk & All participants accounted for. \\
\hline Selective reporting (reporting bias) & Unclear risk & $\begin{array}{l}\text { No protocol. Insufficient information to } \\
\text { judge this. }\end{array}$ \\
\hline Balance in baseline characteristics? & Unclear risk & $\begin{array}{l}\text { Insufficient information to judge this in } \\
\text { terms of lack of details on surgical interven- } \\
\text { tions. Double injection group on average } 8 \\
\text { years older. }\end{array}$ \\
\hline Free from performance bias? & Low risk & $\begin{array}{l}\text { All blocks performed by residents directly } \\
\text { supervised by the same member of staff. }\end{array}$ \\
\hline
\end{tabular}

\section{Imbelloni 2005}

\begin{tabular}{|c|c|}
\hline Methods & $\begin{array}{l}\text { Method of randomization: not stated. } \\
\text { No blinding of patient, care-giver or outcome assessor described. } \\
\text { No loss to follow-up. }\end{array}$ \\
\hline Participants & $\begin{array}{l}\text { Sao Jose do Rio Preto, Brazil } \\
\text { Period of study: not stated. } \\
70 \text { adults scheduled for orthopedic surgery of the forearm and hand. Informed consent. } \\
\text { Male: } 56 \% \text {; mean age } 38 \text { years. } \\
\text { Exclusions: ASA physical status }>2 \text { (see notes), Age }<20 \text { years or }>60 \text { years. }\end{array}$ \\
\hline
\end{tabular}




\begin{tabular}{|c|c|}
\hline Interventions & $\begin{array}{l}\text { Multiple (neurostimulation method) versus double injection (transarterial method). } \\
\text { All received local anaesthetic (LA) solution: } 1.6 \% \text { lidocaine with } 5 \mathrm{mcg} / \mathrm{ml} \text { epinephrine; } \\
\text { total volume } 50 \mathrm{ml} \text {. The identity and experience level of the operator performing the } \\
\text { blocks was not stated. } \\
\text { No premedication given. } \\
\text { 1. Multiple injection: neurostimulation-guided, injection of } 20 \mathrm{ml} \text { to ulnar or distal } \\
\text { radial nerve response, } 20 \mathrm{ml} \text { to median nerve, } 10 \mathrm{ml} \text { to musculocutaneous nerve. } \\
\text { 2. Double injection: transarterial technique, injection of } 30 \mathrm{ml} \text { posterior to axillary artery, } \\
\text { injection of } 20 \mathrm{ml} \text { anterior to artery. } \\
\text { Incomplete blocks were supplemented but the definition of incomplete blocks and the } \\
\text { timing of supplementation were not specified. }\end{array}$ \\
\hline Outcomes & $\begin{array}{l}\text { Length of follow-up: sensory and motor block follow-up duration was not specified. } \\
\text { Patients were followed up for } 48 \text { hours postoperatively to assess for complications. } \\
\text { Sensory blockade } \\
\text { Analgesic failure (use of supplementary anaesthesia; general anaesthesia, pain at surgical } \\
\text { site) } \\
\text { Time to readiness for surgery } \\
\text { Tourniquet discomfort and pain } \\
\text { Complications during block injection and operation, and up to } 48 \text { hours after } \\
\text { Block duration } \\
\text { Patient satisfaction }\end{array}$ \\
\hline Notes & $\begin{array}{l}\text { Block outcomes were vaguely defined, and assessment timing not specified. } \\
\text { The ASA (American Society of Anesthesiologists) physical status classification is a system } \\
\text { for assessing the fitness of patients before surgery. It has five categories (1-5): } 1=\text { healthy, } \\
2=\text { mild systemic disease, } 3=\text { severe systemic disease, } 4=\text { severe disease that is a constant } \\
\text { threat to life, } 5 \text { = moribund. }\end{array}$ \\
\hline
\end{tabular}

Risk of bias

\begin{tabular}{|c|c|c|}
\hline Bias & Authors' judgement & Support for judgement \\
\hline $\begin{array}{l}\text { Random sequence generation (selection } \\
\text { bias) }\end{array}$ & Unclear risk & $\begin{array}{l}\text { "prospective study"; "who were randomly } \\
\text { distributed in two groups (group MNS= } \\
40 \text { patients and group TA = } 30 \text { patients) } \\
\text { according to the technique." Unexplained } \\
\text { imbalance. }\end{array}$ \\
\hline Allocation concealment (selection bias) & Unclear risk & No details of method. \\
\hline $\begin{array}{l}\text { Blinding (performance bias and detection } \\
\text { bias) } \\
\text { All outcomes }\end{array}$ & High risk & No mention. \\
\hline $\begin{array}{l}\text { Incomplete outcome data (attrition bias) } \\
\text { All outcomes }\end{array}$ & Unclear risk & $\begin{array}{l}\text { Likely that all participants accounted for, } \\
\text { but not stated explicitly. }\end{array}$ \\
\hline
\end{tabular}


Imbelloni 2005 (Continued)

\begin{tabular}{|c|c|c|}
\hline Selective reporting (reporting bias) & Unclear risk & $\begin{array}{l}\text { No prior protocol and vague in the defini- } \\
\text { tion of outcomes. }\end{array}$ \\
\hline Balance in baseline characteristics? & Unclear risk & $\begin{array}{l}\text { Balanced for sex, age, weight and height } \\
\text { but no information on surgery. }\end{array}$ \\
\hline Free from performance bias? & Unclear risk & Insufficient information to judge this. \\
\hline
\end{tabular}

\section{Inberg 1999}

\begin{tabular}{ll} 
Methods & $\begin{array}{l}\text { Method of randomization: computer based, organised by the statistical department. } \\
\text { Patient blinded. } \\
\text { Blinded outcome assessor. } \\
\text { No loss to follow-up. }\end{array}$ \\
\hline Participants & $\begin{array}{l}\text { Tampere, Finland } \\
\text { Period of study: } 1996 \text { to } 1997 . \\
50 \text { adults scheduled for upper limb surgery under axillary block anaesthesia. Informed } \\
\text { consent. } \\
\text { Male: } 74 \% \text {; mean age: } 44.5 \text { years. } \\
\text { Excluded: weight < } 50 \mathrm{~kg} \text { or }>100 \mathrm{~kg} \text {; surgery proximal from the elbow joint. }\end{array}$
\end{tabular}

Interventions

Double versus single injection (both groups using neurostimulation method).

All received local anaesthetic (LA) solution: Prilocaine $1 \%$ and bupivacaine $0.5 \%$ in 1:1 ratio; total volume $0.7 \mathrm{ml} / \mathrm{kg}$ body weight. Nerve blockade facilitated using $22 \mathrm{G}$ insulated needle and nerve stimulator. All blocks carried out by one operator.

Initial sedation with diazepam. Initial subcutaneous injection of 2 to $3 \mathrm{ml} \mathrm{LA}$.

1. Double injection: injection (half volume) LA to median nerve followed by injection (rest of volume) LA to radial nerve (14 cases) or ulnar (11 cases).

2. Single injection: single injection of LA to median nerve ( 23 cases); radial nerve (1 case) or ulnar nerve (1 case).

Subcutaneous injection of $5 \mathrm{ml}$ LA to block medial cutaneous nerves of the arm.

$\begin{array}{ll}\text { Outcomes } & \text { Length of follow-up: } 40 \text { minutes (and duration of surgery). } \\ \text { Sensory blockade } & \text { Motor blockade } \\ \text { Analgesic failure (use of supplementary anaesthesia; new plexus block, general anaesthe- } & \text { sia; use of opioids for tourniquet pain or pain in operation area) } \\ \text { Duration of surgery } \\ \text { Duration of tourniquet use } \\ \text { Tourniquet discomfort and pain } \\ \text { Problems (during operation) }\end{array}$

Notes

Reply to request for details of methods, type of surgery and details of participants receiving general and another full plexus block received from Dr Annila on 21/12/04. Original patient papers are now missing. 
Inberg 1999 (Continued)

\section{Risk of bias}

\begin{tabular}{|c|c|c|}
\hline Bias & Authors' judgement & Support for judgement \\
\hline $\begin{array}{l}\text { Random sequence generation (selection } \\
\text { bias) }\end{array}$ & Low risk & $\begin{array}{l}\text { "computer-based randomization", organ- } \\
\text { ised by the statistical department. }\end{array}$ \\
\hline Allocation concealment (selection bias) & Unclear risk & No information on concealment. \\
\hline $\begin{array}{l}\text { Blinding (performance bias and detection } \\
\text { bias) } \\
\text { All outcomes }\end{array}$ & Low risk & $\begin{array}{l}\text { "The evaluation of the sensory and motor } \\
\text { blocks was blinded, and the patient was un- } \\
\text { aware of the method used, which makes the } \\
\text { study double blind." }\end{array}$ \\
\hline
\end{tabular}

Incomplete outcome data (attrition bias) Low risk

All outcomes

No loss to follow-up. Information supplied by trial author on the particular circumstances of two patients, who received respectively a new plexus block and general anaesthesia.

\begin{tabular}{|c|c|c|}
\hline Selective reporting (reporting bias) & Unclear risk & Possible but no protocol available. \\
\hline Balance in baseline characteristics? & Unclear risk & $\begin{array}{l}\text { No information on type of surgery or men- } \\
\text { tal status. No statistically significant differ- } \\
\text { ences between the two groups in age, gen- } \\
\text { der, weight or height. }\end{array}$ \\
\hline
\end{tabular}

\begin{tabular}{l|l} 
Free from performance bias? $\quad$ Low risk
\end{tabular}

Seemingly so: same experienced operator and anaesthetic procedures. "All blocks were performed by the first author, who is experienced in axillary block."

\section{K-Nielsen 1997}

Methods

Participants
Method of randomization: computer-generated random allocation assuring an equal number of patients in both groups was obtained beforehand and sealed in numbered envelopes. An envelope containing the random assignment was opened after the patient's arrival at the anaesthesia room.

Blinded outcome assessor.

No loss to follow-up.

\section{Copenhagen, Denmark}

Period of study: 1995 to 1996.

80 people undergoing elective hand surgery: arthrodeses, arthroplasties, osteosyntheses (K-wire, Herbert screw etc), nerve sutures, finger amputations, neuroma or ganglion removals, hardware removals, wrist arthroscopies. Informed consent.

Male: 66\%; mean age: 46 years, range: 18 to 75 years.

Excluded: ASA physical status $>3$ (see notes). Allergy to amide type LA, pregnancy, 
K-Nielsen 1997 (Continued)

inability to communicate, neurological disorders affecting peripheral nerves and resulting sensory loss and/or motor weakness (e.g. advanced neuropathies - uraemic or diabetic)

$\begin{array}{ll}\text { Interventions } & \text { Multiple versus single injection (both groups using neurostimulation method). } \\ \text { All received local anaesthetic (LA) solution: } 1 \% \text { mepivacaine with adrenaline } 5 \mu \mathrm{g} / \mathrm{ml} . \\ \text { Nerve blockade facilitated using } 22 \mathrm{G} \text { insulated short-bevelled needle and nerve stimu- } \\ \text { lator. All blocks carried out by one operator. } \\ \text { Initial sedation with diazepam. Initial subcutaneous injection of } 5 \mathrm{ml} \mathrm{LA} \text { to anaesthetise } \\ \text { medial cutaneous nerves of arm or forearm. } \\ \begin{array}{l}\text { 1. Multiple injection: injection of } 10 \mathrm{ml} \mathrm{LA} \text { cephalad to artery, then injection below } \\ \text { artery - } 20 \mathrm{ml} \text { at point of maximum stimulation OR if } 2 \text { nerves located: } 15 \mathrm{ml} \text { close to } \\ \text { each nerve. If just one located then final } 10 \mathrm{ml} \text { into coracobrachial muscle. } \\ \text { 2. Single injection: injection of } 40 \mathrm{ml} \mathrm{LA} \text { to one nerve: median nerve (32), ulnar (6), } \\ \text { radial (2); then } 20 \mathrm{ml} \text { to radial nerve. }\end{array}\end{array}$

Outcomes

Length of follow-up: surgical follow-up (not stated) for adverse neurological outcomes; onset of sensory block assessed every 10 minutes (and duration of surgery).

Sensory blockade

Motor blockade

Analgesic failure (use of supplementary anaesthesia; general anaesthesia; use of opioids for tourniquet pain in operation area)

Time to be ready for surgery

Duration of tourniquet use

Tourniquet discomfort and pain

Problems (during injection and operation)

Long-term complications (none)

Notes

Reply to request for details of types of surgery, exclusion criteria and so on received from Dr Koscielniak-Nielsen on 11/11/2004.

The ASA (American Society of Anesthesiologists) physical status classification is a system for assessing the fitness of patients before surgery. It has five categories (1-5): $1=$ healthy, $2=$ mild systemic disease, 3 = severe systemic disease, $4=$ severe disease that is a constant threat to life, $5=$ moribund.

\section{Risk of bias}

\begin{tabular}{|c|c|c|}
\hline Bias & Authors' judgement & Support for judgement \\
\hline $\begin{array}{l}\text { Random sequence generation (selection } \\
\text { bias) }\end{array}$ & Low risk & $\begin{array}{l}\text { "A computer-generated random allocation } \\
\text { assuring an equal number of patients in } \\
\text { both groups was obtained beforehand ...." }\end{array}$ \\
\hline Allocation concealment (selection bias) & Low risk & $\begin{array}{l}\text { "A computer-generated random allocation } \\
\text { assuring an equal number of patients in } \\
\text { both groups was obtained beforehand and } \\
\text { sealed in numbered envelopes. An enve- } \\
\text { lope containing the random assignment } \\
\text { was opened after the patient's arrival at the } \\
\text { anaesthesia room." }\end{array}$ \\
\hline
\end{tabular}


K-Nielsen 1997 (Continued)

\begin{tabular}{|c|c|c|}
\hline $\begin{array}{l}\text { Blinding (performance bias and detection } \\
\text { bias) } \\
\text { All outcomes }\end{array}$ & Low risk & $\begin{array}{l}\text { "All the blocks were performed by the first } \\
\text { author [who left the room] and assessed by } \\
\text { the others... The [randomization] envelope } \\
\text { was then resealed and attached to the as- } \\
\text { sessment form." }\end{array}$ \\
\hline $\begin{array}{l}\text { Incomplete outcome data (attrition bias) } \\
\text { All outcomes }\end{array}$ & Low risk & No loss to follow-up. \\
\hline Selective reporting (reporting bias) & Low risk & $\begin{array}{l}\text { No protocol but same plan for series of } \\
\text { trials. Clearly reported primary outcomes. } \\
\text { Ethics committee acceptance reported. }\end{array}$ \\
\hline Balance in baseline characteristics? & Unclear risk & $\begin{array}{l}\text { Yes, aside from the distribution of the var- } \\
\text { ious elective hand operations. }\end{array}$ \\
\hline Free from performance bias? & Low risk & $\begin{array}{l}\text { All the blocks were performed by the first } \\
\text { author [an experienced anaesthetist]. Other } \\
\text { care seemed comparable. }\end{array}$ \\
\hline
\end{tabular}

\section{K-Nielsen 1998}

Methods

Interventions
Method of randomization: computer-generated random allocation assuring an equal number of patients in both groups was obtained beforehand and sealed in numbered envelopes. An envelope containing the random assignment was opened after the patient's arrival at the anaesthesia room.

Blinded outcome assessor.

No loss to follow-up.

\begin{tabular}{ll}
\hline Participants & $\begin{array}{l}\text { Copenhagen, Denmark } \\
\text { Period of study: } 1996 \text { to } 1997 . \\
100 \text { people undergoing acute (nerve and/or tendon sutures, K-wire or Hoffmann os- } \\
\text { teosynthesis) or elective hand, wrist or forearm surgery. Informed consent. } \\
\text { Male: } 64 \% \text {; mean age: } 47 \text { years, range: } 18 \text { to } 80 \text { years. } \\
\text { Excluded: ASA physical status }>3 \text { (see notes). Allergy to amide type LA, pregnancy, in- } \\
\text { ability to co-operate, diseases affecting sensory or motor function of the upper extremity. }\end{array}$ \\
\hline Multiple (neurostimulation method) versus double injection (transarterial method). \\
All received local anaesthetic (LA) solution: $1 \%$ mepivacaine with adrenaline $5 \mu \mathrm{mg} / \mathrm{ml}$. \\
Nerve blockade facilitated using $22 \mathrm{G}$ or $24 \mathrm{G}$ insulated short-bevelled needle with nerve \\
$\begin{array}{l}\text { stimulator in place. All blocks carried out by one operator. } \\
\text { Initial sedation with diazepam. Initial subcutaneous injection of } 5 \mathrm{ml} \text { LA to anaesthetise } \\
\text { medial cutaneous nerves of arm or forearm. } \\
\text { 1. Multiple injection: injection of } 10 \mathrm{ml} \text { LA to } 4 \text { terminal motor nerves (musculocuta- } \\
\text { neous, median, radial and ulnar). Connected to nerve stimulator, current }=1.5 \mathrm{~mA} . \\
\text { 2. Double injection "transarterial“: injection of } 20 \text { ml LA deep to and } 20 \mathrm{ml} \text { superficial } \\
\text { to axillary artery. Connected to nerve stimulator but current }=0 \mathrm{~mA} .\end{array}$ \\
\hline
\end{tabular}




\section{K-Nielsen 1998 (Continued)}

\begin{tabular}{|c|c|}
\hline Outcomes & $\begin{array}{l}\text { Length of follow-up: surgical follow-up (not stated) for adverse neurological outcomes; } \\
\text { onset of sensory block assessed every } 10 \text { minutes (and duration of surgery). } \\
\text { Sensory blockade } \\
\text { Motor blockade } \\
\text { Analgesic failure (use of supplementary anaesthesia; use of opioids for tourniquet pain } \\
\text { in operation area) } \\
\text { Time to be ready for surgery } \\
\text { Duration of tourniquet use } \\
\text { Tourniquet discomfort and pain } \\
\text { Problems (during injection and operation) } \\
\text { Long-term complications (none) }\end{array}$ \\
\hline Notes & $\begin{array}{l}\text { Reply to request for details of types of surgery received from Dr Koscielniak-Nielsen on } \\
\text { 15/11/2004. } \\
\text { The ASA (American Society of Anesthesiologists) physical status classification is a system } \\
\text { for assessing the fitness of patients before surgery. It has five categories (1-5): } 1 \text { = healthy, } \\
2 \text { = mild systemic disease, } 3 \text { = severe systemic disease, } 4 \text { = severe disease that is a constant } \\
\text { threat to life, } 5 \text { = moribund. }\end{array}$ \\
\hline
\end{tabular}

\section{Risk of bias}

\begin{tabular}{|c|c|c|}
\hline Bias & Authors' judgement & Support for judgement \\
\hline $\begin{array}{l}\text { Random sequence generation (selection } \\
\text { bias) }\end{array}$ & Low risk & $\begin{array}{l}\text { "A computer-generated random allocation } \\
\text { assuring an equal number of patients in } \\
\text { both groups was obtained beforehand ...." }\end{array}$ \\
\hline Allocation concealment (selection bias) & Low risk & $\begin{array}{l}\text { "A computer-generated random allocation } \\
\text { assuring an equal number of patients in } \\
\text { both groups was obtained beforehand and } \\
\text { sealed in numbered envelopes. An enve- } \\
\text { lope containing the random assignment } \\
\text { was opened after the patient's arrival at the } \\
\text { anaesthesia room." }\end{array}$ \\
\hline $\begin{array}{l}\text { Blinding (performance bias and detection } \\
\text { bias) } \\
\text { All outcomes }\end{array}$ & Low risk & $\begin{array}{l}\text { "All the blocks were performed by the first } \\
\text { author [who left the room] and assessed by } \\
\text { the others, who were unaware of the applied } \\
\text { nerve block." }\end{array}$ \\
\hline $\begin{array}{l}\text { Incomplete outcome data (attrition bias) } \\
\text { All outcomes }\end{array}$ & Low risk & No loss to follow-up. \\
\hline Selective reporting (reporting bias) & Low risk & $\begin{array}{l}\text { No protocol but same plan for series of } \\
\text { trials. Clearly reported primary outcomes. } \\
\text { Ethics committee acceptance reported. }\end{array}$ \\
\hline
\end{tabular}


K-Nielsen 1998 (Continued)

\begin{tabular}{l|l|l}
\hline Balance in baseline characteristics? & Unclear risk & $\begin{array}{l}\text { Yes, aside from the distribution of the vari- } \\
\text { ous operations, which were elective or acute } \\
\text { hand, wrist or forearm surgery. }\end{array}$ \\
\hline Free from performance bias? & Low risk & $\begin{array}{l}\text { All the blocks were performed by the first } \\
\text { author [an experienced anaesthetist]. Other } \\
\text { care seemed comparable. }\end{array}$ \\
\hline
\end{tabular}

\section{K-Nielsen 1999a}

Methods

Method of randomization: computer-generated random allocation assuring an equal number of patients in both groups was obtained beforehand and sealed in numbered envelopes. An envelope containing the random assignment was opened after the patient's arrival at the anaesthesia room.

Blinded outcome assessor(s).

No loss to follow-up but 1 excluded due to serious adverse effect.

\begin{tabular}{|c|c|}
\hline Participants & $\begin{array}{l}\text { Copenhagen, Denmark } \\
\text { Period of study: } 1998 . \\
101 \text { people undergoing acute (nerve and/or tendon sutures, fracture osteosyntheses, am- } \\
\text { putations, wound revisions etc) or elective (Dupuytrens, arthroplasties, arthrodeses, lig- } \\
\text { ament reconstructions, Hunter I or II, caput ulnae resections, scaphoideum osteosyn- } \\
\text { theses, neuroma or ganglion removals, carpal tunnel surgery etc) hand, wrist or forearm } \\
\text { surgery. Informed consent. } \\
\text { Male: } 64 \% \text {; mean age: } 49.5 \text { years, range: } 18 \text { to } 80 \text { years. } \\
\text { Excluded: ASA physical status > } 2 \text { (see notes). Allergy to amide type LA, pregnancy, in- } \\
\text { ability to co-operate, diseases affecting sensory or motor function of the upper extremity. }\end{array}$ \\
\hline Interventions & $\begin{array}{l}\text { Multiple (neurostimulation method) versus double injection (transarterial method). } \\
\text { All received local anaesthetic (LA) solution: } 2 \% \text { mepivacaine with adrenaline } 5 \mu \mathrm{g} / \mathrm{ml} \text {. } \\
\text { Nerve blockade facilitated using } 22 \mathrm{G} \text { or } 24 \mathrm{G} \text { insulated short-bevelled needle with nerve } \\
\text { stimulator in place. Blocks carried out by one operator or under his supervision. } \\
\text { Initial sedation with diazepam. Initial subcutaneous injection of } 5 \mathrm{ml} \mathrm{LA} \mathrm{(} 1 \% \text { mepiva- } \\
\text { caine) to anaesthetise medial cutaneous nerves of arm or forearm. } \\
\text { 1. Multiple injection: injection of } 10 \mathrm{ml} \mathrm{LA} \text { to } 4 \text { terminal motor nerves (Musculocuta- } \\
\text { neous, median, radial and ulnar). Connected to nerve stimulator, current = } 1.5 \mathrm{~mA} \text {. } \\
\text { 2. Double injection "transarterial“: injection of } 20 \mathrm{ml} \text { LA deep to and } 20 \mathrm{ml} \text { superficial } \\
\text { to axillary artery. Connected to nerve stimulator but current }=0 \mathrm{~mA} \text {. }\end{array}$ \\
\hline
\end{tabular}

Outcomes

Length of follow-up: surgical follow up ( 5 to 10 days, then 3 to 4 weeks after) for adverse neurological outcomes; onset of sensory block assessed every 10 minutes.

Sensory blockade

Motor blockade

Analgesic failure (use of supplementary anaesthesia; use of opioids for tourniquet pain in operation area)

Time to be ready for surgery

Pain during block

Duration of tourniquet use 
K-Nielsen 1999a (Continued)

Tourniquet discomfort and pain

Problems (during injection and operation)

Long-term complications (none)

Notes
Exoup who developed hypertension, atrial fibrillation, became agitated and lost con-
sciousness 12 minutes after block performance. After intravenous administration of la-
betol, metoprolol and midazolam his condition improved and he woke up 15 minutes
later.
Details of types of surgery, study period received from Dr Koscielniak-Nielsen on $02 /$
$12 / 2004$.
The ASA (American Society of Anesthesiologists) physical status classification is a system
for assessing the fitness of patients before surgery. It has five categories $(1-5): 1=$ healthy,
$2=$ mild systemic disease, $3=$ severe systemic disease, $4=$ severe disease that is a constant
threat to life, $5=$ moribund.

Risk of bias

\begin{tabular}{|c|c|c|}
\hline Bias & Authors' judgement & Support for judgement \\
\hline $\begin{array}{l}\text { Random sequence generation (selection } \\
\text { bias) }\end{array}$ & Low risk & $\begin{array}{l}\text { "A computer-generated random allocation } \\
\text { assuring an equal number of patients in } \\
\text { both groups was obtained beforehand ...." }\end{array}$ \\
\hline Allocation concealment (selection bias) & Low risk & $\begin{array}{l}\text { "A computer-generated random allocation } \\
\text { assuring an equal number of patients in } \\
\text { both groups was obtained beforehand and } \\
\text { sealed in numbered envelopes. An enve- } \\
\text { lope containing the random assignment } \\
\text { was opened after the patient's arrival at the } \\
\text { anaesthesia room." }\end{array}$ \\
\hline
\end{tabular}

Blinding (performance bias and detection Low risk bias)

All outcomes

Incomplete outcome data (attrition bias) Low risk All outcomes

Selective reporting (reporting bias) Low risk

Balance in baseline characteristics?
Unclear risk
"All blocks were assessed by the anaesthetists, who were unaware of the applied nerve block technique."

No loss to follow-up but 1 excluded due to serious adverse effect.

No protocol but same plan for series of trials. Clearly reported primary outcomes. Ethics committee acceptance reported.

Yes, aside from the distribution of the various operations, which were elective or acute hand, wrist or forearm surgery. 
K-Nielsen 1999a (Continued)

\begin{tabular}{l|l}
\hline Free from performance bias? & $\begin{array}{l}\text { While } 38 \% \text { versus } 32 \% \text { of blocks were } \\
\text { done by residents and other staff members } \\
\text { (rather than the first author [an experienced } \\
\text { anaesthetist], the first author supervised all } \\
\text { blocks. Other care seemed comparable. }\end{array}$ \\
\hline
\end{tabular}

\section{K-Nielsen 1999b}

\begin{tabular}{ll} 
Methods & $\begin{array}{l}\text { Method of randomization: computer-generated random allocation assuring an equal } \\
\text { number of patients in both groups was obtained beforehand and sealed in numbered } \\
\text { envelopes. An envelope containing the random assignment was opened after the patient's } \\
\text { arrival at the anaesthesia room. } \\
\text { Blinded outcome assessor. } \\
\text { No loss to follow-up. }\end{array}$ \\
\hline Participants & $\begin{array}{l}\text { Copenhagen, Denmark } \\
\text { Period of study: } 1998 .\end{array}$ \\
\hline $\begin{array}{l}106 \text { people undergoing acute (nerve and/or tendon sutures, fracture osteosyntheses, am- } \\
\text { putations, wound revisions etc) or elective (Dupuytrens, arthroplasties, arthrodeses, lig- } \\
\text { ament reconstructions, Hunter I or II, caput ulnae resections, scaphoideum osteosyn- } \\
\text { theses, neuroma or ganglion removals, carpal tunnel surgery etc) hand, wrist or forearm } \\
\text { surgery. Informed consent. } \\
\text { Male: } 57 \% \text {; mean age: } 45.5 \text { years, range: } 18 \text { to } 80 \text { years. } \\
\text { Excluded: ASA physical status }>2 \text { (see notes). Allergy to amide type local anaesthetic } \\
\text { (LA), pregnancy, inability to co-operate, diseases affecting sensory or motor function of } \\
\text { the upper extremity. }\end{array}$
\end{tabular}

Interventions

Multiple (neurostimulation method) versus single injection (transarterial/paraesthesia method).

Blocks carried out by first author - consultant anaesthetist - other staff members or supervised residents.

Initial sedation with diazepam to apprehensive patients. Initial subcutaneous injection of $5 \mathrm{ml}$ mepivacaine $1 \%$ with adrenaline $5 \mu \mathrm{g} / \mathrm{ml}$ to anaesthetise medial cutaneous nerves of arm or forearm.

1. Multiple injection: injection using 24 gauge, $25 \mathrm{~mm}$ long insulated short-bevelled cannula of $5 \mathrm{ml}$ mepivacaine $1 \%$ with adrenaline $5 \mu \mathrm{g} / \mathrm{ml}$ to 4 terminal motor nerves (Musculocutaneous, median, radial and ulnar). Connected to nerve stimulator, current $=1.5 \mathrm{~mA}$.

2. Single injection: injection with 25 gauge, $35 \mathrm{~mm}$ long hypodermic needle of 80 $\mathrm{ml}$ mepivacaine $1 \%$ with adrenaline $2.5 \mu \mathrm{g} / \mathrm{ml}$ LA behind transfixed axillary artery (beforehand if hand paraesthesia elicited). Connected to nerve stimulator but current = $0 \mathrm{~mA}$.

Outcomes

Length of follow-up: surgical follow up ( 5 to 10 days, then 3 to 4 weeks after) for adverse neurological outcomes; onset of sensory block assessed every 10 minutes.

Sensory blockade

Motor blockade

Analgesic failure (use of supplementary anaesthesia; use of opioids for tourniquet pain 
K-Nielsen 1999b (Continued)

\begin{tabular}{|c|c|}
\hline & $\begin{array}{l}\text { in operation area; use of propofol for restlessness caused by tourniquet) } \\
\text { Time to be ready for surgery } \\
\text { Pain during block } \\
\text { Duration of tourniquet use } \\
\text { Tourniquet discomfort and pain } \\
\text { Problems (during injection and operation) } \\
\text { Long-term complications (none) }\end{array}$ \\
\hline Notes & $\begin{array}{l}\text { One of the two excluded trial participants was an Inuit who didn't understand trial } \\
\text { procedures. The other participant, who already had coronary artery disease, developed } \\
\text { chest pain - the surgery was cancelled. } \\
\text { Details of types of surgery, study period and other clarification received from Dr Ko- } \\
\text { scielniak-Nielsen on } 14 / 12 / 2004 \text {. } \\
\text { The ASA (American Society of Anesthesiologists) physical status classification is a system } \\
\text { for assessing the fitness of patients before surgery. It has five categories (1-5): } 1 \text { = healthy, } \\
2 \text { = mild systemic disease, } 3 \text { = severe systemic disease, } 4 \text { = severe disease that is a constant } \\
\text { threat to life, } 5 \text { = moribund. }\end{array}$ \\
\hline
\end{tabular}

\section{Risk of bias}

\begin{tabular}{|c|c|c|}
\hline Bias & Authors' judgement & Support for judgement \\
\hline $\begin{array}{l}\text { Random sequence generation (selection } \\
\text { bias) }\end{array}$ & Low risk & $\begin{array}{l}\text { "A computer-generated random allocation } \\
\text { assuring an equal number of patients in } \\
\text { both groups was obtained beforehand ...." }\end{array}$ \\
\hline Allocation concealment (selection bias) & Low risk & $\begin{array}{l}\text { "A computer-generated random allocation } \\
\text { assuring an equal number of patients in } \\
\text { both groups was obtained beforehand and } \\
\text { sealed in numbered envelopes. An enve- } \\
\text { lope containing the random assignment } \\
\text { was opened after the patient's arrival at the } \\
\text { anaesthesia room." }\end{array}$ \\
\hline
\end{tabular}

Blinding (performance bias and detection Low risk bias)

All outcomes

Incomplete outcome data (attrition bias) Low risk All outcomes

Selective reporting (reporting bias)
"The anesthetist performing the block ... restarted the stopwatch and left the room. The blocks were ....assessed by an anesthesiologist unaware of the applied technique."

No loss to follow-up although 2 were excluded; because of language and heart problems respectively.

No protocol but same plan for series of trials. Clearly reported primary outcomes. Ethics committee acceptance reported. 
K-Nielsen 1999b (Continued)

\begin{tabular}{l|l|l}
\hline Balance in baseline characteristics? & Unclear risk & $\begin{array}{l}\text { Yes, aside from the distribution of the vari- } \\
\text { ous operations, which were elective or acute } \\
\text { hand, wrist or forearm surgery. }\end{array}$ \\
\hline Free from performance bias? & Low risk & $\begin{array}{l}\text { Blocks carried out by first author - con- } \\
\text { sultant anaesthetist - other staff members } \\
\text { or supervised residents. Other care seemed } \\
\text { comparable. }\end{array}$ \\
\hline
\end{tabular}

Lavoie 1992

Methods

in 15 groups of 5 patients each (group 1, group 2 etc allocated in a random way into
each one of the 15 groups).”
$\begin{aligned} & \text { Double-blind: anaesthetist carrying out assessments and patients were blind to injection } \\ & \text { technique. } \\ & \text { No loss to follow-up. }\end{aligned}$

Participants

Interventions

Sherbrooke, Quebec, Canada

Period of study: 1991.

75 people undergoing upper limb surgery including the elbow down to the hand: fractures, soft tissues. Informed consent.

Male: 55\%; mean age: 41 years.

Excluded: no details.

Multiple versus double versus single (radial nerve) versus single (median nerve) versus single (ulnar nerve) injection.

All received local anaesthetic (LA) solution: $30 \mathrm{ml} /$ square metre body surface (approximately $50 \mathrm{ml} / 70 \mathrm{~kg}$ body weight) lidocaine $1 \%$ with adrenaline $5 \mu \mathrm{g} / \mathrm{ml}$. A tourniquet was used in all cases.

No premedication, sedation or IV analgesia mentioned. Anaesthetist performing the blocks was aware of the surgical site. After locating, by palpation, the axillary nerve in the axilla, $2 \mathrm{ml}$ of $2 \%$ lidocaine injected subcutaneously to block medial cutaneous nerves of the arm. A 22-gauge insulated needle connected to peripheral nerve stimulator used to locate the nerves ( $0.5 \mathrm{~mA}$ current).

1. Multiple injection: to musculocutaneous, radial, median and ulnar nerves. LA volume equally divided between the 4 injections.

2. Double injection: to musculocutaneous and one of radial, median or ulnar nerves directly related to surgical site. LA volume equally divided between the 2 injections.

3. Single injection: to radial nerve of full volume of LA.

4. Single injection: to median nerve of full volume of LA.

5. Single injection: to ulnar nerve of full volume of LA. 
Lavoie 1992 (Continued)

\begin{tabular}{|c|c|c|}
\hline Notes & \multicolumn{2}{|c|}{$\begin{array}{l}\text { Reply to request for details of methods, types of surgery and results, including adverse } \\
\text { effects, received from Dr Martin on 05/01/05. }\end{array}$} \\
\hline Risk of bias & & \\
\hline Bias & Authors' judgement & Support for judgement \\
\hline $\begin{array}{l}\text { Random sequence generation (selection } \\
\text { bias) }\end{array}$ & Low risk & $\begin{array}{l}\text { "We used a random number table. The } 75 \\
\text { patients were blocked in } 15 \text { groups of } 5 \text { pa- } \\
\text { tients each (group } 1 \text {, group } 2 \text { etc allocated } \\
\text { in a random way into each one of the } 15 \\
\text { groups)." }\end{array}$ \\
\hline
\end{tabular}

$\begin{array}{lll}\text { Allocation concealment (selection bias) } & \text { Unclear risk } & \begin{array}{l}\text { No information, but some predictability } \\ \text { may have occurred at the end of each block. }\end{array}\end{array}$

\begin{tabular}{|c|c|c|}
\hline $\begin{array}{l}\text { Blinding (performance bias and detection } \\
\text { bias) } \\
\text { All outcomes }\end{array}$ & Low risk & $\begin{array}{l}\text { "The anaesthetist performing the block was } \\
\text { aware of the surgery but another anaes- } \\
\text { thetist unaware of the patients' group eval- } \\
\text { uated the sensory and motor blocks .." ".. } \\
\text { the patient did not know what aspect of his } \\
\text { axillary block was studied specifically .." }\end{array}$ \\
\hline $\begin{array}{l}\text { Incomplete outcome data (attrition bias) } \\
\text { All outcomes }\end{array}$ & Low risk & No loss to follow-up. \\
\hline Selective reporting (reporting bias) & Unclear risk & Possible but no protocol available. \\
\hline Balance in baseline characteristics? & Low risk & $\begin{array}{l}\text { Fine. Although no details of surgery, there } \\
\text { was balance in the implicated nerves. }\end{array}$ \\
\hline Free from performance bias? & Low risk & $\begin{array}{l}\text { Seems likely and the author suggested that } \\
\text { the "technique of randomisation by blocks } \\
\text { allows that the learning of the technique is } \\
\text { uniform on the } 5 \text { groups of patients". }\end{array}$ \\
\hline
\end{tabular}

Pere 1993

\begin{tabular}{ll}
\hline Methods & $\begin{array}{l}\text { Method of randomization: not stated. } \\
\text { No blinding indicated. } \\
\text { No loss to follow-up (assumed for } 3 \text { hours follow-up). }\end{array}$ \\
\hline Participants & $\begin{array}{l}\text { Helsinki, Finland } \\
\text { Period of study: not stated. } \\
50 \text { people undergoing hand, forearm or elbow surgery. Informed consent. } \\
\text { Male: not stated; mean age: } 37 \text { years. } \\
\text { Excluded: ASA physical status }>2 \text { (see notes). }\end{array}$ \\
\hline
\end{tabular}




\begin{tabular}{|c|c|}
\hline Interventions & $\begin{array}{l}\text { Double (transarterial method) versus single injection (neurostimulation method). } \\
\text { All received LA solution: mepivacaine } 1 \% \text { with adrenaline } 5 \mu \mathrm{g} / \mathrm{ml} \text {. } \\
\text { Premedication with diazepam and oxycodone. } \\
\text { 1. Double injection "transarterial": injection using } 0.7 \times 50 \mathrm{~mm} \text { needle advanced through } \\
\text { the artery. Injection of half of } 45 \mathrm{ml} \text { LA deep to and half superficial to axillary artery. } \\
\text { 2. Single "perivascular" injection: injection using } 0.7 \times 50 \mathrm{~mm} \text { needle and facilitated by } \\
\text { nerve stimulator of } 45 \mathrm{ml} \text { LA after location of axillary brachial plexus. } \\
\text { Neurovasular sheath compressed during the injection and for } 3 \text { minutes afterwards. }\end{array}$ \\
\hline Outcomes & $\begin{array}{l}\text { Length of follow-up: } 3 \text { hours. } \\
\text { Sensory blockade - } 8 \text { nerves } \\
\text { Motor blockade } \\
\text { Analgesic failure (use of supplementary blocks; general anaesthesia; use of opioids) } \\
\text { Duration of tourniquet use }\end{array}$ \\
\hline Notes & $\begin{array}{l}\text { Subsidiary radiological study of } 16 \text { people also performed. It was not clear if the people } \\
\text { were randomized to the same comparison as the clinical trial. Need for supplementary } \\
\text { blocks }(2 / 8 \text { versus } 2 / 8) \text { and more than } 1 \text { dose of opoid ( } 1 \text { versus } 1) \text { was the same in both } \\
\text { groups. } \\
\text { Response from Dr Pere, received } 10 / 02 / 05 \text {, indicated, with regret, that there was now } \\
\text { no more information available on this trial. } \\
\text { The ASA (American Society of Anesthesiologists) physical status classification is a system } \\
\text { for assessing the fitness of patients before surgery. It has five categories }(1-5): 1 \text { = healthy, } \\
2=\text { mild systemic disease, } 3 \text { = severe systemic disease, } 4 \text { = severe disease that is a constant } \\
\text { threat to life, } 5=\text { moribund. }\end{array}$ \\
\hline
\end{tabular}

Risk of bias

\begin{tabular}{|c|c|c|}
\hline Bias & Authors' judgement & Support for judgement \\
\hline $\begin{array}{l}\text { Random sequence generation (selection } \\
\text { bias) }\end{array}$ & Unclear risk & $\begin{array}{l}\text { "Patients were allocated randomly to two } \\
\text { groups." }\end{array}$ \\
\hline Allocation concealment (selection bias) & Unclear risk & No details of method. \\
\hline $\begin{array}{l}\text { Blinding (performance bias and detection } \\
\text { bias) } \\
\text { All outcomes }\end{array}$ & High risk & No mention of blinding. \\
\hline $\begin{array}{l}\text { Incomplete outcome data (attrition bias) } \\
\text { All outcomes }\end{array}$ & Low risk & Seemed fine. \\
\hline Selective reporting (reporting bias) & Unclear risk & $\begin{array}{l}\text { Protocol not available. No mention of com- } \\
\text { plications. }\end{array}$ \\
\hline Balance in baseline characteristics? & Unclear risk & $\begin{array}{l}\text { "There were no differences between the } \\
\text { groups in patient age, height or weight.." } \\
\text { However, no details of type of surgery or }\end{array}$ \\
\hline
\end{tabular}


Pere 1993 (Continued)

gender.

Free from performance bias?

Unclear risk

No details of who administered the anaesthesia.

\section{Rodriguez 2005}

Methods

Method of randomization: computer-generated randomization list.

Blinded outcome assessor.

No loss to follow-up. Four incomplete procedures included in intention-to-treat analysis.

\begin{tabular}{ll}
\hline Participants & Santiago, Spain \\
& Period of study: not stated. \\
& 120 people undergoing surgery of the upper limb (not otherwise specified). Informed \\
consent. & Male: $27 \%$; mean age: 51 years. \\
Excluded: ASA physical status $>3$ (see notes). \\
\hline
\end{tabular}

Interventions

Multiple versus double versus single (median nerve) versus single (radial nerve) injection. All received local anaesthetic (LA) solution: 1.5\% mepivacaine; total volume $40 \mathrm{ml}$. All blocks were neurostimulation-guided with a $22 \mathrm{G}$ insulated block needle. All blocks were performed by one of two senior anaesthesiologists.

Sedative premedication with 1 to $3 \mathrm{mg}$ of IV midazolam according to clinical judgement.

1. Multiple injection: injection of $15 \mathrm{ml}$ to radial nerve, $15 \mathrm{ml}$ to median nerve, $10 \mathrm{ml}$ to musculocutaneous nerve.

2. Double injection: injection of $35 \mathrm{ml}$ on radial nerve, injection of $5 \mathrm{ml}$ on musculocutaneous nerve.

3. Single injection (median): injection of $40 \mathrm{ml}$ on median nerve.

4. Single injection (radial): injection of $40 \mathrm{ml}$ on radial nerve.

Blocks were supplemented preoperatively if the operative nerve distributions did not have complete sensory block before operation; timing of this was not specified.

Intraoperative pain was treated with infiltration of local anaesthetic at the site, or with injection of 50 to $100 \mathrm{mcg}$ of fentanyl. General anaesthesia was used if pain was persistent.

Outcomes

Length of follow-up: sensory and motor block assessed at 5 and 20 minutes. No followup detailed beyond that.

Sensory blockade

Motor blockade

Analgesic failure (use of supplementary anaesthesia; general anaesthesia; pain in operative field)

Block performance time

Notes

Request for additional information on method of randomization, blinding, and results sent to Dr Rodriguez on 13/07/2010; no reply received.

The ASA (American Society of Anesthesiologists) physical status classification is a system for assessing the fitness of patients before surgery. It has five categories (1-5): $1=$ healthy, $2=$ mild systemic disease, $3=$ severe systemic disease, $4=$ severe disease that is a constant threat to life, 5 = moribund. 
Rodriguez 2005 (Continued)

\section{Risk of bias}

\begin{tabular}{|c|c|c|}
\hline Bias & Authors' judgement & Support for judgement \\
\hline $\begin{array}{l}\text { Random sequence generation (selection } \\
\text { bias) }\end{array}$ & Low risk & $\begin{array}{l}\text { "Assignment was performed by means of a } \\
\text { computer-generated randomization list." }\end{array}$ \\
\hline Allocation concealment (selection bias) & Unclear risk & $\begin{array}{l}\text { No information on allocation conceal- } \\
\text { ment. }\end{array}$ \\
\hline $\begin{array}{l}\text { Blinding (performance bias and detection } \\
\text { bias) } \\
\text { All outcomes }\end{array}$ & Low risk & $\begin{array}{l}\text { Participants - not blinded. Caregivers - } \\
\text { not blinded. Outcome assessors - blinded. } \\
\text { No mention of safeguards, but plausible. } \\
\text { Blinding is within study limitations and } \\
\text { unlikely to influence outcome. }\end{array}$ \\
\hline $\begin{array}{l}\text { Incomplete outcome data (attrition bias) } \\
\text { All outcomes }\end{array}$ & High risk & $\begin{array}{l}\text { Intention-to-treat analysis was done and } \\
\text { there were none lost to follow-up. But the } \\
\text { length of follow-up was only } 20 \text { minutes, } \\
\text { yet authors state "we had the clinical im- } \\
\text { pression that many incomplete blocks pro- } \\
\text { gressed until } 30 \text { minutes." It is unclear if } \\
\text { they supplemented the blocks after } 20 \text { min- } \\
\text { utes, or later, yet this is reported as an out- } \\
\text { come. }\end{array}$ \\
\hline Selective reporting (reporting bias) & Unclear risk & $\begin{array}{l}\text { Protocol not available. No reporting of } \\
\text { complications, which is unusual for this } \\
\text { type of study. }\end{array}$ \\
\hline Balance in baseline characteristics? & Unclear risk & No details of type of surgery performed. \\
\hline Free from performance bias? & Low risk & $\begin{array}{l}\text { Blocks were administered by one of two } \\
\text { senior anaesthesiologists. }\end{array}$ \\
\hline
\end{tabular}

\section{Rodriguez 2008}

\begin{tabular}{ll} 
Methods & $\begin{array}{l}\text { Method of randomization: computer-generated randomization list. } \\
\text { Blinded outcome assessor. } \\
\text { Loss for follow-up: one patient in the double group excluded after randomization and } \\
\text { block performance as assessment was not possible. }\end{array}$ \\
\hline Participants & $\begin{array}{l}\text { Santiago, Spain } \\
\text { Period of study: not stated. } \\
60 \text { people undergoing surgery of the hand (49), forearm (3), elbow (8). Informed con- } \\
\text { sent. } \\
\text { Male: 48.3\%; mean age: } 58 \text { years. } \\
\text { Excluded: ASA physical status }>3 \text { (see notes). }\end{array}$ \\
\hline
\end{tabular}


Rodriguez 2008 (Continued)

\begin{tabular}{ll}
\hline Interventions & $\begin{array}{l}\text { Multiple versus double injection (both groups using neurostimulation method). } \\
\text { All received local anaesthetic (LA) solution: } 2 \% \text { mepivacaine of volume } 30 \mathrm{ml}, \text { and } \\
1 \% \text { mepivacaine of volume } 5 \mathrm{ml} \text { (to musculocutaneous nerve); total volume } 35 \mathrm{ml} \text {. All } \\
\text { blocks were neurostimulation-guided with a } 22 \mathrm{G} \text { insulated block needle. Identity and } \\
\text { experience level of operators performing block were not specified. } \\
\text { Sedative premedication with } 1 \text { to } 3 \mathrm{mg} \text { of IV midazolam. } \\
\text { 1. Multiple injection: injection of } 15 \mathrm{ml} \text { to radial nerve, } 15 \mathrm{ml} \text { to median nerve, } 5 \mathrm{ml} \text { to } \\
\text { musculocutaneous nerve. } \\
\text { 2. Double injection: injection of } 30 \mathrm{ml} \text { on radial nerve, injection of } 5 \mathrm{ml} \text { on musculo- } \\
\text { cutaneous nerve. }\end{array}$ \\
\hline $\begin{array}{l}\text { Length of follow-up: sensory and motor block assessed at } 10,20 \text { and } 30 \text { minutes. } \\
\text { Sensory blockade }\end{array}$ \\
$\begin{array}{l}\text { Motor blockade } \\
\text { Analgesic failure (use of supplementary anaesthesia; general anaesthesia; pain in operative } \\
\text { field) } \\
\text { Block performance time (reported as median and ranges) } \\
\text { Acute complications during block procedure }\end{array}$ \\
$\begin{array}{l}\text { Request for additional information on method of randomization, blinding, and results } \\
\text { sent to Dr Rodriguez on } 13 / 07 / 2010 ; \text { no reply received. }\end{array}$ \\
$\begin{array}{l}\text { The ASA (American Society of Anesthesiologists) physical status classification is a system } \\
\text { for assessing the fitness of patients before surgery. It has five categories }(1-5): 1=\text { healthy, } \\
2=\text { mild systemic disease, } 3=\text { severe systemic disease, } 4=\text { severe disease that is a constant } \\
\text { threat to life, } 5=\text { moribund. }\end{array}$ \\
\hline Notes
\end{tabular}

Risk of bias

\begin{tabular}{l|l|l}
\hline Bias & Authors' judgement & Support for judgement \\
\hline $\begin{array}{l}\text { Random sequence generation (selection } \\
\text { bias) }\end{array}$ & Low risk & $\begin{array}{l}\text { "Assignment was performed by computer- } \\
\text { generated randomization list." }\end{array}$ \\
\hline $\begin{array}{l}\text { Allocation concealment (selection bias) } \\
\text { Blinding (performance bias and detection } \\
\text { bias) } \\
\text { All outcomes }\end{array}$ & Low risk & No information provided. \\
\hline $\begin{array}{l}\text { Incomplete outcome data (attrition bias) } \\
\text { All outcomes }\end{array}$ & Unclear risk & $\begin{array}{l}\text { Participants - not blinded. Caregivers - } \\
\text { not blinded. Outcome assessors - blinded. } \\
\text { No mention of safeguards, but plausible. }\end{array}$ \\
\hline
\end{tabular}


Rodriguez 2008 (Continued)

\begin{tabular}{|c|c|c|}
\hline Selective reporting (reporting bias) & Unclear risk & No protocol and side effects not reported \\
\hline Balance in baseline characteristics? & Unclear risk & $\begin{array}{l}\text { Baseline characteristics balanced but no de- } \\
\text { tails of distribution of types of surgery. }\end{array}$ \\
\hline Free from performance bias? & Unclear risk & $\begin{array}{l}\text { The identity and experience of care } \\
\text { providers was not stated. }\end{array}$ \\
\hline
\end{tabular}

\section{Serradell Catalan 2001}

\begin{tabular}{ll} 
Methods & $\begin{array}{l}\text { Method of randomization: use of a computer-generated table of random numbers to } \\
\text { generate a randomization list. } \\
\text { Blinded outcome assessor. } \\
\text { No loss to follow-up. }\end{array}$ \\
\hline Participants & $\begin{array}{l}\text { Barcelona, Spain } \\
\text { Period of study: } 1999 \text { to } 2000 . \\
100 \text { adults (> } 18 \text { years) undergoing upper limb (forearm, wrist or hand) post-traumatic } \\
\text { orthopaedic surgery. ASA physical status1-3 (see notes). Informed consent. } \\
\text { Male: } 56 \% \text {; mean age: } 55 \text { years. } \\
\text { Excluded: usual contraindications for axillary nerve blockade and regional anaesthesia. } \\
\text { Motor or sensory disease of limb involved in surgical procedure. Non-palpable axillary } \\
\text { artery pulse. }\end{array}$ \\
\hline
\end{tabular}

Interventions

Multiple (musculocutaneous, radial, median and ulnar nerves) versus multiple (triple: musculocutaneous + two of radial/ median/ ulnar nerves) versus double (two of radial/ median/ ulnar nerves) versus

double (musculocutaneous + radial/ median/ ulnar nerve) versus single (radial/ median/ ulnar nerve) injection.

All received local anaesthetic (LA) solution: $40 \mathrm{ml}$ mepivacaine $1 \%$.

Oral premedication with lorazepam $1 \mathrm{mg}$ and sedation with IV midazolam. One anaesthetist performed all the blocks. After locating the axillary artery in the axilla, lidocaine $1 \%$ injected subcutaneously over the arterial pulse. A 22 gauge $50 \mathrm{~mm}$ long insulated needle connected to nerve stimulator was used to locate the nerves.

1. Multiple injection: to musculocutaneous, radial, median and ulnar nerves.

2. Multiple injection: to musculocutaneous nerve $(10 \mathrm{ml} \mathrm{LA})$ and either to the radial and median nerves or the radial and ulnar nerves or the median and ulnar nerves.

3. Double injection: to the radial and median nerves or the radial and ulnar nerves or the median and ulnar nerves.

4. Double injection: to musculocutaneous nerve $(10 \mathrm{ml} \mathrm{LA})$ and either to the radial, median or ulnar nerve.

5. Single injection: to the radial or median or ulnar nerve.

Outcomes

Length of follow-up: 3 months surgical follow-up (also 24 hours) for adverse neurological outcomes; onset of sensory block assessed every 10 minutes, 40 minutes; also duration of block.

Sensory blockade

Motor blockade 


\begin{tabular}{ll} 
Anaesthesia failure (incomplete sensory blockade, incomplete motor blockade) \\
Time for block \\
Duration of sensory blockade \\
$\begin{array}{l}\text { Duration of tourniquet use } \\
\text { Tourniquet discomfort } \\
\text { Problems (during injection) } \\
\text { Long term neurological complication } \\
\text { Participant opinion of technique }\end{array}$ \\
\hline $\begin{array}{l}\text { Part translation from Spanish provided by co-author }(\mathrm{SR}) . \\
\text { Response to request for details of methods, trial setting and use of intra-operative opioids } \\
\text { and sedatives received from Dr Serradell Catalan on } 03 / 02 / 05 .\end{array}$ \\
$\begin{array}{l}\text { The ASA (American Society of Anesthesiologists) physical status classification is a system } \\
\text { for assessing the fitness of patients before surgery. It has five categories }(1-5): 1=\text { healthy, } \\
2=\text { mild systemic disease, } 3=\text { severe systemic disease, } 4=\text { severe disease that is a constant } \\
\text { threat to life, } 5=\text { moribund. }\end{array}$ \\
\hline
\end{tabular}

Risk of bias

\begin{tabular}{|c|c|c|}
\hline Bias & Authors' judgement & Support for judgement \\
\hline $\begin{array}{l}\text { Random sequence generation (selection } \\
\text { bias) }\end{array}$ & Low risk & $\begin{array}{l}\text { "A computer-generated table of random } \\
\text { numbers." }\end{array}$ \\
\hline Allocation concealment (selection bias) & High risk & "read off the allocation from a list." \\
\hline $\begin{array}{l}\text { Blinding (performance bias and detection } \\
\text { bias) } \\
\text { All outcomes }\end{array}$ & Low risk & $\begin{array}{l}\text { "Single blind" Blinded doctor for motor } \\
\text { and sensory block evaluation. }\end{array}$ \\
\hline $\begin{array}{l}\text { Incomplete outcome data (attrition bias) } \\
\text { All outcomes }\end{array}$ & Low risk & No loss to follow-up. \\
\hline Selective reporting (reporting bias) & Unclear risk & $\begin{array}{l}\text { Possible but no protocol available. There } \\
\text { was a sample size calculation. }\end{array}$ \\
\hline Balance in baseline characteristics? & Unclear risk & $\begin{array}{l}\text { Yes, aside from the distribution of the var- } \\
\text { ious operations, which were upper limb } \\
\text { (forearm, wrist or hand) post-traumatic or- } \\
\text { thopaedic surgery. }\end{array}$ \\
\hline Free from performance bias? & Low risk & $\begin{array}{l}\text { All blocks were performed by the same doc- } \\
\text { tor. Other care seemed comparable. }\end{array}$ \\
\hline
\end{tabular}




\begin{tabular}{ll} 
Methods & $\begin{array}{l}\text { Method of randomization: not stated. } \\
\text { Double-blind. } \\
\text { Blinded outcome assessor. } \\
\text { No loss to follow-up (assumed for } 30 \text { days follow-up). }\end{array}$ \\
\hline Participants & $\begin{array}{l}\text { Florence, Italy } \\
\text { Period of study: } 2000 \text { ? } \\
100 \text { people undergoing elective upper limb surgery in hand, wrist or forearm. Informed } \\
\text { consent. } \\
\text { Male: } 55 \% \text { mean age: } 41.5 \text { years. } \\
\text { Excluded: ASA physical status }>2 \text { (see notes). }\end{array}$ \\
\hline $\begin{array}{l}\text { Multiple versus double injection (both groups using neurostimulation method). } \\
\text { All received local anaesthetic (LA) solution: lidocaine } 2 \% \text { and bupivacaine } 0.5 \% \text { in } 1: \\
1 \text { ratio. Nerve blockade facilitated using } 22 \mathrm{G} \text { insulated short-bevelled needle and nerve } \\
\text { stimulator. All blocks carried out by one operator. } \\
\text { All received IV midazolam (sedation) and fentanyl } 5 \text { minutes before block. Initial subcu- } \\
\text { taneous injection of } 4 \text { ml LA to anaesthetise medial cutaneous nerves of arm or forearm. } \\
1 . \text { Multiple (triple) injection: injection of } 10 \text { ml LA to musculocutaneous nerve; then } \\
10 \text { ml to median nerve and } 20 \text { ml to radial nerve. } \\
\text { 2. Double injection: injection of } 20 \text { ml LA to median nerve; then } 20 \text { ml to radial nerve. }\end{array}$ \\
\hline
\end{tabular}

Outcomes
Request for details of method of randomization, types of surgery and some of the results sent to Dr Sia on 09/11/04.

The ASA (American Society of Anesthesiologists) physical status classification is a system for assessing the fitness of patients before surgery. It has five categories (1-5): $1=$ healthy, $2=$ mild systemic disease, $3=$ severe systemic disease, $4=$ severe disease that is a constant threat to life, $5=$ moribund.

\section{Risk of bias}

\begin{tabular}{|c|c|c|}
\hline Bias & Authors' judgement & Support for judgement \\
\hline $\begin{array}{l}\text { Random sequence generation (selection } \\
\text { bias) }\end{array}$ & Unclear risk & $\begin{array}{l}\text { "One hundred patients were randomly al- } \\
\text { located to } 2 \text { groups." No details of method. }\end{array}$ \\
\hline
\end{tabular}


Sia 2001 (Continued)

\begin{tabular}{|c|c|c|}
\hline Allocation concealment (selection bias) & Unclear risk & No information. \\
\hline $\begin{array}{l}\text { Blinding (performance bias and detection } \\
\text { bias) } \\
\text { All outcomes }\end{array}$ & Low risk & $\begin{array}{l}\text { "double-blind study"; "All blocks .... were } \\
\text { assessed by an investigator unaware of } \\
\text { group assignment." }\end{array}$ \\
\hline $\begin{array}{l}\text { Incomplete outcome data (attrition bias) } \\
\text { All outcomes }\end{array}$ & Low risk & $\begin{array}{l}\text { No loss of follow-up apparent for block per- } \\
\text { formance. }\end{array}$ \\
\hline Selective reporting (reporting bias) & Unclear risk & $\begin{array}{l}\text { Possible but no protocol available. The se- } \\
\text { lection of primary outcome for sample size } \\
\text { calculation of the blocking of the muscu- } \\
\text { locutaneous nerve is unusual. }\end{array}$ \\
\hline Balance in baseline characteristics? & Unclear risk & $\begin{array}{l}\text { Yes, aside from the distribution of the var- } \\
\text { ious operations, which were elective fore- } \\
\text { arm, wrist or hand surgery. }\end{array}$ \\
\hline Free from performance bias? & Low risk & $\begin{array}{l}\text { "All blocks were performed or supervised } \\
\text { by the first author." Other care seemed } \\
\text { comparable. }\end{array}$ \\
\hline
\end{tabular}

\section{Sia 2010a}

\begin{tabular}{ll} 
Methods & $\begin{array}{l}\text { Method of randomization: computer-generated randomization list. } \\
\text { Blinded outcome assessor. } \\
\text { No loss to follow-up (14 patients - distributed between the three trials Sia } 2010 \text { a,b+c - } \\
\text { were excluded after randomization because of inability to locate the desired nerves). }\end{array}$ \\
\hline Participants & $\begin{array}{l}\text { Florence, Italy } \\
\text { Period of study: } 2005 \text { to } 2008 . \\
138 \text { people undergoing surgery on the fifth finger (fractures, neoformations, tendon } \\
\text { injuries) and on the fifth metacarpal bone. Informed consent. } \\
\text { Male: } 56.5 \% \text { mean age: } 44 \text { years. } \\
\text { Excluded: ASA physical status }>2 \text { (see notes) }\end{array}$ \\
\hline Interventions & $\begin{array}{l}\text { Multiple (triple) versus single (ulnar) injection (both groups using neurostimulation } \\
\text { method). } \\
\text { All received local anaesthetic (LA) solution: lidocaine } 2 \% \text { and bupivacaine } 0.5 \% \text { in } 1: 1 \\
\text { ratio; total volume } 40 \text { ml. Nerve blockade facilitated using } 22 \mathrm{G} \text { insulated short-bevelled } \\
\text { needle and nerve stimulator. All blocks carried out by one experienced operator. } \\
\text { All received IV midazolam } 20 \mu \mathrm{gg} / \mathrm{kg} \text { and fentanyl } 1 \mu \mathrm{gg} / \mathrm{kg} 5 \text { minutes before block. } \\
\text { Initial subcutaneous injection of } 4 \mathrm{ml} \mathrm{LA} \text { over the axillary artery to anaesthetise medial } \\
\text { cutaneous nerves of arm and forearm. } \\
\text { 1. Multiple (triple) injection: injection of } 10 \text { ml LA to median nerve; } 6 \text { ml to musculo- } \\
\text { cutaneous nerve and } 20 \mathrm{ml} \text { to radial nerve. } \\
\text { 2. Single injection: injection of } 36 \mathrm{ml} \mathrm{LA} \text { to ulnar nerve. }\end{array}$ \\
\hline
\end{tabular}




\begin{tabular}{ll} 
Lutcomes & Length of follow-up: 30 minutes for sensory and motor block; 48 hours for nerve injury; \\
neurological sequelae at 10 and 30 days. \\
Sensory blockade \\
Motor blockade \\
Analgesic failure (use of supplementary anaesthesia; use of opioids for tourniquet pain \\
in operation area) \\
Block performance time \\
Block onset time \\
Time to readiness for surgery \\
Duration of surgery \\
Duration of tourniquet use \\
Tourniquet discomfort and pain \\
Need for intraoperative sedation \\
Problems (during injection and operation) \\
Long-term neurological complication (none) \\
\hline
\end{tabular}

Request for clarification on patient enrolment and additional data on complications sent to Dr Salvatore Sia on 14/10/2010; reply received 06/11/2010.

Although the Results section for the 3 trials states that 6 patients were excluded in the triple injections groups (TNS) and 8 patients in single injection groups (SEL), Dr Sia clarified in a personal communication that these were treated as "pre-operative" dropouts and were replaced by other patients.

The ASA (American Society of Anesthesiologists) physical status classification is a system for assessing the fitness of patients before surgery. It has five categories (1-5): $1=$ healthy, 2 = mild systemic disease, 3 = severe systemic disease, $4=$ severe disease that is a constant threat to life, $5=$ moribund.

\section{Risk of bias}

\begin{tabular}{|c|c|c|}
\hline Bias & Authors' judgement & Support for judgement \\
\hline $\begin{array}{l}\text { Random sequence generation (selection } \\
\text { bias) }\end{array}$ & Low risk & $\begin{array}{l}\text { "Patients undergoing each type of surgery } \\
\text { were randomly assigned by a computer- } \\
\text { generated list ..." }\end{array}$ \\
\hline Allocation concealment (selection bias) & Unclear risk & Allocation concealment was not stated. \\
\hline $\begin{array}{l}\text { Blinding (performance bias and detection } \\
\text { bias) } \\
\text { All outcomes }\end{array}$ & Low risk & $\begin{array}{l}\text { Patients - not blinded. Caregiver - un- } \\
\text { blinded. Assessors - blinded. "All the blocks } \\
\text { were... assessed by a blinded investigator." } \\
\text { Blinding is within study limitations. }\end{array}$ \\
\hline $\begin{array}{l}\text { Incomplete outcome data (attrition bias) } \\
\text { All outcomes }\end{array}$ & Unclear risk & $\begin{array}{l}\text { "Six patients in group TNS and } 8 \text { in group } \\
\text { SEL were excluded from the study because } \\
\text { all the prearranged nerves were not located } \\
\text { by nerve stimulation." Personal communi- } \\
\text { cation from the author indicates that these } \\
\text { were post-randomization exclusions. }\end{array}$ \\
\hline
\end{tabular}




\begin{tabular}{l|l|l}
\hline Selective reporting (reporting bias) & Low risk & $\begin{array}{l}\text { No protocol but same plan for series of } \\
\text { trials. Clearly reported primary outcomes. } \\
\text { Ethics committee acceptance reported. }\end{array}$ \\
\hline Balance in baseline characteristics? & Low risk & Balanced. \\
\hline Free from performance bias? & Unclear risk & $\begin{array}{l}\text { All the blocks were performed or super- } \\
\text { vised by the first author, however the num- } \\
\text { ber and experienced level of supervised care } \\
\text { providers is not stated. }\end{array}$ \\
\hline
\end{tabular}

\section{Sia $2010 b$}

\begin{tabular}{|c|c|}
\hline Methods & $\begin{array}{l}\text { Method of randomization: computer-generated randomization list. } \\
\text { Blinded outcome assessor. } \\
\text { No loss to follow-up ( } 14 \text { patients - distributed between the three trials Sia } 2010 \text { a,b+c } \\
\text { were excluded after randomization because of inability to locate the desired nerves). }\end{array}$ \\
\hline Participants & $\begin{array}{l}\text { Florence, Italy } \\
\text { Period of study: } 2005 \text { to } 2008 \text {. } \\
138 \text { people undergoing superficial surgery (without bone involvement) on the palm (e.g., } \\
\text { Dupuytren contracture, tendons or nerve injuries, neoformations) or on the dorsum of } \\
\text { the hand (e.g., cysts, neoformations, pathologies of extensor tendons). Informed consent. } \\
\text { Male: } 45 \% \text {; mean age: } 49.5 \text { years. } \\
\text { Excluded: ASA physical status }>2 \text { (see notes). }\end{array}$ \\
\hline Interventions & $\begin{array}{l}\text { Multiple (triple) versus double (median and ulnar) injection. } \\
\text { All received local anaesthetic (LA) solution: lidocaine } 2 \% \text { and bupivacaine } 0.5 \% \text { in } 1: 1 \\
\text { ratio; total volume } 40 \mathrm{ml} \text {. Nerve blockade facilitated using } 22 \mathrm{G} \text { insulated short-bevelled } \\
\text { needle and nerve stimulator. All blocks carried out by one experienced operator. } \\
\text { All received IV midazolam } 20 \mathrm{mcg} / \mathrm{kg} \text { and fentanyl } 1 \mathrm{mcg} / \mathrm{kg} 5 \text { minutes before block. } \\
\text { Initial subcutaneous injection of } 4 \mathrm{ml} \mathrm{LA} \text { over the axillary artery to anaesthetise medial } \\
\text { cutaneous nerves of arm and forearm. } \\
\text { 1. Multiple (triple) injection: injection of } 10 \mathrm{ml} \mathrm{LA} \text { to median nerve; } 6 \mathrm{ml} \text { to musculo- } \\
\text { cutaneous nerve and } 20 \mathrm{ml} \text { to radial nerve. } \\
\text { 2. Double injection: injection of } 18 \mathrm{ml} \mathrm{LA} \mathrm{to} \mathrm{ulnar} \mathrm{nerve,} \mathrm{injection} \mathrm{of} 18 \mathrm{ml} \mathrm{LA} \mathrm{to} \\
\text { median nerve. }\end{array}$ \\
\hline Outcomes & $\begin{array}{l}\text { Length of follow-up: } 30 \text { minutes for sensory and motor block; } 48 \text { hours for nerve injury; } \\
\text { neurological sequelae at } 10 \text { and } 30 \text { days. } \\
\text { Sensory blockade } \\
\text { Motor blockade } \\
\text { Analgesic failure (use of supplementary anaesthesia; use of opioids for tourniquet pain } \\
\text { in operation area) } \\
\text { Block performance time } \\
\text { Block onset time } \\
\text { Time to readiness for surgery } \\
\text { Duration of surgery }\end{array}$ \\
\hline
\end{tabular}




\begin{tabular}{|c|c|}
\hline & $\begin{array}{l}\text { Duration of tourniquet use } \\
\text { Tourniquet discomfort and pain } \\
\text { Need for intraoperative sedation } \\
\text { Problems (during injection and operation) } \\
\text { Long-term neurological complication (none) }\end{array}$ \\
\hline Notes & $\begin{array}{l}\text { Request for clarification on patient enrolment and additional data on complications sent } \\
\text { to Dr Salvatore Sia on } 14 / 10 / 2010 \text {; reply received } 06 / 11 / 2010 \text {. } \\
\text { Although the Results section for the } 3 \text { trials states that } 6 \text { patients were excluded in the } \\
\text { triple injections groups (TNS) and } 8 \text { patients in single injection groups (SEL), Dr Sia } \\
\text { clarified in a personal communication that these were treated as "pre-operative" dropouts } \\
\text { and were replaced by other patients. } \\
\text { The ASA (American Society of Anesthesiologists) physical status classification is a system } \\
\text { for assessing the fitness of patients before surgery. It has five categories (1-5): } 1 \text { = healthy, } \\
2=\text { mild systemic disease, } 3 \text { = severe systemic disease, } 4=\text { severe disease that is a constant } \\
\text { threat to life, } 5=\text { moribund. }\end{array}$ \\
\hline
\end{tabular}

Risk of bias

\begin{tabular}{|c|c|c|}
\hline Bias & Authors' judgement & Support for judgement \\
\hline $\begin{array}{l}\text { Random sequence generation (selection } \\
\text { bias) }\end{array}$ & Low risk & $\begin{array}{l}\text { "Patients undergoing each type of surgery } \\
\text { were randomly assigned by a computer- } \\
\text { generated list ..." }\end{array}$ \\
\hline Allocation concealment (selection bias) & Unclear risk & Allocation concealment was not stated. \\
\hline $\begin{array}{l}\text { Blinding (performance bias and detection } \\
\text { bias) } \\
\text { All outcomes }\end{array}$ & Low risk & $\begin{array}{l}\text { Patients - not blinded. Caregiver - un- } \\
\text { blinded. Assessors - blinded. "All the blocks } \\
\text { were... assessed by a blinded investigator." } \\
\text { Blinding is within study limitations. }\end{array}$ \\
\hline $\begin{array}{l}\text { Incomplete outcome data (attrition bias) } \\
\text { All outcomes }\end{array}$ & Unclear risk & $\begin{array}{l}\text { "Six patients in group TNS and } 8 \text { in group } \\
\text { SEL were excluded from the study because } \\
\text { all the prearranged nerves were not located } \\
\text { by nerve stimulation." Personal communi- } \\
\text { cation from the author indicates that these } \\
\text { were post-randomization exclusions. }\end{array}$ \\
\hline Selective reporting (reporting bias) & Low risk & $\begin{array}{l}\text { No protocol but same plan for series of } \\
\text { trials. Clearly reported primary outcomes. } \\
\text { Ethics committee acceptance reported. }\end{array}$ \\
\hline Balance in baseline characteristics? & Low risk & Balanced. \\
\hline Free from performance bias? & Unclear risk & $\begin{array}{l}\text { All the blocks were performed or super- } \\
\text { vised by the first author, however the num- } \\
\text { ber and experienced level of supervised care } \\
\text { providers is not stated. }\end{array}$ \\
\hline
\end{tabular}


Methods

Participants
Method of randomization: computer-generated randomization list.

Blinded outcome assessor.

No loss to follow-up (14 patients - distributed between the three trials Sia 2010 a,b+c were excluded after randomization because of inability to locate the desired nerves).

Florence, Italy

Period of study: 2005 to 2008.

138 people undergoing any surgery on the first three fingers in which only 1 or 2 nerves were involved. Informed consent.

Male: $52 \%$; mean age: 45.5 years.

Exclued: ASA physical status $>2$ (see notes).
Multiple (triple) versus double (median and radial) injection.

All received local anaesthetic (LA) solution: lidocaine $2 \%$ and bupivacaine $0.5 \%$ in $1: 1$ ratio; total volume $40 \mathrm{ml}$. Nerve blockade facilitated using $22 \mathrm{G}$ insulated short-bevelled needle and nerve stimulator. All blocks carried out by one experienced operator.

All received IV midazolam $20 \mu \mathrm{g} / \mathrm{kg}$ and fentanyl $1 \mu \mathrm{g} / \mathrm{kg} 5$ minutes before block. Initial subcutaneous injection of $4 \mathrm{ml} \mathrm{LA}$ over the axillary artery to anaesthetise medial cutaneous nerves of arm and forearm.

1. Multiple (triple) injection: injection of $10 \mathrm{ml}$ LA to median nerve; $6 \mathrm{ml}$ to musculocutaneous nerve and $20 \mathrm{ml}$ to radial nerve.

2. Double injection: injection of $18 \mathrm{ml} \mathrm{LA}$ to median nerve, and injection of $18 \mathrm{ml} \mathrm{LA}$ to radial nerve.
Outcomes
Length of follow-up: 30 minutes for sensory and motor block; 48 hours for nerve injury; neurological sequelae at 10 and 30 days.

Sensory blockade

Motor blockade

Analgesic failure (use of supplementary anaesthesia; use of opioids for tourniquet pain in operation area)

Block performance time

Block onset time

Time to readiness for surgery

Duration of surgery

Duration of tourniquet use

Tourniquet discomfort and pain

Need for intraoperative sedation

Problems (during injection and operation)

Long-term neurological complication (none)

\begin{tabular}{|c|c|}
\hline Notes & $\begin{array}{l}\text { Request for clarification on patient enrolment and additional data on complications sent } \\
\text { to Dr Salvatore Sia on } 14 / 10 / 2010 \text {; reply received } 06 / 11 / 2010 \text {. } \\
\text { Although the Results section for the } 3 \text { trials states that } 6 \text { patients were excluded in the } \\
\text { triple injections groups (TNS) and } 8 \text { patients in single injection groups (SEL), Dr Sia } \\
\text { clarified in a personal communication that these were treated as "pre-operative" dropouts } \\
\text { and were replaced by other patients. } \\
\text { The ASA (American Society of Anesthesiologists) physical status classification is a system } \\
\text { for assessing the fitness of patients before surgery. It has five categories (1-5): } 1 \text { = healthy, }\end{array}$ \\
\hline
\end{tabular}

Single, double or multiple-injection techniques for axillary brachial plexus block for hand, wrist or forearm surgery in adults (Review)

Copyright (C) 201 I The Cochrane Collaboration. Published by John Wiley \& Sons, Ltd. 
$2=$ mild systemic disease, $3=$ severe systemic disease, $4=$ severe disease that is a constant threat to life, $5=$ moribund.

\section{Risk of bias}

\begin{tabular}{|c|c|c|}
\hline Bias & Authors' judgement & Support for judgement \\
\hline $\begin{array}{l}\text { Random sequence generation (selection } \\
\text { bias) }\end{array}$ & Low risk & $\begin{array}{l}\text { "Patients undergoing each type of surgery } \\
\text { were randomly assigned by a computer- } \\
\text { generated list ..." }\end{array}$ \\
\hline Allocation concealment (selection bias) & Unclear risk & Allocation concealment was not stated. \\
\hline $\begin{array}{l}\text { Blinding (performance bias and detection } \\
\text { bias) } \\
\text { All outcomes }\end{array}$ & Low risk & $\begin{array}{l}\text { Patients - not blinded. Caregiver - un- } \\
\text { blinded. Assessors - blinded. "All the blocks } \\
\text { were... assessed by a blinded investigator." } \\
\text { Blinding is within study limitations. }\end{array}$ \\
\hline $\begin{array}{l}\text { Incomplete outcome data (attrition bias) } \\
\text { All outcomes }\end{array}$ & Unclear risk & $\begin{array}{l}\text { "Six patients in group TNS and } 8 \text { in group } \\
\text { SEL were excluded from the study because } \\
\text { all the prearranged nerves were not located } \\
\text { by nerve stimulation." Personal communi- } \\
\text { cation from the author indicates that these } \\
\text { were post-randomization exclusions. }\end{array}$ \\
\hline Selective reporting (reporting bias) & Low risk & $\begin{array}{l}\text { No protocol but same plan for series of } \\
\text { trials. Clearly reported primary outcomes. } \\
\text { Ethics committee acceptance reported. }\end{array}$ \\
\hline Balance in baseline characteristics? & Low risk & Balanced. \\
\hline Free from performance bias? & Unclear risk & $\begin{array}{l}\text { All the blocks were performed or super- } \\
\text { vised by the first author, however the num- } \\
\text { ber and experienced level of supervised care } \\
\text { providers is not stated. }\end{array}$ \\
\hline
\end{tabular}

Turkan 2002

\begin{tabular}{ll} 
Methods & $\begin{array}{l}\text { Method of randomization: not stated. } \\
\text { Blinded outcome assessor. } \\
\text { No loss to follow-up apparent. }\end{array}$ \\
\hline Participants & Ankara, Turkey \\
& $\begin{array}{l}\text { Period of study: not stated. } \\
69 \text { people undergoing orthopedic or trauma surgery of the upper extremity (not otherwise } \\
\text { specified). Informed consent. } \\
\text { Male: } 75 \% \text {; mean age: } 49 \text { years. } \\
\text { Excluded: ASA physical status }>2 \text { (see notes). }\end{array}$
\end{tabular}


Turkan 2002 (Continued)

\begin{tabular}{|c|c|}
\hline Interventions & $\begin{array}{l}\text { Double versus single (Winnie's technique) versus single (transarterial) injection. } \\
\text { All received local anaesthetic (LA) solution: } 2 \% \text { prilocaine and } 0.5 \% \text { bupivacaine in } 1 \text { : } \\
1 \text { ratio; total volume } 40 \mathrm{ml} \text {. Identity of operators performing block were not specified; } \\
\text { but they were described as experienced. } \\
\text { Sedative premedication with } 0.15 \mathrm{mg} / \mathrm{kg} \text { of IM midazolam. } \\
\text { 1. Double injection: injection of } 20 \mathrm{ml} \text { using Winnie's technique (endpoint of fascial } \\
\text { click and paraesthesia in hand or forearm), and injection of } 20 \mathrm{ml} \text { using transarterial } \\
\text { technique posterior to the axillary artery. } \\
\text { 2. Single injection: injection of } 40 \mathrm{ml} \text { using Winnie's technique (endpoint of fascial click } \\
\text { and paraesthesia in hand or forearm). } \\
\text { 3. Single injection: injection of } 40 \mathrm{ml} \text { using transarterial technique posterior to the } \\
\text { axillary artery. } \\
\text { When patient in extreme anxiety or block was incomplete, propofol ( } \leq 3 \mathrm{mg} / \mathrm{kg} \text { ) and/ } \\
\text { or fentanyl }(\leq 1 \mu \mathrm{g} / \mathrm{kg} \text { ) was administered intraoperatively. }\end{array}$ \\
\hline Outcomes & $\begin{array}{l}\text { Length of follow-up: sensory and motor block assessed at 10, } 20 \text { and } 30 \text { minutes. } \\
\text { Sensory blockade } \\
\text { Analgesic failure (use of supplementary anaesthesia) } \\
\text { Tourniquet discomfort and pain }\end{array}$ \\
\hline Notes & $\begin{array}{l}\text { The ASA (American Society of Anesthesiologists) physical status classification is a system } \\
\text { for assessing the fitness of patients before surgery. It has five categories }(1-5): 1=\text { healthy, } \\
2=\text { mild systemic disease, } 3=\text { severe systemic disease, } 4=\text { severe disease that is a constant } \\
\text { threat to life, } 5=\text { moribund. }\end{array}$ \\
\hline
\end{tabular}

Risk of bias

\begin{tabular}{|c|c|c|}
\hline Bias & Authors' judgement & Support for judgement \\
\hline $\begin{array}{l}\text { Random sequence generation (selection } \\
\text { bias) }\end{array}$ & Unclear risk & $\begin{array}{l}\text { "The patients were divided randomly into } \\
\text { three groups..". No further details given. }\end{array}$ \\
\hline Allocation concealment (selection bias) & Unclear risk & Allocation concealment not stated. \\
\hline $\begin{array}{l}\text { Blinding (performance bias and detection } \\
\text { bias) } \\
\text { All outcomes }\end{array}$ & Unclear risk & $\begin{array}{l}\text { Not stated for participants, operators. It is } \\
\text { mentioned that part of sensory testing was } \\
\text { done by a blinded surgeon, but no detail } \\
\text { given for other outcomes. }\end{array}$ \\
\hline $\begin{array}{l}\text { Incomplete outcome data (attrition bias) } \\
\text { All outcomes }\end{array}$ & Low risk & Not evident. \\
\hline Selective reporting (reporting bias) & Unclear risk & $\begin{array}{l}\text { A bit vague in definition of outcomes and } \\
\text { some of the } P \text { values seem excessive. }\end{array}$ \\
\hline Balance in baseline characteristics? & Unclear risk & $\begin{array}{l}\text { Balanced for sex, age, weight } \& \text { height but } \\
\text { no information on surgery. }\end{array}$ \\
\hline
\end{tabular}


Turkan 2002 (Continued) this.

ASA $=$ American Society of Anaesthesiologists

$\mathrm{LA}=$ local anaesthetic

$\mathrm{IV}=$ intravenous

\section{Characteristics of excluded studies [ordered by study ID]}

\begin{tabular}{|c|c|}
\hline Study & Reason for exclusion \\
\hline Bloc 2010 & Not in scope of review: use of ultrasound-guided method. \\
\hline Bouaziz 1997 & Not in scope of review: comparison of two approaches: midhumeral versus axillary. \\
\hline Carre 2000 & Not in scope of review: children only. \\
\hline Gianesello 2010 & $\begin{array}{l}\text { Not in scope of review: review of full text revealed that the study compared two different multiple-injection } \\
\text { methods. }\end{array}$ \\
\hline Imasogie 2010 & Not in scope of review: use of ultrasound-guided method. \\
\hline K-Nielsen 2000 & Not in scope of review: comparison of two approaches: subcoracoid versus axillary. \\
\hline Kjelstrup 2006 & Non randomized study. \\
\hline Liu 2005 & Not in scope of review: use of ultrasound-guided method \\
\hline Sia $2001 b$ & Not in scope of review: both interventions tested belonged to the multiple-injection group. \\
\hline Singelyn 1992 & Not in scope of review: single injection in both groups. \\
\hline Sites 2006 & Not in scope of review: use of ultrasound-guided method. \\
\hline Tuominen 1987 & Not in scope of review: review of the full text revealed that these were both single-injection techniques. \\
\hline Vester-Andersen 1984 & Not in scope of review: single injection into the same site via indwelling catheter. \\
\hline Vester-Andersen 1986 & Not in scope of review: single injection into the same site via indwelling catheter. \\
\hline Youssef 1988 & Not in scope of review: review of the full text revealed that these were both single-injection techniques. \\
\hline
\end{tabular}




\section{Characteristics of studies awaiting assessment [ordered by study ID]}

\section{Ramirez-Gomez 2010}

\begin{tabular}{|c|c|}
\hline Methods & Randomized controlled trial. \\
\hline Participants & 50 adult patients undergoing trauma surgery of the arm. \\
\hline Interventions & Multiple-injection technique compared with single-injection technique; both guided by neurostimulation. \\
\hline Outcomes & $\begin{array}{l}\text { 1. Surgical anaesthesia } \\
\text { 2. Sensory block } \\
\text { 3. Motor block } \\
\text { 4. Duration of post-operative analgesia }\end{array}$ \\
\hline Notes & Study, which is published in Spanish, was identified by an EMBASE search conducted in March 2011. \\
\hline
\end{tabular}


DATA AND ANALYSES

\section{Comparison 1. Double versus single-injection technique}

\begin{tabular}{|c|c|c|c|c|}
\hline Outcome or subgroup title & $\begin{array}{l}\text { No. of } \\
\text { studies }\end{array}$ & $\begin{array}{c}\text { No. of } \\
\text { participants }\end{array}$ & Statistical method & Effect size \\
\hline $\begin{array}{l}1 \text { Primary anaesthesia failure } \\
\text { (incomplete sensory block) }\end{array}$ & 8 & 497 & Risk Ratio (M-H, Random, 95\% CI) & $0.51[0.30,0.85]$ \\
\hline $\begin{array}{l}\text { 1.1 Transarterial injection (for } \\
\text { double injection) }\end{array}$ & 4 & 237 & Risk Ratio (M-H, Random, 95\% CI) & $0.72[0.33,1.58]$ \\
\hline $\begin{array}{l}1.2 \text { Location by } \\
\text { neurostimulation (for double } \\
\text { injection) }\end{array}$ & 4 & 260 & Risk Ratio (M-H, Random, 95\% CI) & $0.40[0.22,0.73]$ \\
\hline $\begin{array}{l}2 \text { Primary anaesthesia failure } \\
\text { - subgrouped by outcome } \\
\text { definition }\end{array}$ & 8 & & Risk Ratio (M-H, Random, 95\% CI) & Subtotals only \\
\hline $\begin{array}{l}2.1 \text { Incomplete overall sensory } \\
\text { block }\end{array}$ & 4 & 238 & Risk Ratio (M-H, Random, 95\% CI) & $0.43[0.24,0.76]$ \\
\hline $\begin{array}{l}2.2 \text { Supplemental blocks for } \\
\text { surgical area }\end{array}$ & 5 & 309 & Risk Ratio (M-H, Random, 95\% CI) & $0.43[0.17,1.11]$ \\
\hline $\begin{array}{l}3 \text { Complete failure of block: } \\
\text { general anaesthesia or new } \\
\text { plexus block }\end{array}$ & 6 & 338 & Risk Ratio (M-H, Fixed, 95\% CI) & $1.29[0.33,5.01]$ \\
\hline 4 Incomplete motor block & 4 & 229 & Risk Ratio (M-H, Fixed, 95\% CI) & $0.78[0.58,1.03]$ \\
\hline 5 Secondary analgesia failure & 4 & & Risk Ratio (M-H, Fixed, 95\% CI) & Subtotals only \\
\hline $\begin{array}{l}\text { 5.1 Pain in surgical } \\
\text { site/operative field }\end{array}$ & 3 & 160 & Risk Ratio (M-H, Fixed, 95\% CI) & $0.56[0.25,1.25]$ \\
\hline 5.2 Tourniquet pain & 2 & 104 & Risk Ratio (M-H, Fixed, 95\% CI) & $0.58[0.22,1.52]$ \\
\hline 5.3 Intra-operative sedatives & 2 & 129 & Risk Ratio (M-H, Fixed, 95\% CI) & $0.64[0.31,1.31]$ \\
\hline 6 Timing (in minutes) & 4 & & Mean Difference (IV, Fixed, 95\% CI) & Subtotals only \\
\hline 6.1 Time for block & 1 & 60 & Mean Difference (IV, Fixed, 95\% CI) & $1.65[0.72,2.58]$ \\
\hline 6.2 Duration of operation & 1 & 50 & Mean Difference (IV, Fixed, 95\% CI) & $9.0[-8.19,26.19]$ \\
\hline 6.3 Duration of tourniquet & 3 & 154 & Mean Difference (IV, Fixed, 95\% CI) & $2.44[-5.24,10.13]$ \\
\hline 6.4 Duration of block & 2 & 129 & Mean Difference (IV, Fixed, 95\% CI) & $11.98[-6.73,30.68]$ \\
\hline $\begin{array}{l}7 \text { Complications during nerve } \\
\text { block }\end{array}$ & 3 & & Risk Ratio (M-H, Fixed, 95\% CI) & Subtotals only \\
\hline 7.1 Arterial puncture & 2 & 110 & Risk Ratio (M-H, Fixed, 95\% CI) & $0.0[0.0,0.0]$ \\
\hline 7.2 Venous puncture & 2 & 110 & Risk Ratio (M-H, Fixed, 95\% CI) & $1.5[0.17,13.52]$ \\
\hline 7.3 Paraesthesia & 2 & 110 & Risk Ratio (M-H, Fixed, 95\% CI) & $2.5[0.31,19.99]$ \\
\hline $\begin{array}{l}7.4 \text { Tachycardia (intra-vascular } \\
\text { injections) }\end{array}$ & 1 & 60 & Risk Ratio (M-H, Fixed, 95\% CI) & $5.86[0.25,137.66]$ \\
\hline 8 Adverse effects (> 24 hours) & 2 & & Risk Ratio (M-H, Fixed, 95\% CI) & Totals not selected \\
\hline $\begin{array}{l}9 \text { Patient discomfort and } \\
\text { dissatisfaction with method }\end{array}$ & 1 & & Risk Ratio (M-H, Fixed, 95\% CI) & Totals not selected \\
\hline 9.1 Patient uncomfortable & 1 & & Risk Ratio (M-H, Fixed, 95\% CI) & $0.0[0.0,0.0]$ \\
\hline $\begin{array}{l}\text { 9.2 Patient would not have } \\
\text { method again }\end{array}$ & 1 & & Risk Ratio (M-H, Fixed, 95\% CI) & $0.0[0.0,0.0]$ \\
\hline
\end{tabular}

Single, double or multiple-injection techniques for axillary brachial plexus block for hand, wrist or forearm surgery in adults (Review)

Copyright (C) 201 I The Cochrane Collaboration. Published by John Wiley \& Sons, Ltd. 


\begin{tabular}{|c|c|c|c|c|}
\hline Outcome or subgroup title & $\begin{array}{l}\text { No. of } \\
\text { studies }\end{array}$ & $\begin{array}{c}\text { No. of } \\
\text { participants }\end{array}$ & Statistical method & Effect size \\
\hline $\begin{array}{l}1 \text { Primary anaesthesia failure } \\
\text { (incomplete sensory block) }\end{array}$ & 7 & 632 & Risk Ratio (M-H, Random, 95\% CI) & $0.28[0.16,0.48]$ \\
\hline $\begin{array}{l}1.1 \text { No use of nerve stimulator } \\
\text { (for single injection) }\end{array}$ & 2 & 204 & Risk Ratio (M-H, Random, 95\% CI) & $0.40[0.25,0.65]$ \\
\hline $\begin{array}{l}1.2 \text { Location by } \\
\text { neurostimulation (for single } \\
\text { injection) }\end{array}$ & 5 & 428 & Risk Ratio (M-H, Random, 95\% CI) & $0.21[0.09,0.48]$ \\
\hline $\begin{array}{l}2 \text { Primary anaesthesia failure } \\
\text { - subgrouped by outcome } \\
\text { definition }\end{array}$ & 7 & & Risk Ratio (M-H, Random, 95\% CI) & Subtotals only \\
\hline $\begin{array}{l}2.1 \text { Incomplete overall sensory } \\
\text { block }\end{array}$ & 3 & 264 & Risk Ratio (M-H, Random, 95\% CI) & $0.28[0.12,0.64]$ \\
\hline $\begin{array}{l}2.2 \text { Supplemental blocks for } \\
\text { surgical area }\end{array}$ & 4 & 368 & Risk Ratio (M-H, Random, 95\% CI) & $0.26[0.11,0.63]$ \\
\hline $\begin{array}{l}3 \text { Complete failure of block: } \\
\text { general anaesthesia or new } \\
\text { plexus block }\end{array}$ & 5 & 404 & Risk Ratio (M-H, Random, 95\% CI) & $0.44[0.01,17.76]$ \\
\hline 4 Incomplete motor block & 4 & 304 & Risk Ratio (M-H, Random, 95\% CI) & $0.61[0.39,0.96]$ \\
\hline 5 Secondary analgesia failure & 5 & & Risk Ratio (M-H, Random, 95\% CI) & Subtotals only \\
\hline $\begin{array}{l}\text { 5.1 Pain in surgical } \\
\text { site/operative field }\end{array}$ & 3 & 244 & Risk Ratio (M-H, Random, 95\% CI) & $0.53[0.05,5.37]$ \\
\hline 5.2 Tourniquet pain & 4 & 379 & Risk Ratio (M-H, Random, 95\% CI) & $0.97[0.30,3.11]$ \\
\hline 5.3 Intra-operative sedatives & 5 & 482 & Risk Ratio (M-H, Random, 95\% CI) & $0.70[0.41,1.19]$ \\
\hline 6 Timing (in minutes) & 4 & & Mean Difference (IV, Random, 95\% CI) & Subtotals only \\
\hline 6.1 Time for block & 3 & 278 & Mean Difference (IV, Random, 95\% CI) & $3.34[2.66,4.03]$ \\
\hline $\begin{array}{l}6.2 \text { Time for readiness for } \\
\text { surgery }\end{array}$ & 2 & 206 & Mean Difference (IV, Random, 95\% CI) & $\begin{array}{l}-3.33[-23.23 \\
16.56]\end{array}$ \\
\hline 6.3 Duration of tourniquet & 4 & 379 & Mean Difference (IV, Random, 95\% CI) & $2.30[-2.22,6.82]$ \\
\hline 6.4 Duration of block & 1 & 60 & Mean Difference (IV, Random, 95\% CI) & $-19.5[-44.62,5.62]$ \\
\hline 6.5 Length of surgery & 1 & 138 & Mean Difference (IV, Random, 95\% CI) & $2.0[-3.53,7.53]$ \\
\hline $\begin{array}{l}7 \text { Complications during nerve } \\
\text { block }\end{array}$ & 4 & & Risk Ratio (M-H, Random, 95\% CI) & Subtotals only \\
\hline 7.1 Arterial puncture & 3 & 278 & Risk Ratio (M-H, Random, 95\% CI) & $1.90[0.64,5.66]$ \\
\hline 7.2 Venous puncture & 3 & 278 & Risk Ratio (M-H, Random, 95\% CI) & $2.58[0.89,7.48]$ \\
\hline 7.3 Paraesthesia & 4 & 382 & Risk Ratio (M-H, Random, 95\% CI) & $0.75[0.20,2.79]$ \\
\hline $\begin{array}{l}7.4 \text { Tachycardia (intra-vascular } \\
\text { injections) }\end{array}$ & 3 & 322 & Risk Ratio (M-H, Random, 95\% CI) & $0.87[0.09,8.44]$ \\
\hline $\begin{array}{l}7.5 \text { Local anaesthesia toxicity } \\
\text { (intra-arterial injections) }\end{array}$ & 1 & 104 & Risk Ratio (M-H, Random, 95\% CI) & $0.20[0.01,4.07]$ \\
\hline $\begin{array}{l}\text { 7.6 Subcutaneous/axillary } \\
\text { haematoma }\end{array}$ & 2 & 184 & Risk Ratio (M-H, Random, 95\% CI) & $0.33[0.01,7.95]$ \\
\hline 8 Adverse effects $>24$ hours & 3 & & Risk Ratio (M-H, Fixed, 95\% CI) & Totals not selected \\
\hline $\begin{array}{l}9 \text { Patient discomfort and } \\
\text { dissatisfaction with method }\end{array}$ & 2 & & Risk Ratio (M-H, Fixed, 95\% CI) & Subtotals only \\
\hline 9.1 Patient uncomfortable & 1 & 60 & Risk Ratio (M-H, Fixed, 95\% CI) & $2.0[0.77,5.20]$ \\
\hline
\end{tabular}

Single, double or multiple-injection techniques for axillary brachial plexus block for hand, wrist or forearm surgery in adults (Review)

Copyright (C) 201 I The Cochrane Collaboration. Published by John Wiley \& Sons, Ltd. 


\begin{tabular}{|c|c|c|c|c|}
\hline Outcome or subgroup title & $\begin{array}{l}\text { No. of } \\
\text { studies }\end{array}$ & $\begin{array}{c}\text { No. of } \\
\text { participants }\end{array}$ & Statistical method & Effect size \\
\hline $\begin{array}{l}1 \text { Primary anaesthesia failure } \\
\text { (incomplete sensory block) }\end{array}$ & 11 & 936 & Risk Ratio (M-H, Fixed, 95\% CI) & $0.28[0.20,0.40]$ \\
\hline $\begin{array}{l}\text { 1.1 Transarterial injection (for } \\
\text { double injection) }\end{array}$ & 3 & 270 & Risk Ratio (M-H, Fixed, 95\% CI) & $0.27[0.15,0.49]$ \\
\hline $\begin{array}{l}1.2 \text { Location by } \\
\text { neurostimulation (for double } \\
\text { injection) }\end{array}$ & 8 & 666 & Risk Ratio (M-H, Fixed, 95\% CI) & $0.28[0.18,0.44]$ \\
\hline $\begin{array}{l}2 \text { Primary anaesthesia failure } \\
\text { - subgrouped by outcome } \\
\text { definition }\end{array}$ & 11 & & Risk Ratio (M-H, Fixed, 95\% CI) & Subtotals only \\
\hline $\begin{array}{l}2.1 \text { Incomplete overall sensory } \\
\text { block }\end{array}$ & 7 & 570 & Risk Ratio (M-H, Fixed, 95\% CI) & $0.24[0.15,0.37]$ \\
\hline $\begin{array}{l}2.2 \text { Supplemental blocks for } \\
\text { surgical area }\end{array}$ & 7 & 586 & Risk Ratio (M-H, Fixed, 95\% CI) & $0.40[0.24,0.66]$ \\
\hline $\begin{array}{l}3 \text { Complete failure of block: } \\
\text { general anaesthesia or new } \\
\text { plexus block }\end{array}$ & 8 & 600 & Risk Ratio (M-H, Fixed, 95\% CI) & $0.24[0.04,1.41]$ \\
\hline 4 Incomplete motor block & 6 & 470 & Risk Ratio (M-H, Random, 95\% CI) & $0.55[0.36,0.85]$ \\
\hline 5 Secondary analgesia failure & 8 & & Risk Ratio (M-H, Fixed, 95\% CI) & Subtotals only \\
\hline $\begin{array}{l}5.1 \text { Pain in surgical } \\
\text { site/operative field }\end{array}$ & 5 & 450 & Risk Ratio (M-H, Fixed, 95\% CI) & $0.33[0.04,3.14]$ \\
\hline 5.2 Tourniquet pain & 7 & 719 & Risk Ratio (M-H, Fixed, 95\% CI) & $0.53[0.33,0.84]$ \\
\hline 5.3 Intra-operative sedatives & 7 & 716 & Risk Ratio (M-H, Fixed, 95\% CI) & $0.75[0.55,1.03]$ \\
\hline 6 Timing (in minutes) & 6 & & Mean Difference (IV, Random, 95\% CI) & Subtotals only \\
\hline 6.1 Time for block & 5 & 556 & Mean Difference (IV, Random, 95\% CI) & $1.74[1.04,2.45]$ \\
\hline $\begin{array}{l}6.2 \text { Time for readiness for } \\
\text { surgery }\end{array}$ & 5 & 524 & Mean Difference (IV, Random, 95\% CI) & $-0.08[-2.92,2.77]$ \\
\hline 6.3 Duration of tourniquet & 5 & 549 & Mean Difference (IV, Random, 95\% CI) & $2.99[-1.03,7.01]$ \\
\hline 6.4 Duration of surgery & 3 & 376 & Mean Difference (IV, Random, 95\% CI) & $0.63[-4.97,6.24]$ \\
\hline 6.5 Duration of block & 2 & 150 & Mean Difference (IV, Random, 95\% CI) & $0.89[-27.95,29.73$ \\
\hline $\begin{array}{l}7 \text { Complications during nerve } \\
\text { block }\end{array}$ & 8 & & Risk Ratio (M-H, Random, 95\% CI) & Subtotals only \\
\hline 7.1 Arterial puncture & 6 & 616 & Risk Ratio (M-H, Random, 95\% CI) & $1.37[0.66,2.84]$ \\
\hline 7.2 Venous puncture & 6 & 616 & Risk Ratio (M-H, Random, 95\% CI) & $1.28[0.75,2.17]$ \\
\hline 7.3 Paraesthesia & 7 & 716 & Risk Ratio (M-H, Random, 95\% CI) & $0.71[0.31,1.62]$ \\
\hline $\begin{array}{l}7.4 \text { Tachycardia (intra-vascular } \\
\text { injections) }\end{array}$ & 4 & 476 & Risk Ratio (M-H, Random, 95\% CI) & $0.55[0.23,1.32]$ \\
\hline $\begin{array}{l}\text { 7.5 Local anaesthesia toxicity } \\
\text { (intra-arterial injections) }\end{array}$ & 2 & 170 & Risk Ratio (M-H, Random, 95\% CI) & $1.0[0.15,6.82]$ \\
\hline $\begin{array}{l}\text { 7.6 Axillary } \\
\text { haematoma/bruises }\end{array}$ & 3 & 260 & Risk Ratio (M-H, Random, 95\% CI) & $0.30[0.09,1.06]$ \\
\hline
\end{tabular}


7.7 Accidental intravascular injection

7.8 Transient bradycardia 8 Adverse effects $>24$ hours

9 Patient discomfort and dissatisfaction with method 9.1 Patient uncomfortable 9.2 Patient would not have method again

9.3 Patient dissatisfied

\section{Analysis I.I. Comparison I Double versus single-injection technique, Outcome I Primary anaesthesia failure (incomplete sensory block).}

Review: Single, double or multiple-injection techniques for axillary brachial plexus block for hand, wrist or forearm surgery in adults

Comparison: I Double versus single-injection technique

Outcome: I Primary anaesthesia failure (incomplete sensory block)

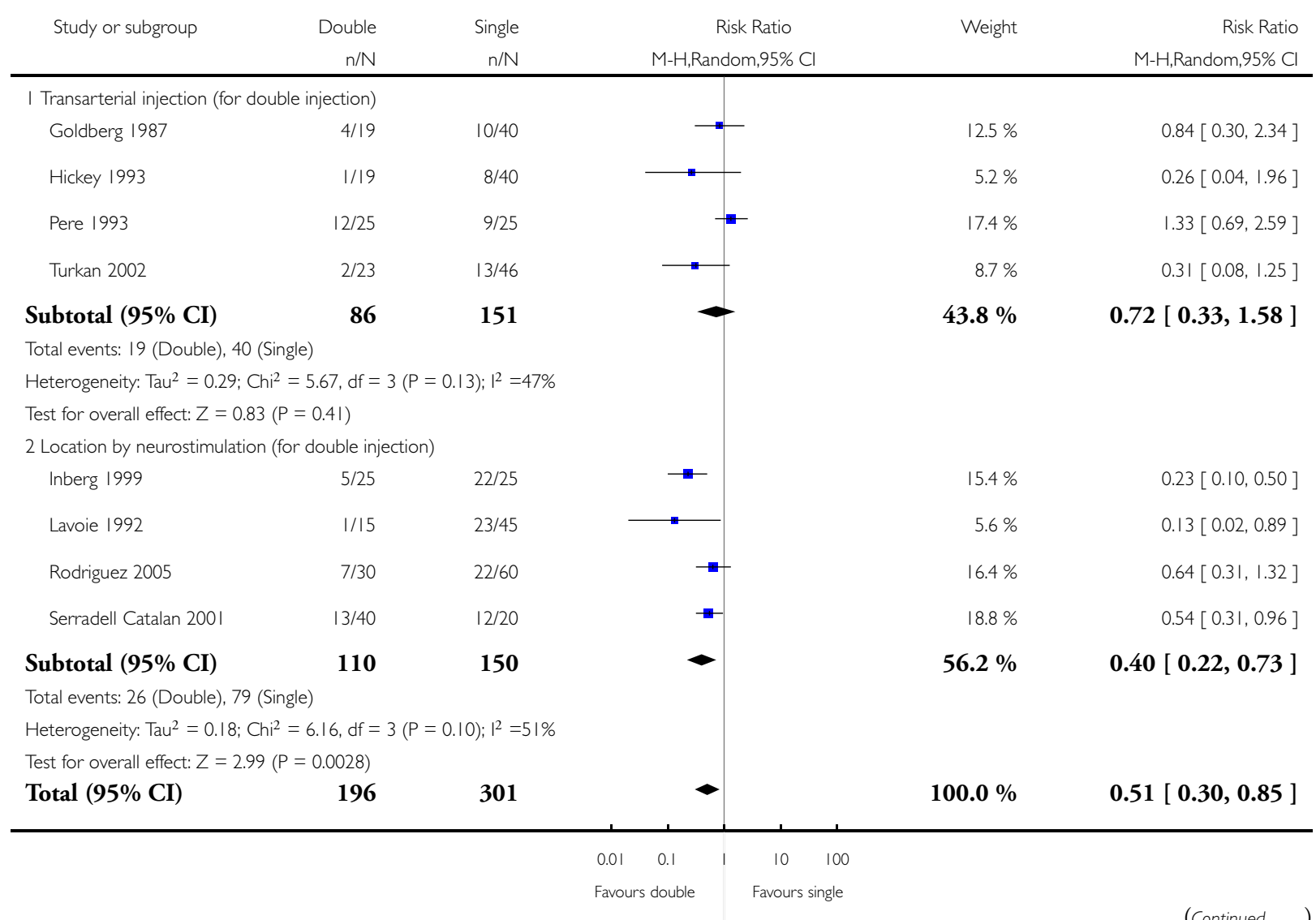




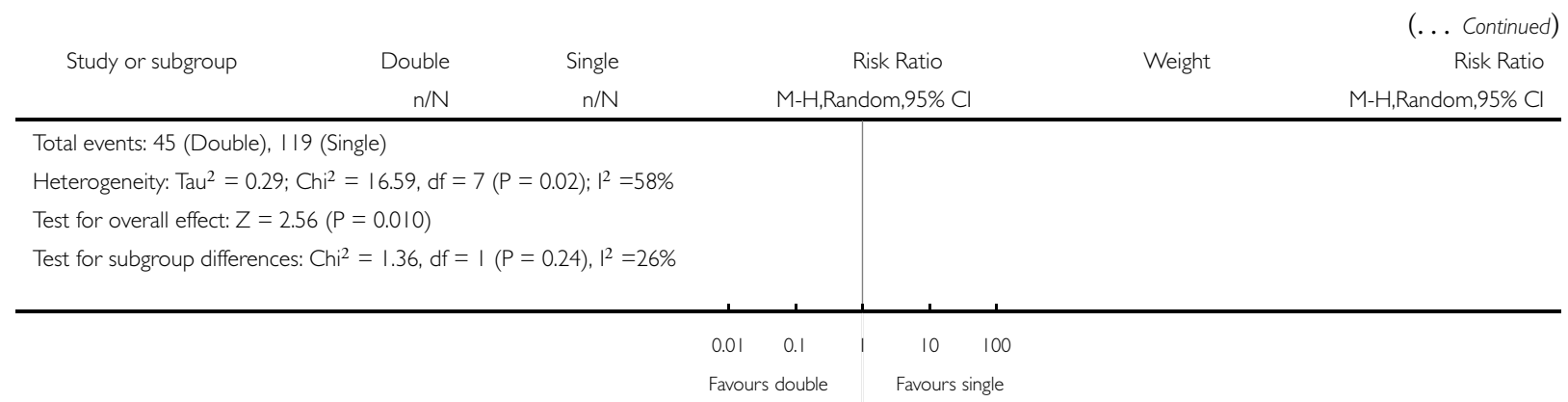

\section{Analysis I.2. Comparison I Double versus single-injection technique, Outcome 2 Primary anaesthesia} failure - subgrouped by outcome definition.

Review: Single, double or multiple-injection techniques for axillary brachial plexus block for hand, wrist or forearm surgery in adults

Comparison: I Double versus single-injection technique

Outcome: 2 Primary anaesthesia failure - subgrouped by outcome definition

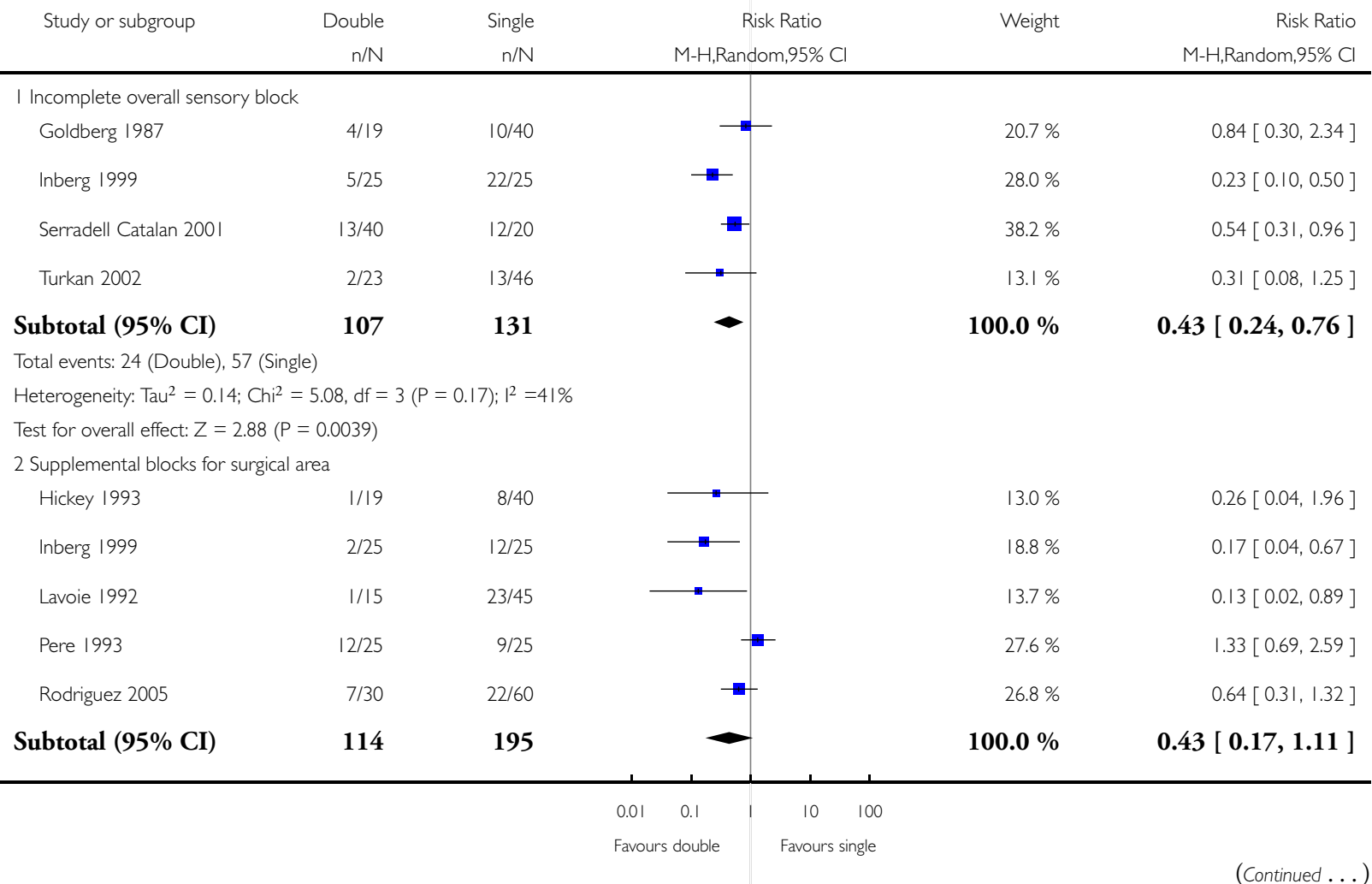




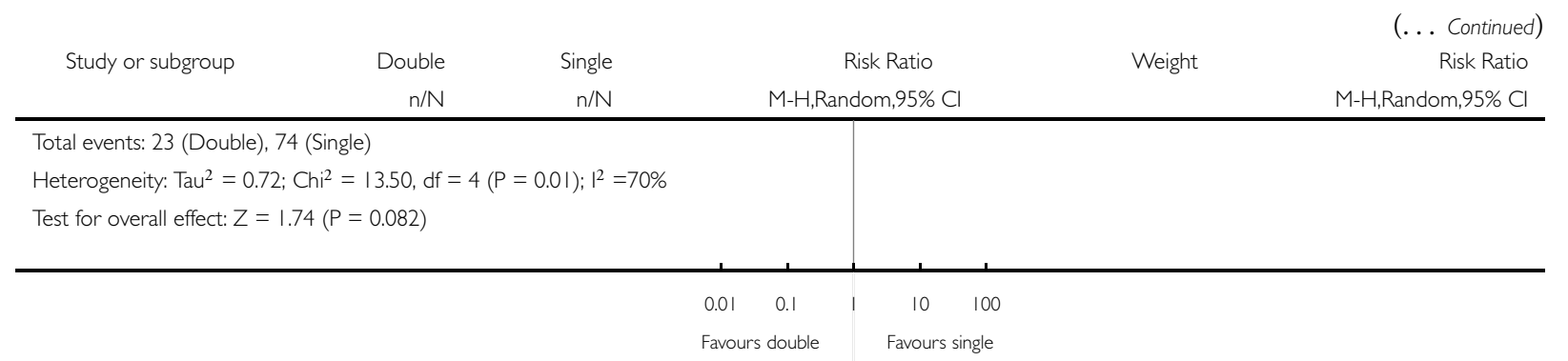

\section{Analysis I.3. Comparison I Double versus single-injection technique, Outcome 3 Complete failure of block: general anaesthesia or new plexus block.}

Review: Single, double or multiple-injection techniques for axillary brachial plexus block for hand, wrist or forearm surgery in adults

Comparison: I Double versus single-injection technique

Outcome: 3 Complete failure of block: general anaesthesia or new plexus block

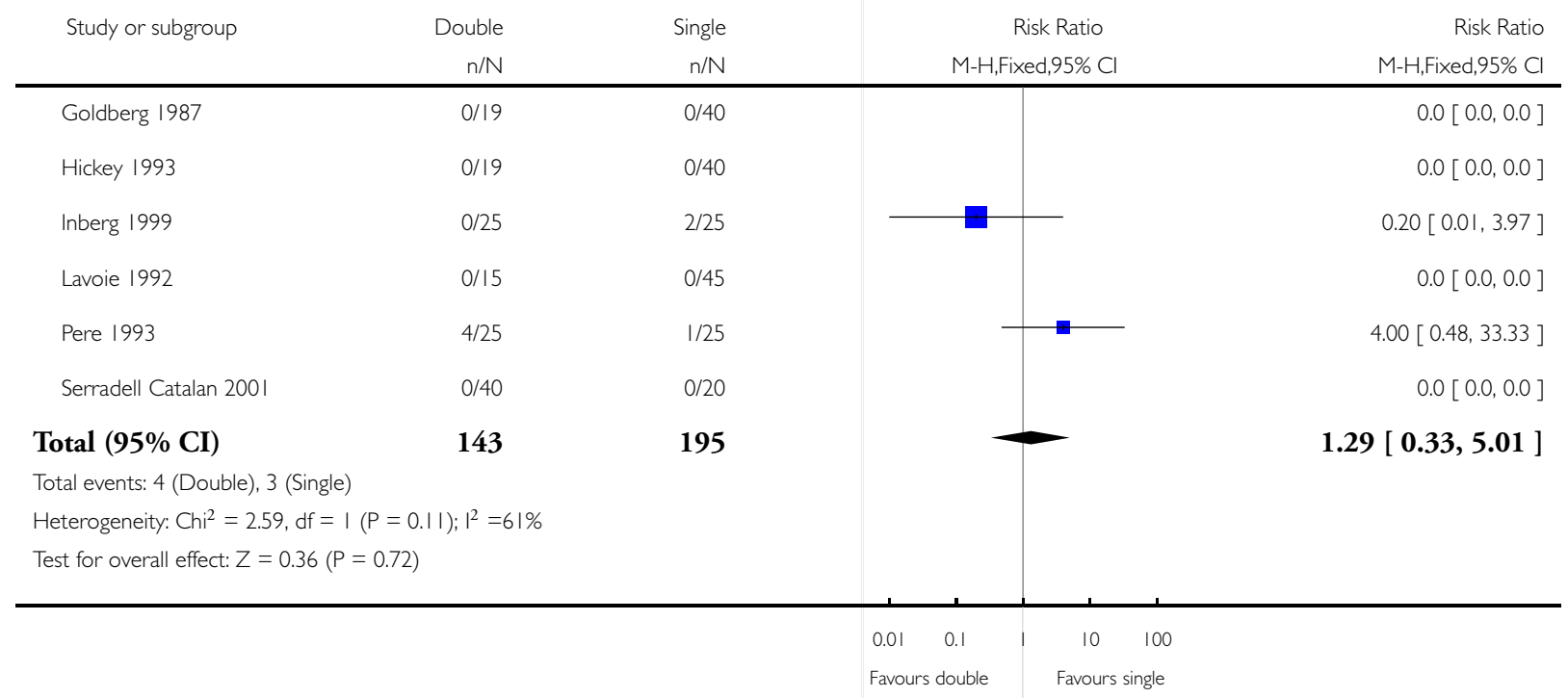


Analysis I.4. Comparison I Double versus single-injection technique, Outcome 4 Incomplete motor block. Review: Single, double or multiple-injection techniques for axillary brachial plexus block for hand, wrist or forearm surgery in adults

Comparison: I Double versus single-injection technique

Outcome: 4 Incomplete motor block

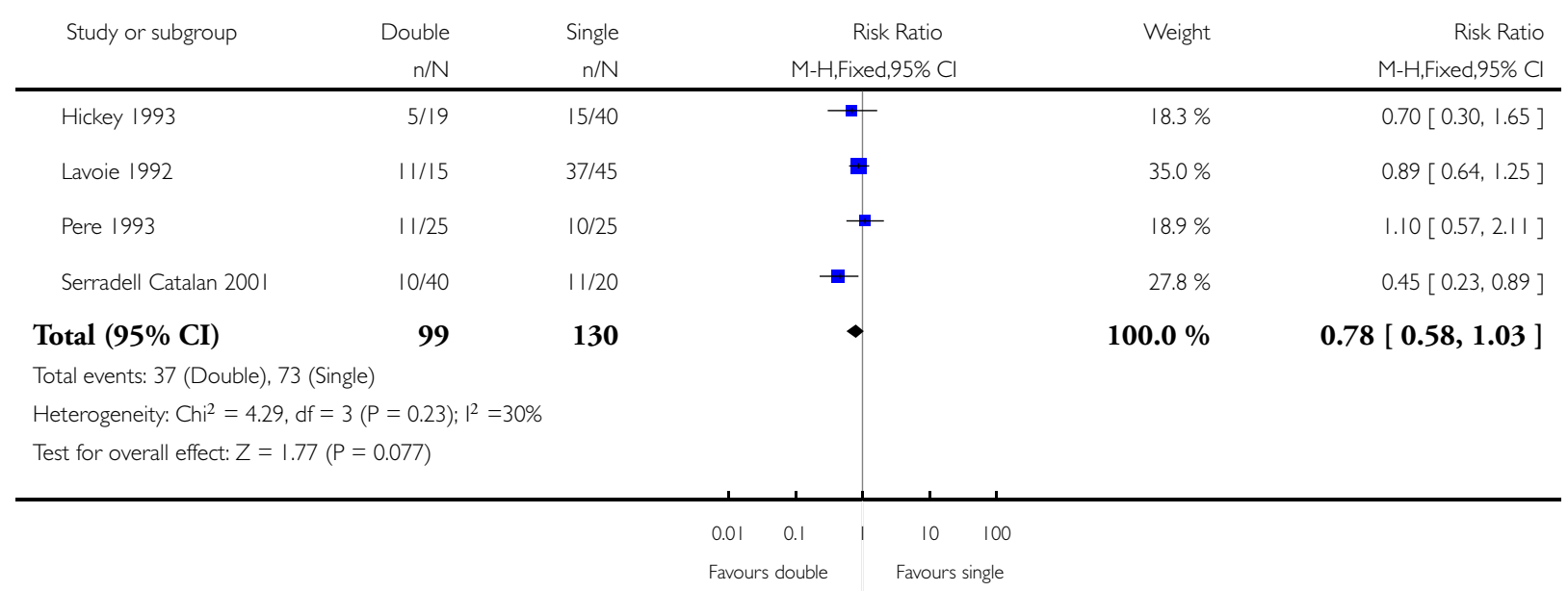


Analysis I.5. Comparison I Double versus single-injection technique, Outcome 5 Secondary analgesia failure.

Review: Single, double or multiple-injection techniques for axillary brachial plexus block for hand, wrist or forearm surgery in adults

Comparison: I Double versus single-injection technique

Outcome: 5 Secondary analgesia failure

Study or subgroup $\quad$ Double $\quad$ Single $\quad$ Risk Ratio Weight

$\mathrm{n} / \mathrm{N} \quad \mathrm{n} / \mathrm{N}$

$\mathrm{n} / \mathrm{N} \quad \mathrm{M}-\mathrm{H}, \mathrm{Fixed}, 95 \% \mathrm{Cl}$

$\mathrm{M}-\mathrm{H}, \mathrm{Fixed}, 95 \% \mathrm{Cl}$

| Pain in surgical site/operative field
Inberg 1999
Pere 1993
Serradell Catalan 200 |

\section{Subtotal (95\% CI)}

$0 / 25 \quad 2 / 25$

25

$6 / 25 \quad 5 / 25$

$1 / 40 \quad 4 / 20$

Total events: 7 (Double), I I (Single)

90

$4 / 20$

Heterogeneity: $\mathrm{Chi}^{2}=4.40, \mathrm{df}=2(\mathrm{P}=0.1 \mathrm{I}) ; \mathrm{I}^{2}=55 \%$

Test for overall effect: $Z=1.41(P=0.16)$

2 Tourniquet pain

70

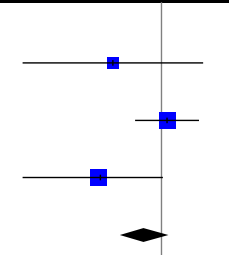

$19.5 \%$

$0.20[0.01,3.97]$

$\begin{array}{lll}\text { Inberg I999 } & 4 / 25 & \text { 8/25 } \\ \text { Serradell Catalan 200 I } & \text { 2/35 }\end{array}$

Subtotal (95\% CI)

60

Total events: 6 (Double), 9 (Single)

Heterogeneity: $\mathrm{Chi}^{2}=0.35, \mathrm{df}=\mathrm{I}(\mathrm{P}=0.55) ; \mathrm{I}^{2}=0.0 \%$

Test for overall effect: $Z=1.1$ I $(P=0.27)$

3 Intra-operative sedatives

Serradell Catalan 200I

Turkan 2002

$6 / 23 \quad 20 / 46$

$8 / 25$

$1 / 19$

44

Subtotal (95\% CI)

63

Total events: 8 (Double), 2 I (Single)

Heterogeneity: $\mathrm{Chi}^{2}=0.17, \mathrm{df}=\mathrm{I}(\mathrm{P}=0.68) ; \mathrm{I}^{2}=0.0 \%$

Test for overall effect: $Z=1.22(P=0.22)$
66
$9.1 \%$

$90.9 \%$

$100.0 \%$
$1.20[0.42,3.43]$

$0.13[0.01,1.05]$

$100.0 \%$

$0.56[0.25,1.25]$

$86.1 \%$

$0.50[0.17,1.45]$

$13.9 \%$

$1.09[0.11,11.21]$

$100.0 \%$

$0.58[0.22,1.52]$
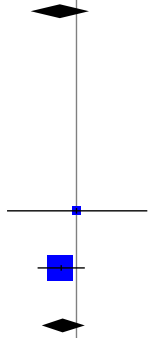

$-$
$.00[0.10,10.38]$

$0.60[0.28,1.29]$

$0.64[0.31,1.31]$ 
Analysis 1.6. Comparison I Double versus single-injection technique, Outcome 6 Timing (in minutes).

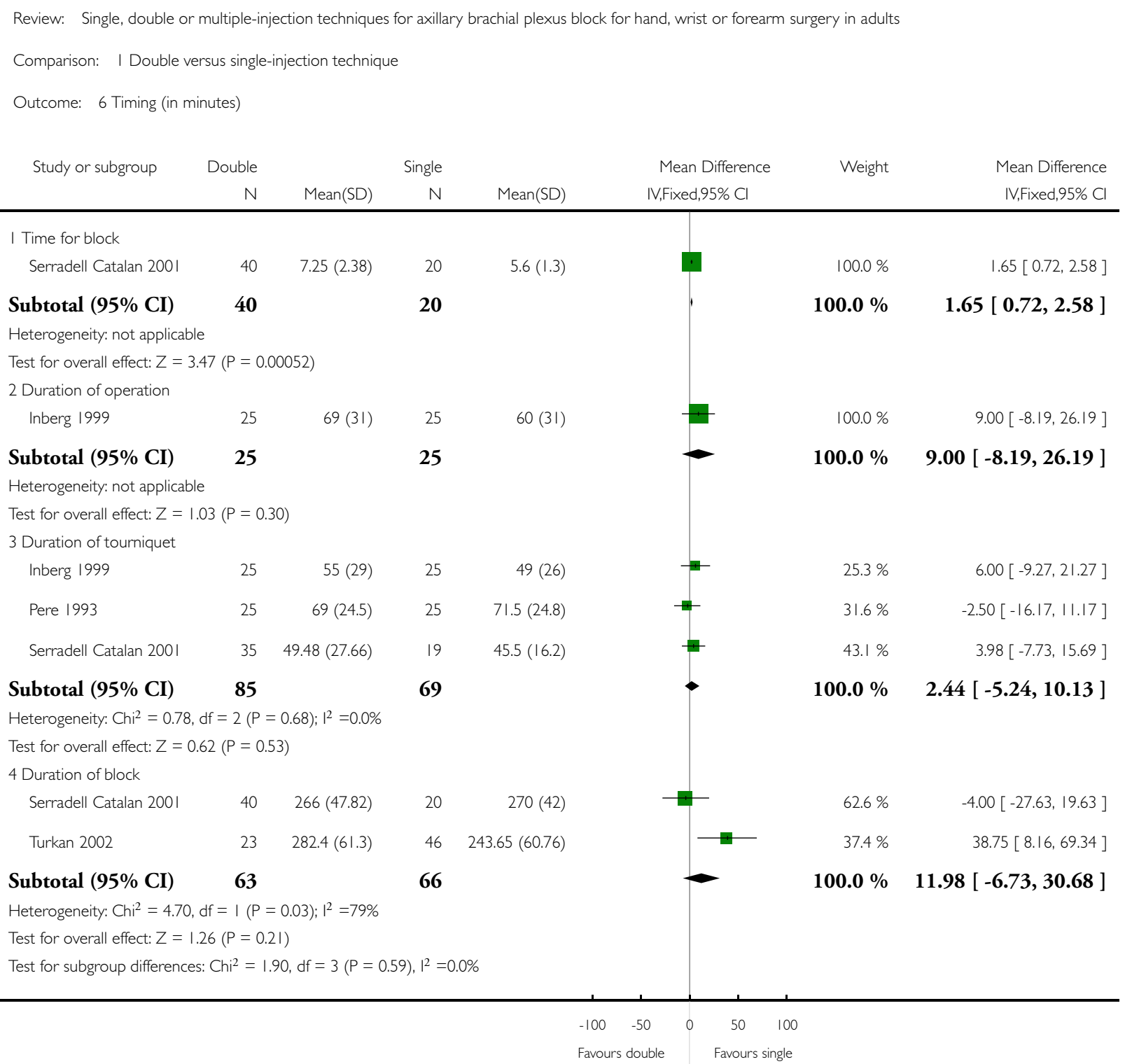




\section{Analysis I.7. Comparison I Double versus single-injection technique, Outcome 7 Complications during}

nerve block.

Review: Single, double or multiple-injection techniques for axillary brachial plexus block for hand, wrist or forearm surgery in adults

Comparison: I Double versus single-injection technique

Outcome: 7 Complications during nerve block

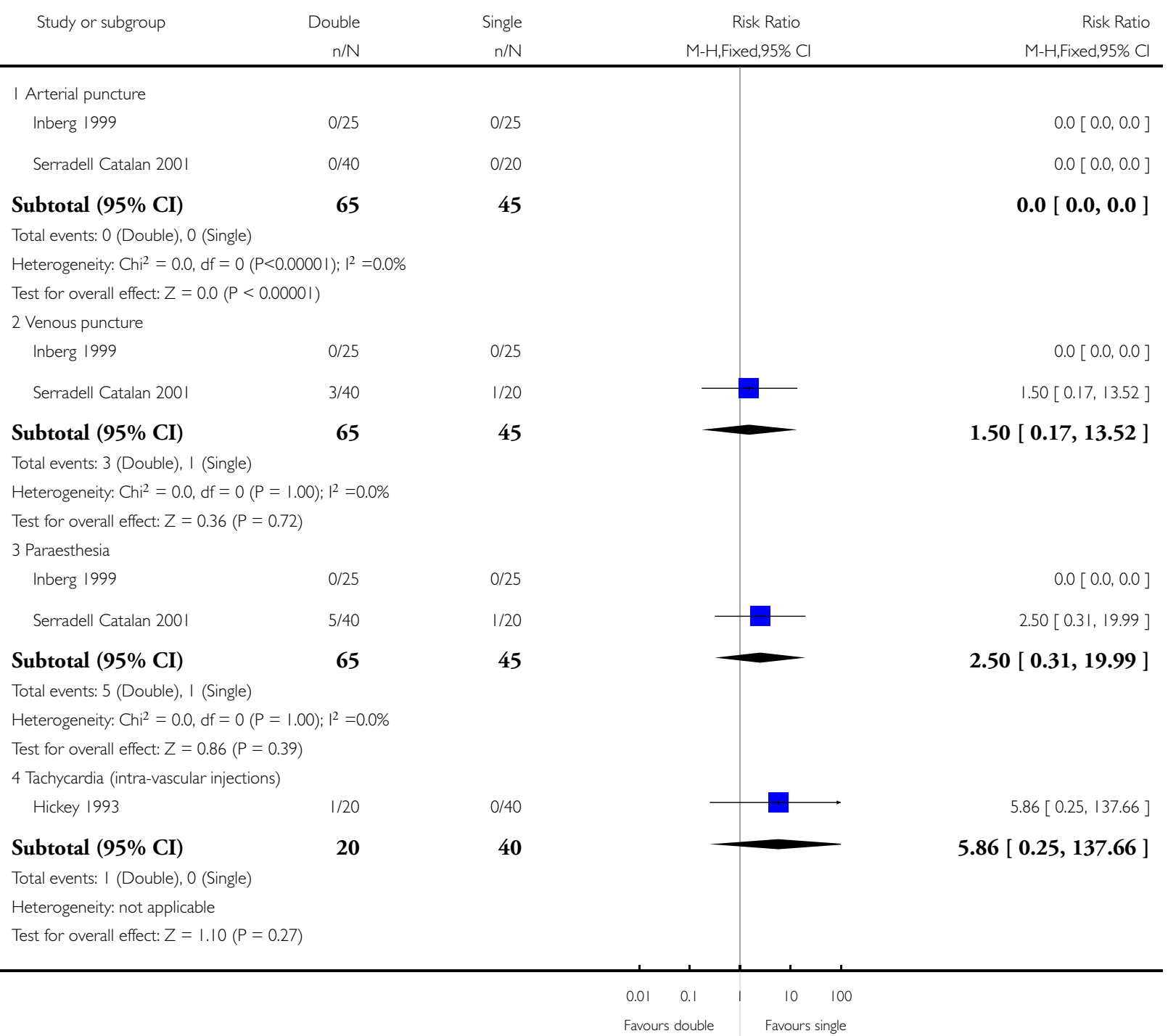


Analysis I.8. Comparison I Double versus single-injection technique, Outcome 8 Adverse effects (> 24 hours).

Review: Single, double or multiple-injection techniques for axillary brachial plexus block for hand, wrist or forearm surgery in adults

Comparison: I Double versus single-injection technique

Outcome: 8 Adverse effects (> 24 hours)

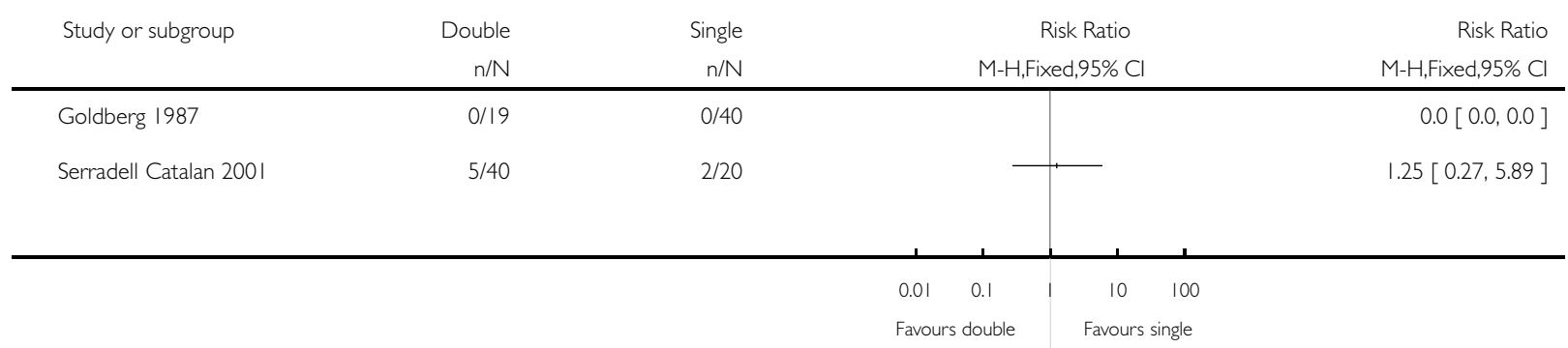

Analysis I.9. Comparison I Double versus single-injection technique, Outcome 9 Patient discomfort and dissatisfaction with method.

Review: Single, double or multiple-injection techniques for axillary brachial plexus block for hand, wrist or forearm surgery in adults

Comparison: I Double versus single-injection technique

Outcome: 9 Patient discomfort and dissatisfaction with method

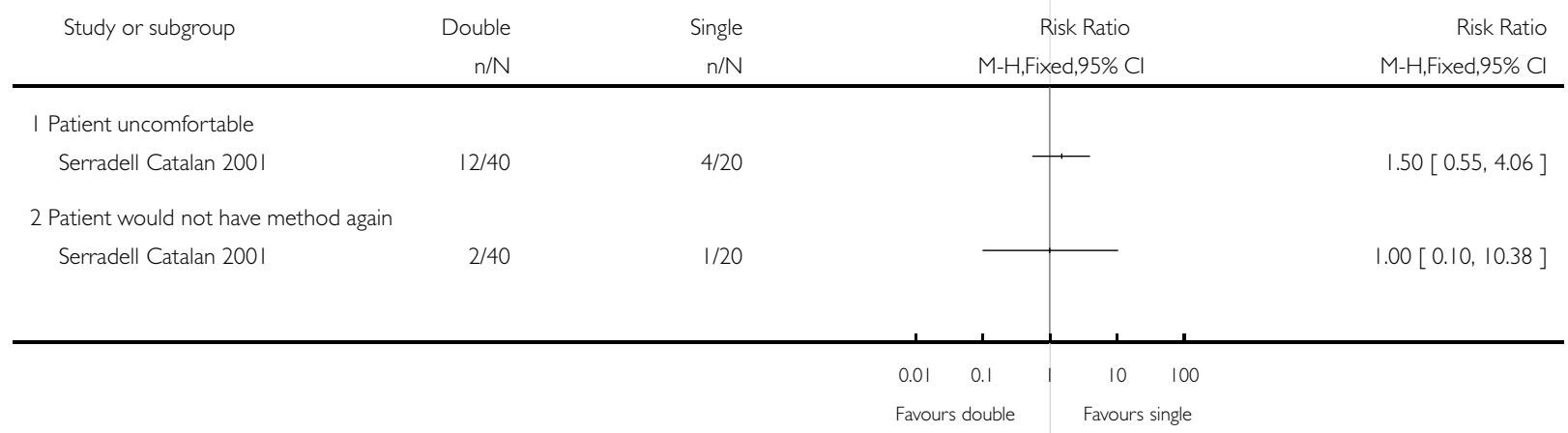


Analysis 2.I. Comparison 2 Multiple versus single-injection technique, Outcome I Primary anaesthesia failure (incomplete sensory block).

Review: Single, double or multiple-injection techniques for axillary brachial plexus block for hand, wrist or forearm surgery in adults

Comparison: 2 Multiple versus single-injection technique

Outcome: I Primary anaesthesia failure (incomplete sensory block)

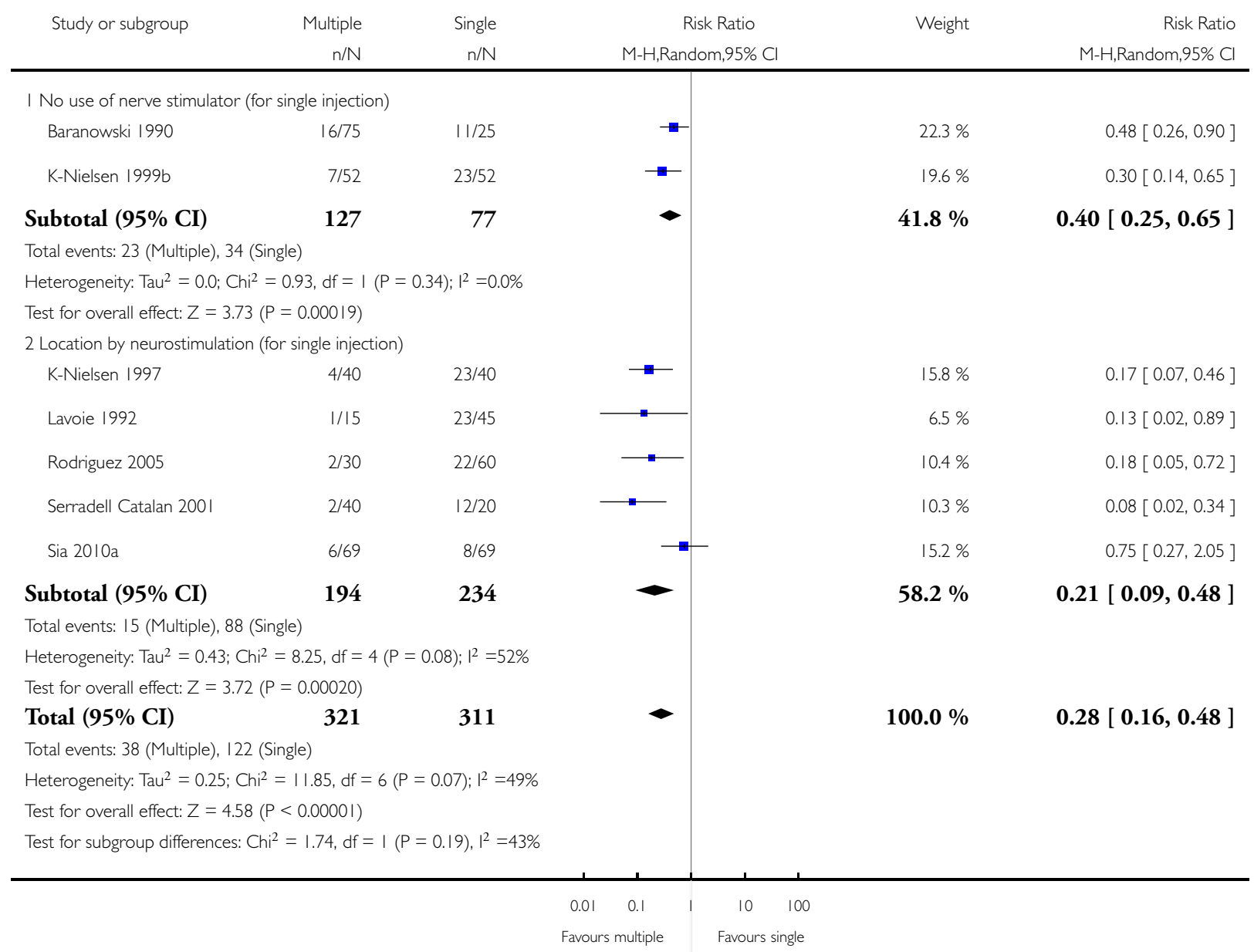


Analysis 2.2. Comparison 2 Multiple versus single-injection technique, Outcome 2 Primary anaesthesia failure - subgrouped by outcome definition.

Review: Single, double or multiple-injection techniques for axillary brachial plexus block for hand, wrist or forearm surgery in adults

Comparison: 2 Multiple versus single-injection technique

Outcome: 2 Primary anaesthesia failure - subgrouped by outcome definition

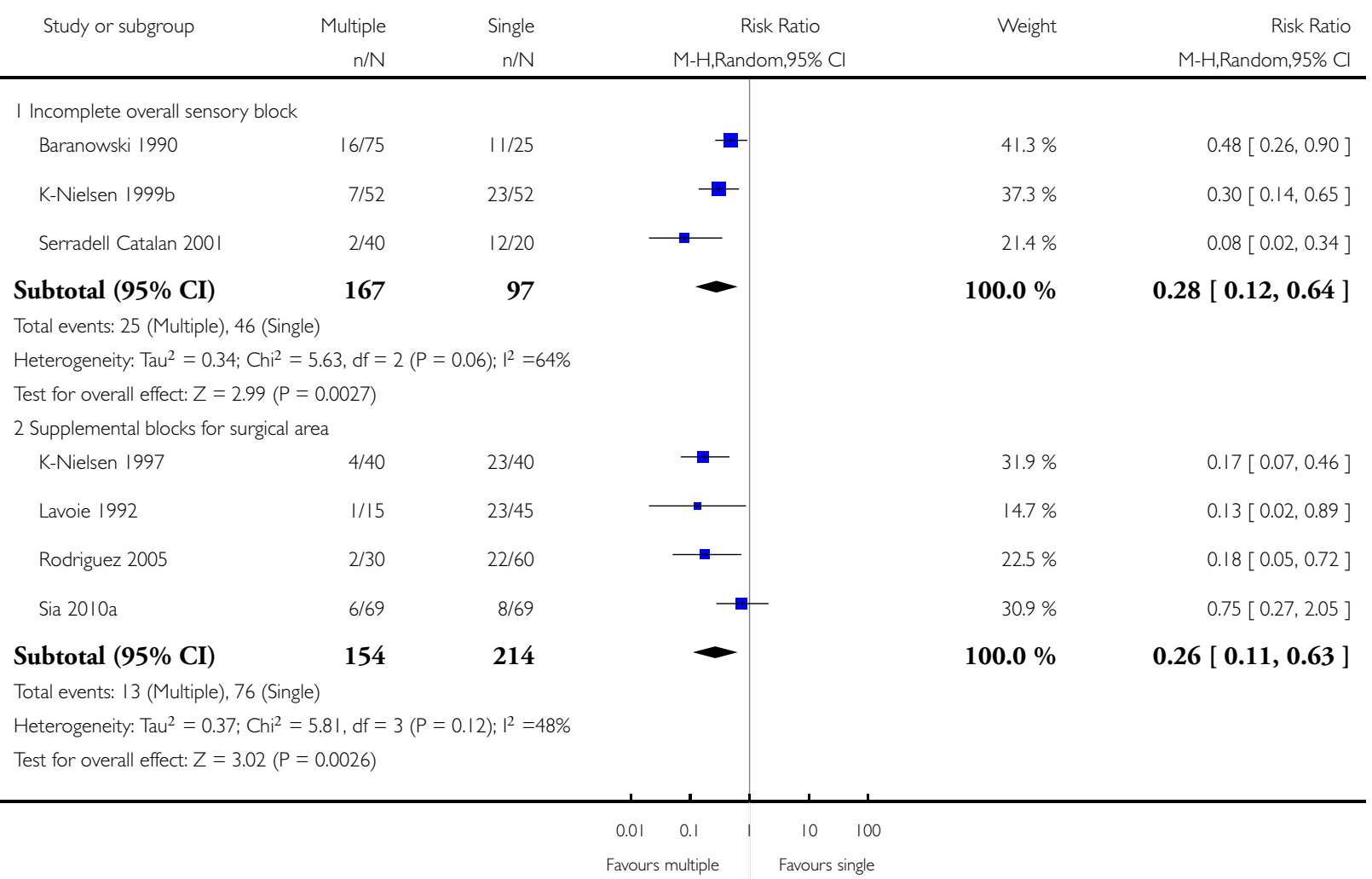


Analysis 2.3. Comparison 2 Multiple versus single-injection technique, Outcome 3 Complete failure of block: general anaesthesia or new plexus block.

Review: Single, double or multiple-injection techniques for axillary brachial plexus block for hand, wrist or forearm surgery in adults

Comparison: 2 Multiple versus single-injection technique

Outcome: 3 Complete failure of block: general anaesthesia or new plexus block

\begin{tabular}{|c|c|c|c|c|}
\hline \multirow[t]{2}{*}{ Study or subgroup } & Multiple & Single & Risk Ratio & Risk Ratio \\
\hline & $\mathrm{n} / \mathrm{N}$ & $\mathrm{n} / \mathrm{N}$ & M-H,Random,95\% Cl & M-H,Random,95\% Cl \\
\hline Baranowski 1990 & $0 / 75$ & $2 / 25$ & + & $0.07[0.00,1.38]$ \\
\hline K-Nielsen 1997 & $1 / 40$ & $0 / 40$ & & $3.00[0.13,71.51]$ \\
\hline K-Nielsen 1999b & $0 / 52$ & $0 / 52$ & & $0.0[0.0,0.0]$ \\
\hline Lavoie 1992 & $0 / 15$ & $0 / 45$ & & $0.0[0.0,0.0]$ \\
\hline Serradell Catalan 200I & $0 / 40$ & $0 / 20$ & & $0.0[0.0,0.0]$ \\
\hline Total (95\% CI) & 222 & 182 & & $0.44[0.01,17.76]$ \\
\hline \multicolumn{5}{|c|}{ Total events: I (Multiple), 2 (Single) } \\
\hline \multicolumn{5}{|c|}{ Heterogeneity: $\operatorname{Tau}^{2}=4.66 ; \mathrm{Chi}^{2}=2.88, \mathrm{df}=\mathrm{I}(\mathrm{P}=0.09) ; \mathrm{I}^{2}=65 \%$} \\
\hline \multicolumn{5}{|c|}{ Test for overall effect: $Z=0.44(P=0.66)$} \\
\hline
\end{tabular}

$0.0010 .01 \quad 0.1 \quad 1 \quad 10 \quad 100 \quad 1000$

Favours multiple Favours single

Analysis 2.4. Comparison 2 Multiple versus single-injection technique, Outcome 4 Incomplete motor block.

Review: Single, double or multiple-injection techniques for axillary brachial plexus block for hand, wrist or forearm surgery in adults

Comparison: 2 Multiple versus single-injection technique

Outcome: 4 Incomplete motor block

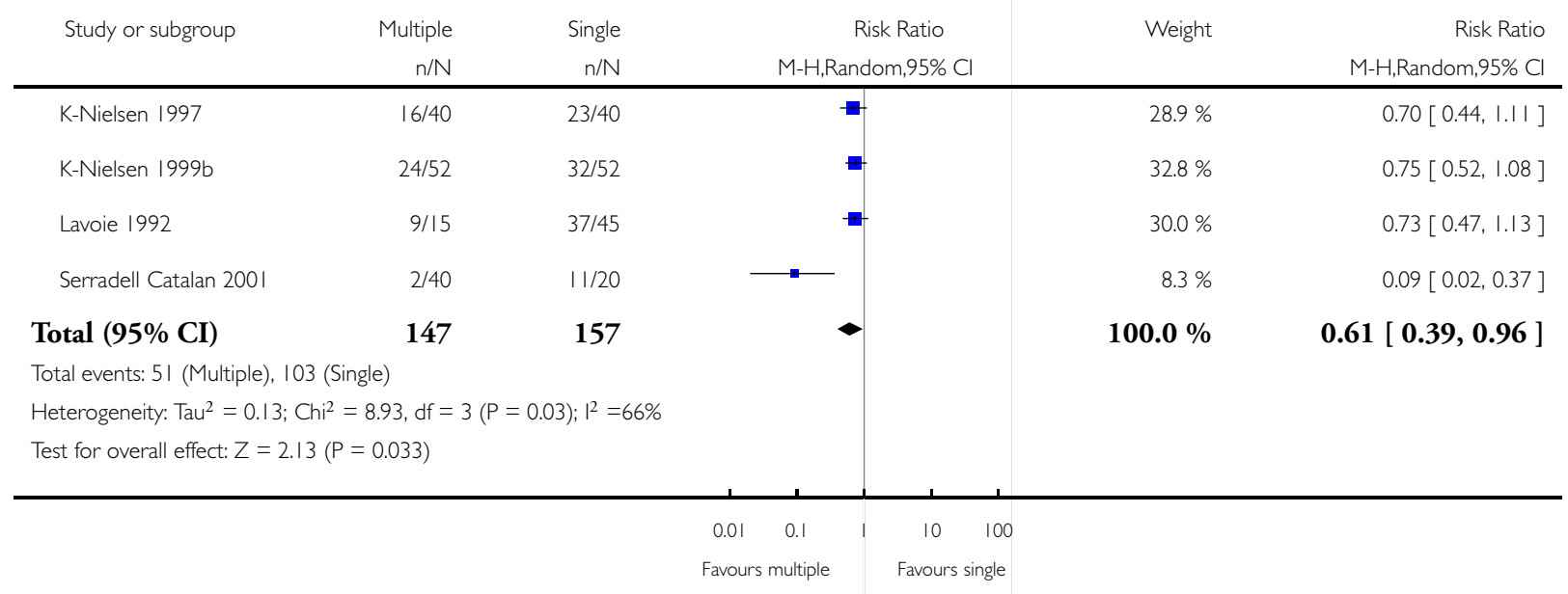

Single, double or multiple-injection techniques for axillary brachial plexus block for hand, wrist or forearm surgery in adults (Review) 
Analysis 2.5. Comparison 2 Multiple versus single-injection technique, Outcome 5 Secondary analgesia failure.

Review: Single, double or multiple-injection techniques for axillary brachial plexus block for hand, wrist or forearm surgery in adults

Comparison: 2 Multiple versus single-injection technique

Outcome: 5 Secondary analgesia failure

$\begin{array}{llll}\text { Study or subgroup } & \text { Multiple } & \text { Ringle } & \text { Risk Ratio Ratio }\end{array}$

$\mathrm{n} / \mathrm{N} \quad \mathrm{n} / \mathrm{N} \quad \mathrm{M}-\mathrm{H}$, Random, $95 \% \mathrm{Cl}$

M-H,Random,95\% C

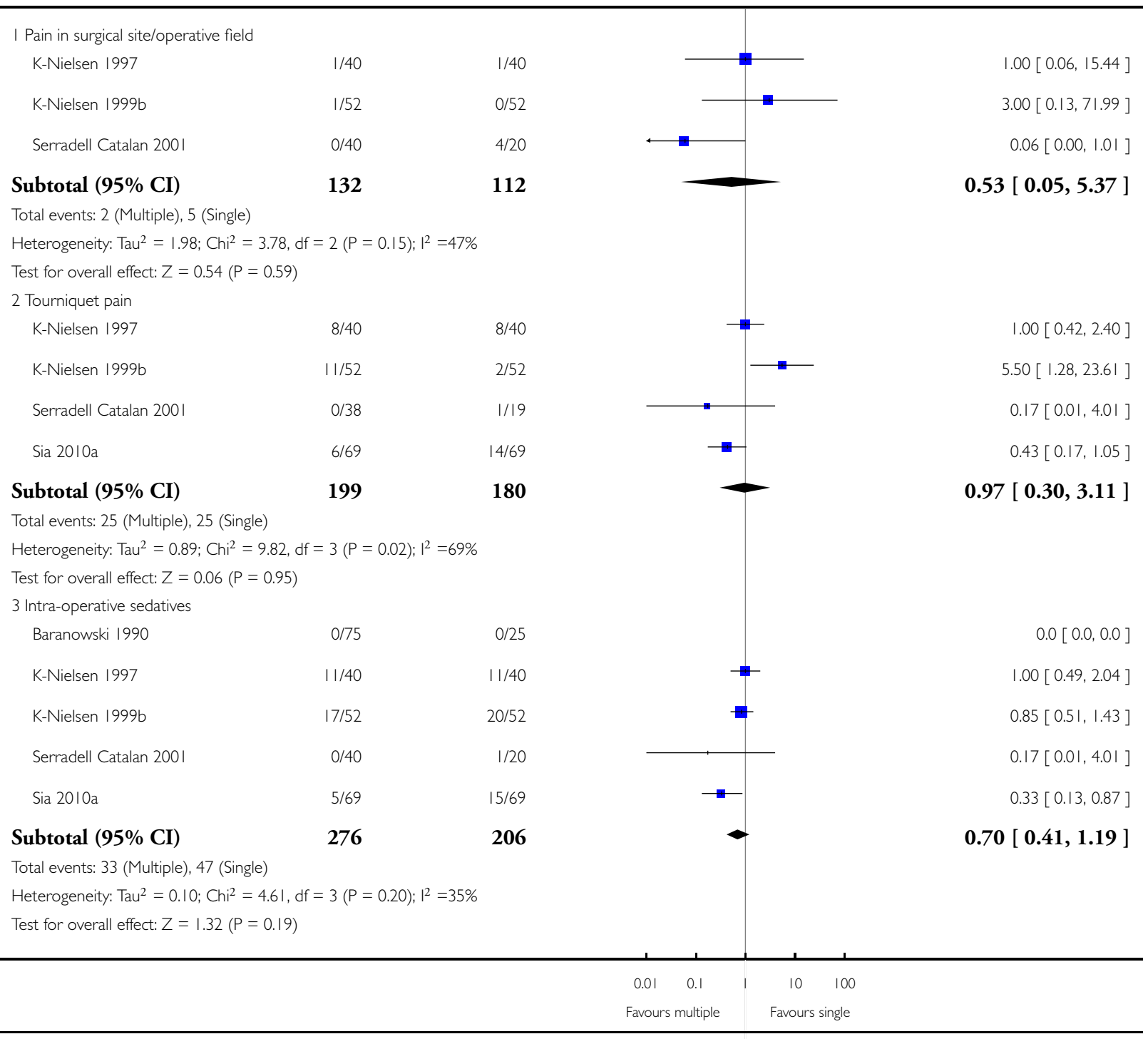

Single, double or multiple-injection techniques for axillary brachial plexus block for hand, wrist or forearm surgery in adults (Review) 
Analysis 2.6. Comparison 2 Multiple versus single-injection technique, Outcome 6 Timing (in minutes).

Review: Single, double or multiple-injection techniques for axillary brachial plexus block for hand, wrist or forearm surgery in adults

Comparison: 2 Multiple versus single-injection technique

Outcome: 6 Timing (in minutes)

\begin{tabular}{|c|c|c|c|c|c|c|c|c|c|}
\hline \multirow[t]{2}{*}{ Study or subgroup } & \multirow{2}{*}{$\begin{array}{r}\text { Multiple } \\
\mathrm{N}\end{array}$} & \multicolumn{3}{|c|}{ Single } & \multicolumn{3}{|c|}{ Mean Difference } & \multirow[t]{2}{*}{ Weight } & \multirow{2}{*}{$\begin{array}{l}\text { Mean Difference } \\
\text { IV,Random,95\% Cl }\end{array}$} \\
\hline & & Mean(SD) & N & Mean(SD) & & IV,Ranc & $\mathrm{lom}, 95 \% \mathrm{Cl}$ & & \\
\hline \multicolumn{10}{|l|}{ I Time for block } \\
\hline K-Nielsen 1997 & 40 & $9.5(2.2)$ & 40 & $5.5(0.9)$ & & & 1 & $34.5 \%$ & $4.00[3.26,4.74]$ \\
\hline Serradell Catalan 200I & 40 & $8.6(2.7)$ & 20 & $5.6(1.3)$ & & & \pm & $25.4 \%$ & $3.00[1.99,4.01]$ \\
\hline Sia $2010 a$ & 69 & $7.1(2.1)$ & 69 & $4.1(1.4)$ & & & 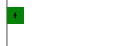 & $40.1 \%$ & $3.00[2.40,3.60]$ \\
\hline Subtotal $(95 \%$ CI) & 149 & & 129 & & & & 1 & $100.0 \%$ & $3.34[2.66,4.03]$ \\
\hline \multicolumn{10}{|c|}{ Heterogeneity: $\operatorname{Tau}^{2}=0.21 ; \mathrm{Chi}^{2}=4.77, \mathrm{df}=2(\mathrm{P}=0.09) ; \mathrm{I}^{2}=58 \%$} \\
\hline \multicolumn{10}{|c|}{ Test for overall effect: $Z=9.63(P<0.0000 I)$} \\
\hline \multicolumn{10}{|c|}{2 Time for readiness for surgery } \\
\hline K-Nielsen 1997 & 40 & $25(6)$ & 40 & $38.5(7)$ & & + & & $49.9 \%$ & $-13.50[-16.36,-10.64]$ \\
\hline Sia 2010a & 63 & $21.1(7)$ & 63 & $14.3(6.6)$ & & & + & $50.1 \%$ & $6.80[4.42,9.18]$ \\
\hline Subtotal (95\% CI) & 103 & & 103 & & & & & $100.0 \%$ & $-3.33[-23.23,16.56]$ \\
\hline \multicolumn{10}{|c|}{ Heterogeneity: $\operatorname{Tau}^{2}=204.25 ; \mathrm{Chi}^{2}=||$ 14.65, df $=|(P<0.0000 \mathrm{I}) ;|^{2}=99 \%$} \\
\hline \multicolumn{10}{|c|}{ Test for overall effect: $Z=0.33(P=0.74)$} \\
\hline \multicolumn{10}{|l|}{3 Duration of tourniquet } \\
\hline K-Nielsen 1997 & 40 & $73(30)$ & 40 & $73(31)$ & & & 一 & $11.4 \%$ & $0.0[-13.37,13.37]$ \\
\hline K-Nielsen 1999b & 52 & $65(25)$ & 52 & $65(28)$ & & & - & $19.6 \%$ & $0.0[-10.20,10.20]$ \\
\hline Serradell Catalan 200I & 38 & $52.6(55.33)$ & 19 & $45.5(16.2)$ & & & $\mp$ & $5.6 \%$ & $7.10[-11.94,26.14]$ \\
\hline Sia $2010 a$ & 69 & $45(16)$ & 69 & $42(18)$ & & & † & $63.3 \%$ & $3.00[-2.68,8.68]$ \\
\hline Subtotal (95\% CI) & 199 & & 180 & & & & 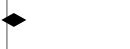 & $100.0 \%$ & $2.30[-2.22,6.82]$ \\
\hline \multicolumn{10}{|c|}{ Heterogeneity: $\operatorname{Tau}^{2}=0.0 ; \mathrm{Chi}^{2}=0.6 \mathrm{I}, \mathrm{df}=3(\mathrm{P}=0.89) ; \mathrm{I}^{2}=0.0 \%$} \\
\hline \multicolumn{10}{|c|}{ Test for overall effect: $Z=1.00(P=0.32)$} \\
\hline \multicolumn{10}{|l|}{4 Duration of block } \\
\hline Serradell Catalan 2001 & 40 & $250.5(55.16)$ & 20 & $270(42)$ & & & - & $100.0 \%$ & $-19.50[-44.62,5.62]$ \\
\hline Subtotal (95\% CI) & 40 & & 20 & & & & & $100.0 \%$ & $-19.50[-44.62,5.62]$ \\
\hline \multicolumn{10}{|l|}{ Heterogeneity: not applicable } \\
\hline \multicolumn{10}{|c|}{ Test for overall effect: $Z=1.52(P=0.13)$} \\
\hline \multicolumn{10}{|l|}{5 Length of surgery } \\
\hline Sia 2010a & 69 & $52(18)$ & 69 & $50(15)$ & & & & $100.0 \%$ & $2.00[-3.53,7.53]$ \\
\hline Subtotal $(95 \%$ CI) & 69 & & 69 & & & & 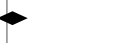 & $100.0 \%$ & $2.00[-3.53,7.53]$ \\
\hline \multicolumn{10}{|l|}{ Heterogeneity: not applicable } \\
\hline \multicolumn{10}{|c|}{ Test for overall effect: $Z=0.71(P=0.48)$} \\
\hline & & & & & -50 & -25 & 25 & 50 & \\
\hline & & & & & Favours & nultiple & Favours sin & & \\
\hline
\end{tabular}

Single, double or multiple-injection techniques for axillary brachial plexus block for hand, wrist or forearm surgery in adults (Review) 


\section{Analysis 2.7. Comparison 2 Multiple versus single-injection technique, Outcome 7 Complications during} nerve block.

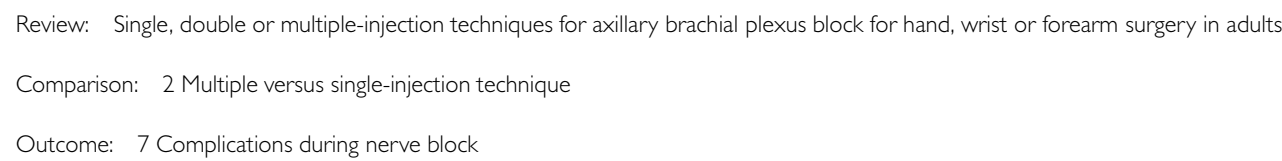

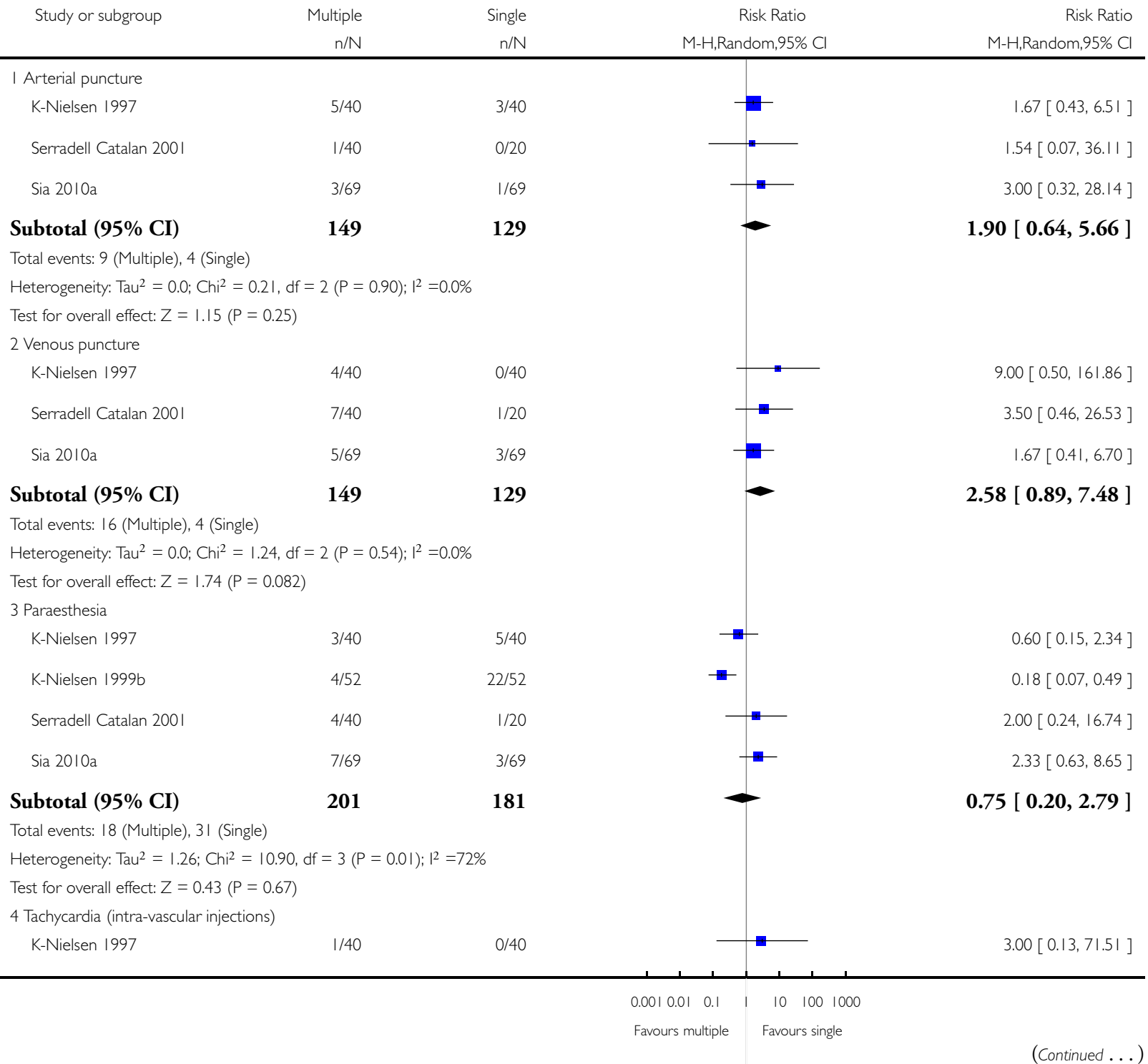




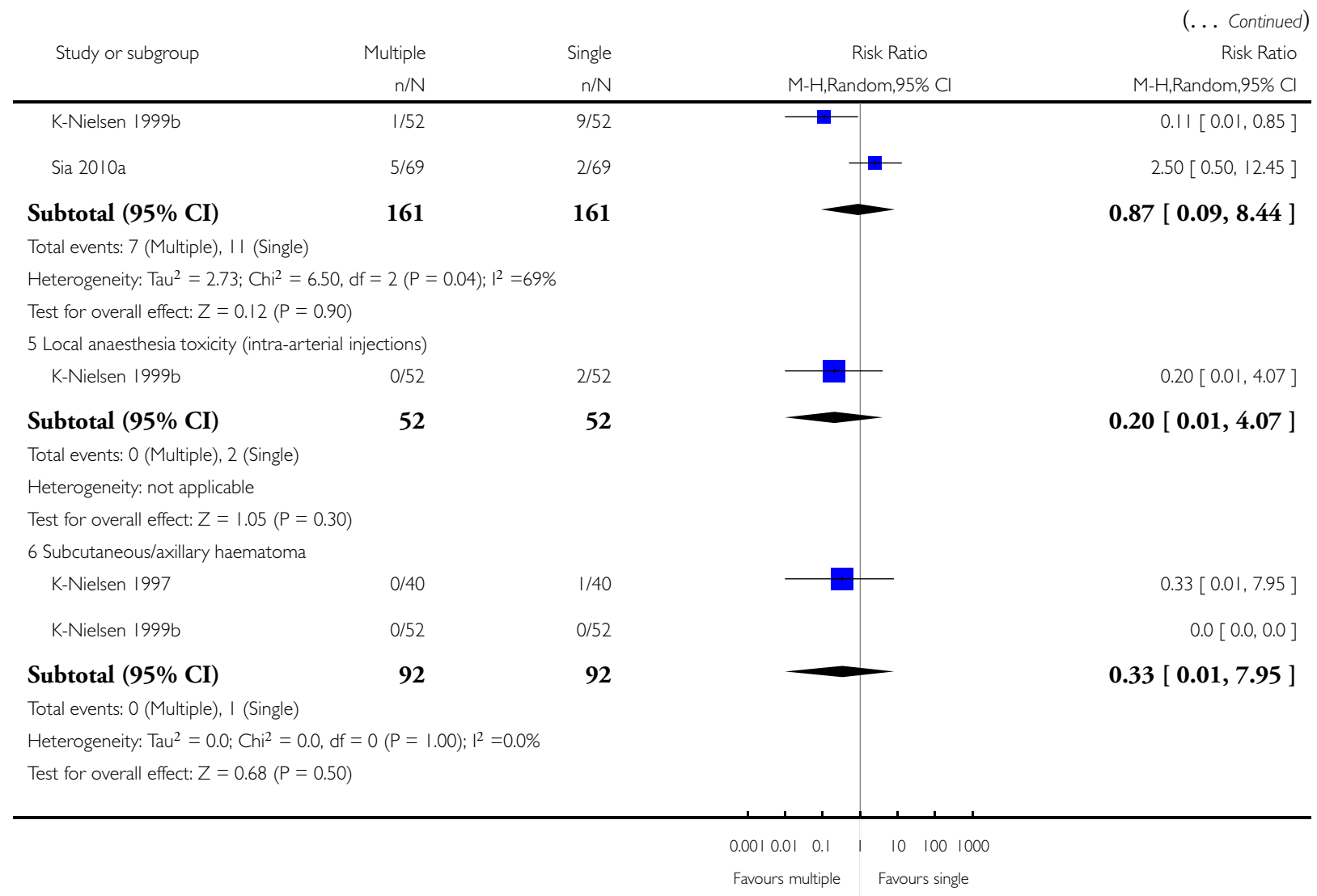

Analysis 2.8. Comparison 2 Multiple versus single-injection technique, Outcome 8 Adverse effects $>24$ hours.

Review: Single, double or multiple-injection techniques for axillary brachial plexus block for hand, wrist or forearm surgery in adults

Comparison: 2 Multiple versus single-injection technique

Outcome: 8 Adverse effects $>24$ hours

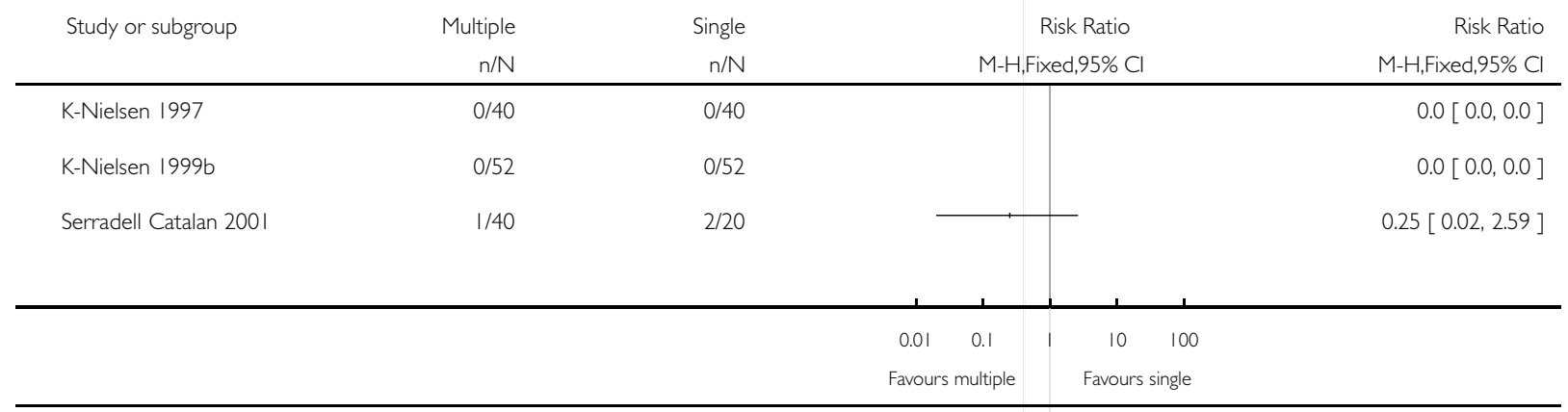


Analysis 2.9. Comparison 2 Multiple versus single-injection technique, Outcome 9 Patient discomfort and dissatisfaction with method.

Review: Single, double or multiple-injection techniques for axillary brachial plexus block for hand, wrist or forearm surgery in adults

Comparison: 2 Multiple versus single-injection technique

Outcome: 9 Patient discomfort and dissatisfaction with method

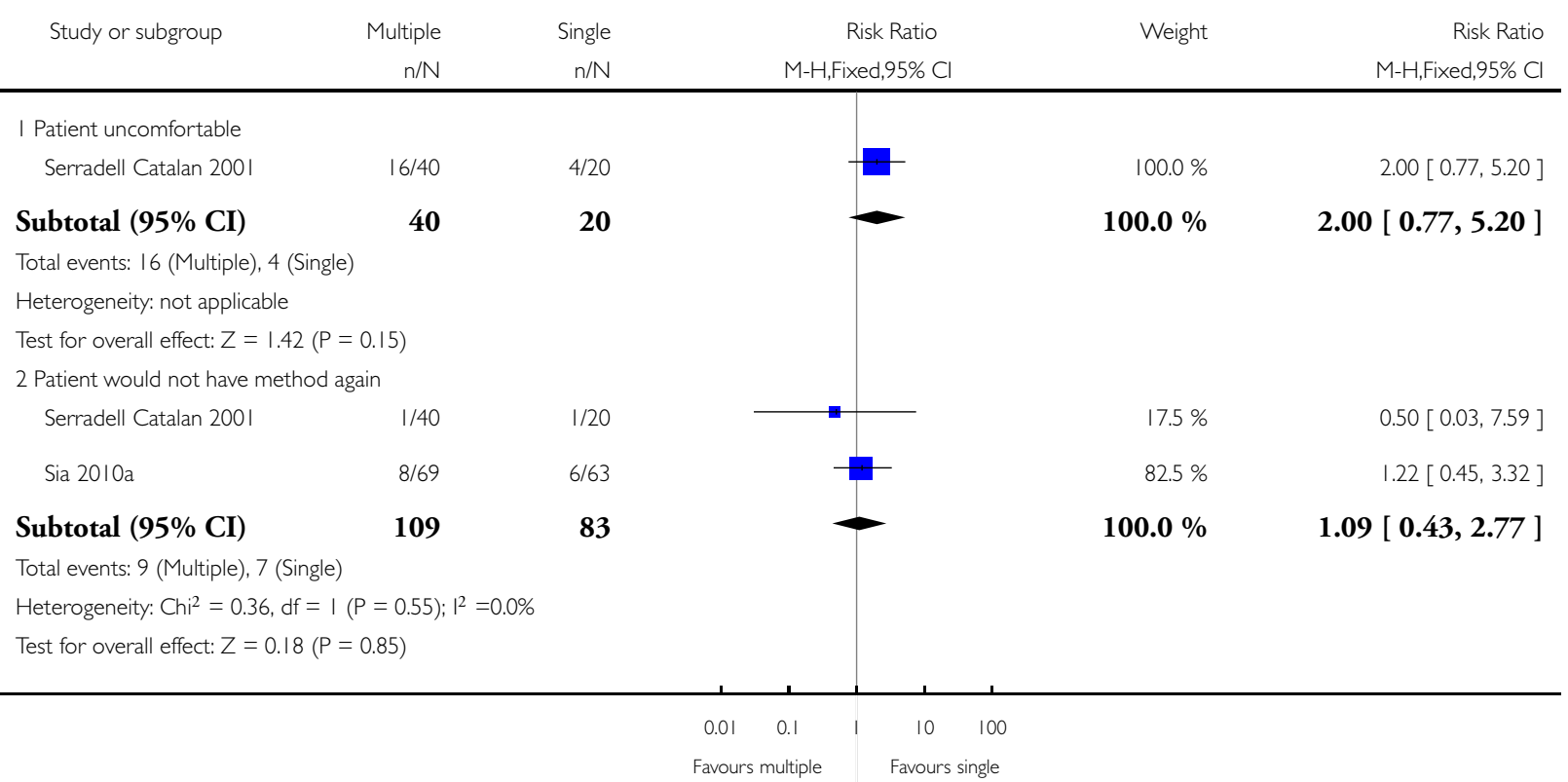


Analysis 3.I. Comparison 3 Multiple versus double-injection technique, Outcome I Primary anaesthesia failure (incomplete sensory block).

Review: Single, double or multiple-injection techniques for axillary brachial plexus block for hand, wrist or forearm surgery in adults

Comparison: 3 Multiple versus double-injection technique

Outcome: I Primary anaesthesia failure (incomplete sensory block)

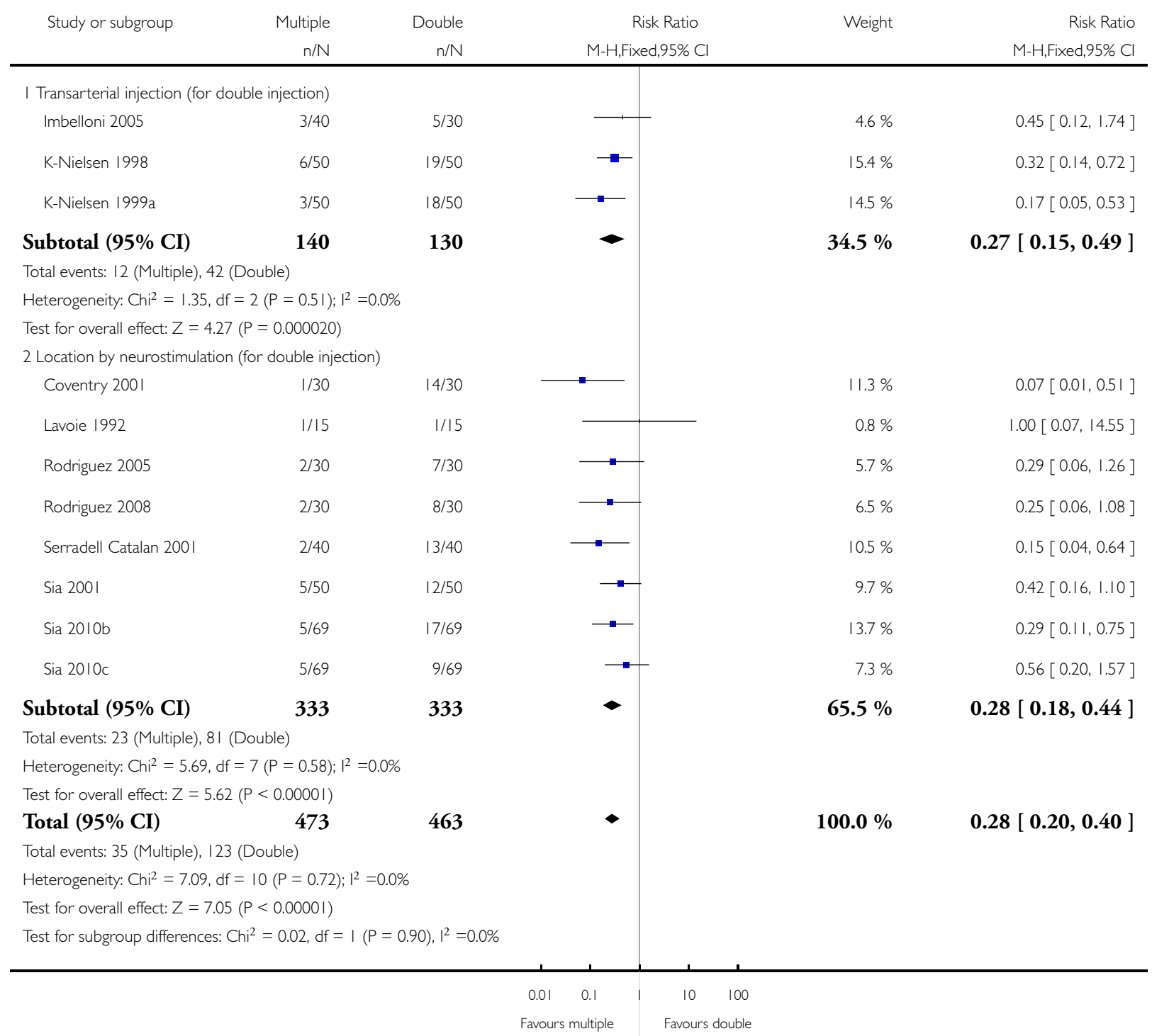


Analysis 3.2. Comparison 3 Multiple versus double-injection technique, Outcome 2 Primary anaesthesia failure - subgrouped by outcome definition.

Review: Single, double or multiple-injection techniques for axillary brachial plexus block for hand, wrist or forearm surgery in adults

Comparison: 3 Multiple versus double-injection technique

Outcome: 2 Primary anaesthesia failure - subgrouped by outcome definition

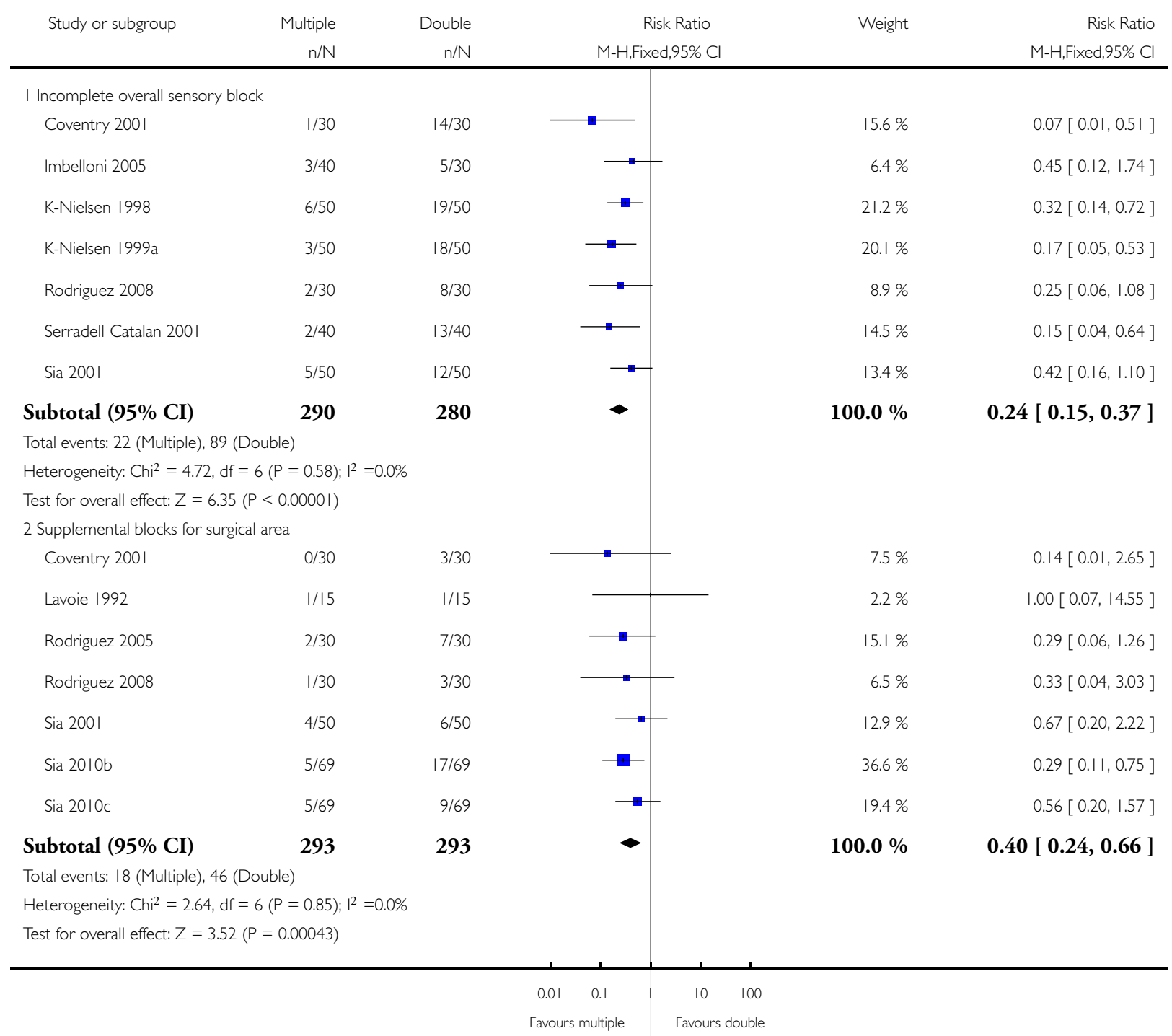




\section{Analysis 3.3. Comparison 3 Multiple versus double-injection technique, Outcome 3 Complete failure of}

block: general anaesthesia or new plexus block.

Review: Single, double or multiple-injection techniques for axillary brachial plexus block for hand, wrist or forearm surgery in adults

Comparison: 3 Multiple versus double-injection technique

Outcome: 3 Complete failure of block: general anaesthesia or new plexus block

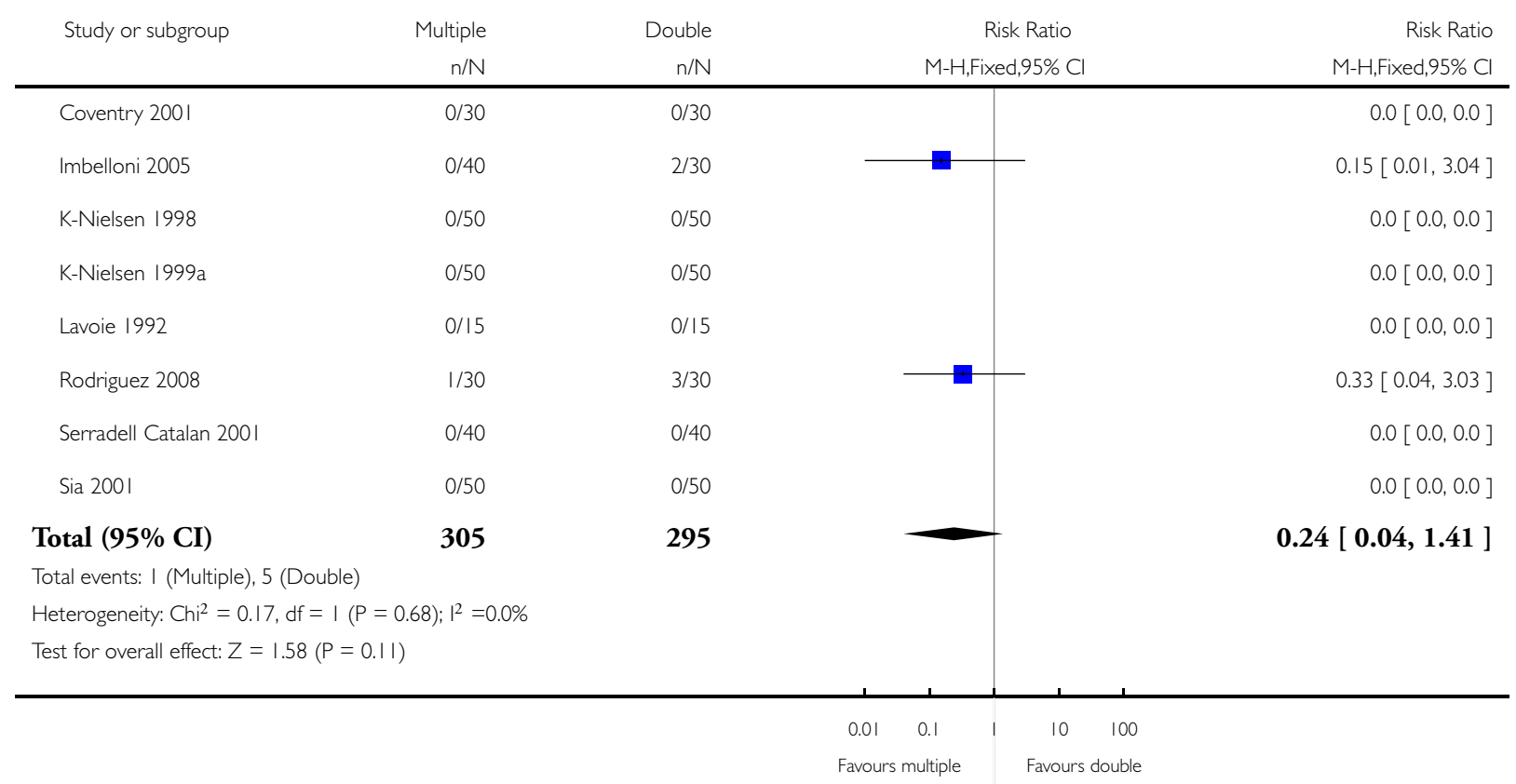


Analysis 3.4. Comparison 3 Multiple versus double-injection technique, Outcome 4 Incomplete motor block.

Review: Single, double or multiple-injection techniques for axillary brachial plexus block for hand, wrist or forearm surgery in adults

Comparison: 3 Multiple versus double-injection technique

Outcome: 4 Incomplete motor block

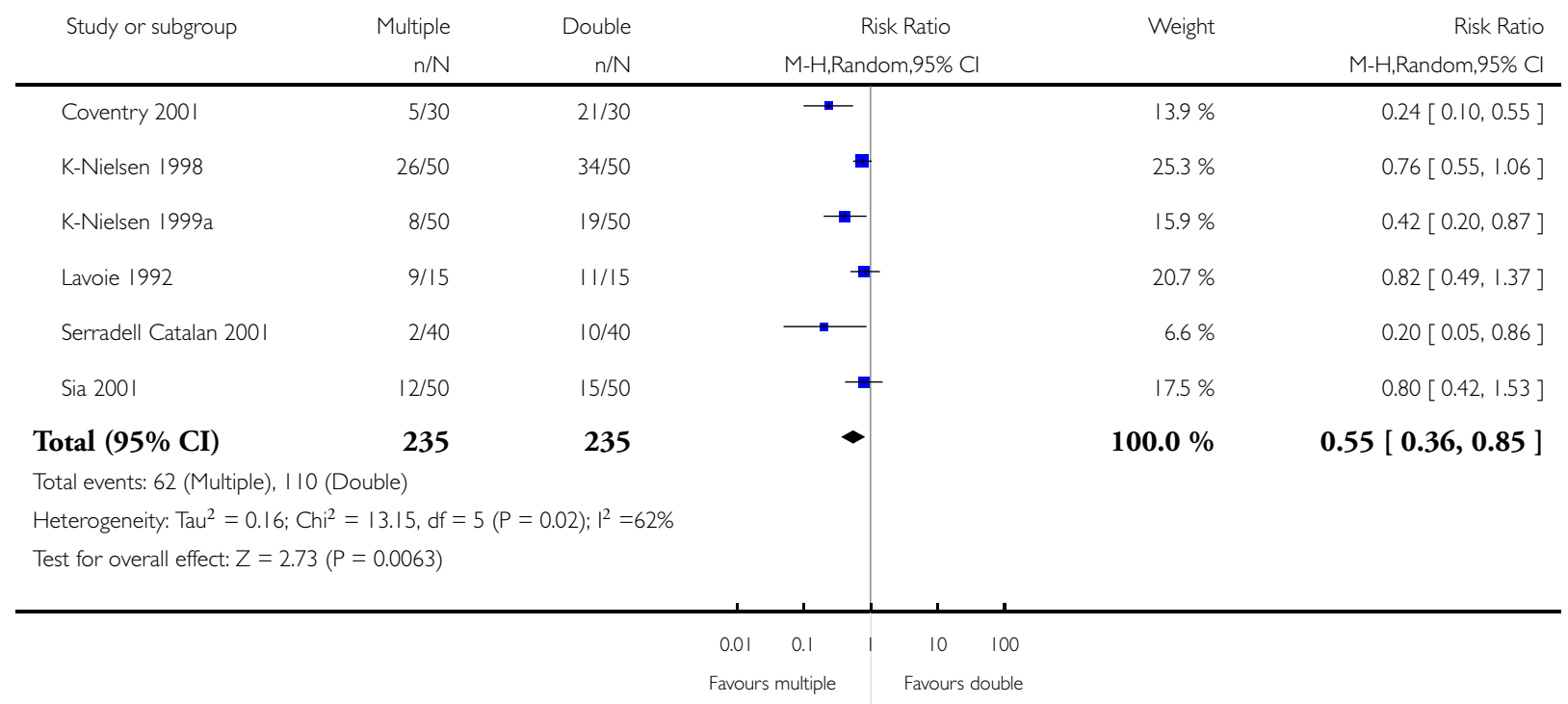


Analysis 3.5. Comparison 3 Multiple versus double-injection technique, Outcome 5 Secondary analgesia failure.

Review: Single, double or multiple-injection techniques for axillary brachial plexus block for hand, wrist or forearm surgery in adults

Comparison: 3 Multiple versus double-injection technique

Outcome: 5 Secondary analgesia failure

Study or subgroup $\quad$ Multiple Double Risk Ratio Risk Ratio

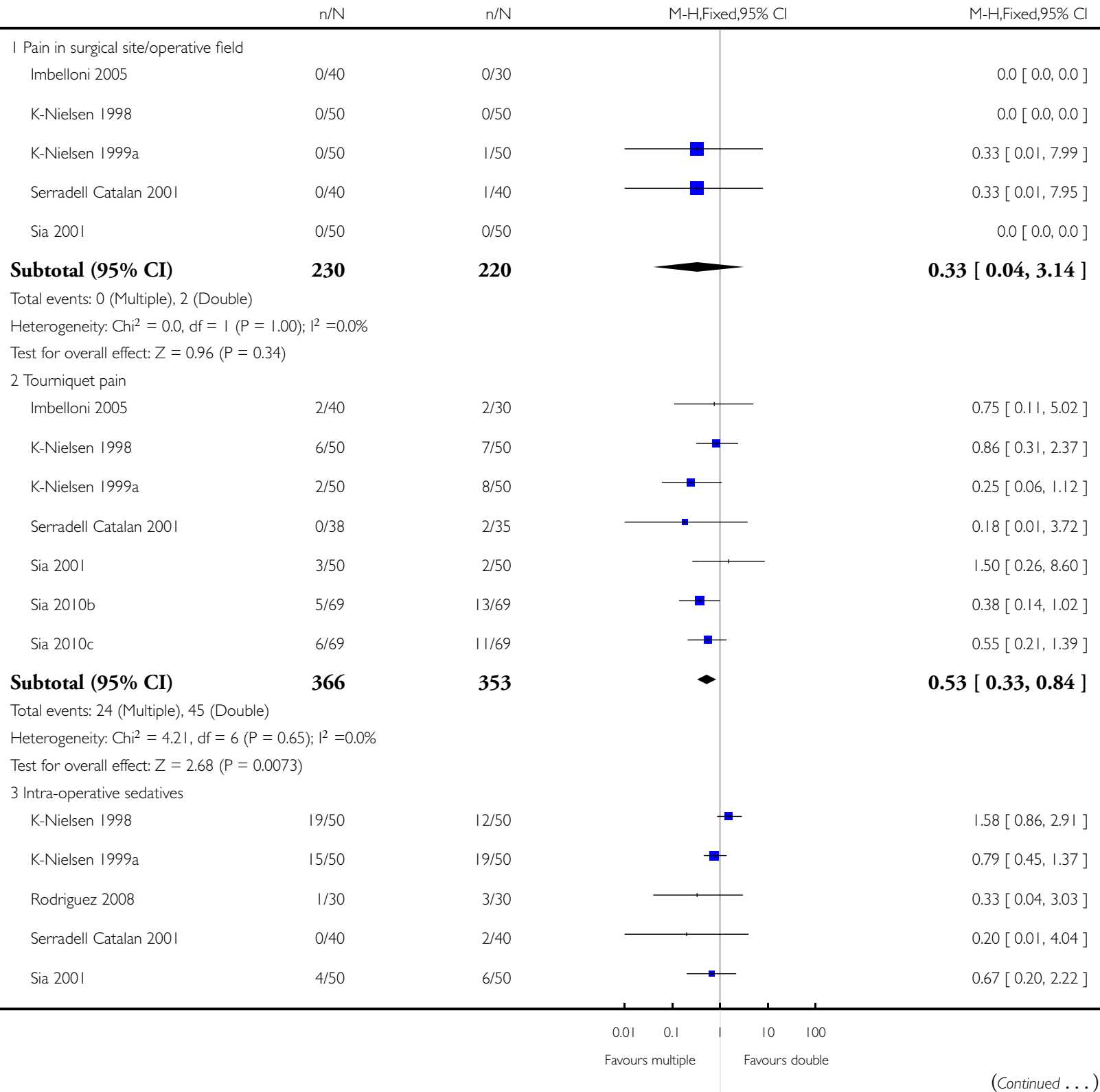

Single, double or multiple-injection techniques for axillary brachial plexus block for hand, wrist or forearm surgery in adults (Review) 


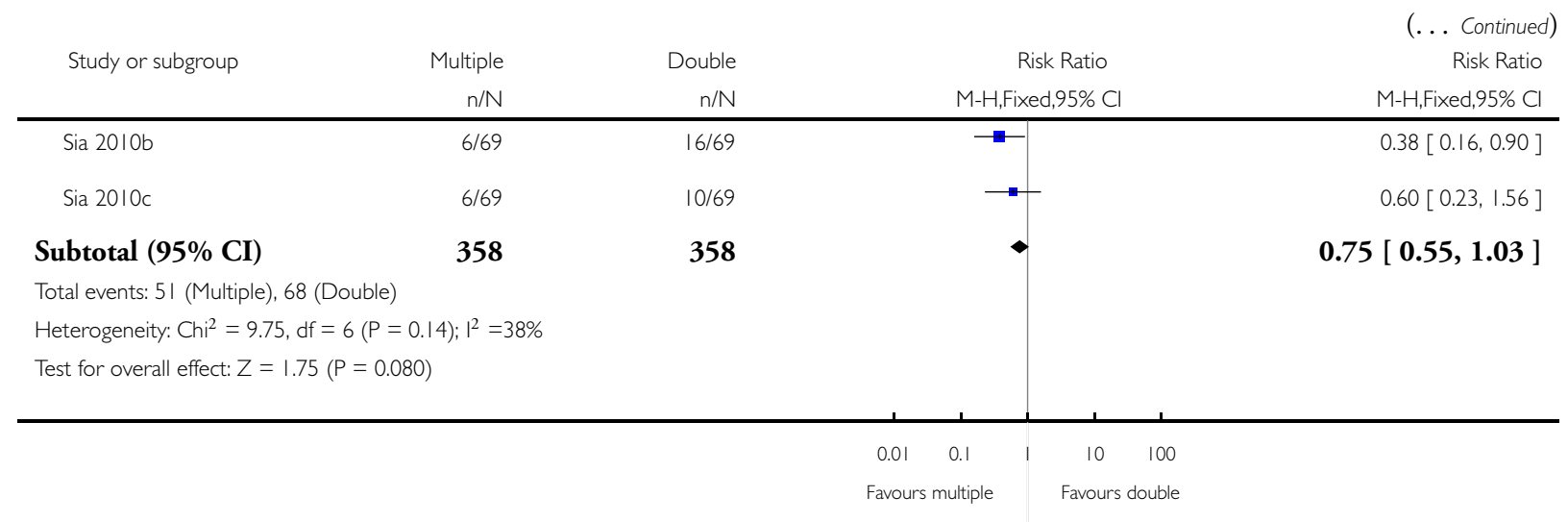

\section{Analysis 3.6. Comparison 3 Multiple versus double-injection technique, Outcome 6 Timing (in minutes).}

Review: Single, double or multiple-injection techniques for axillary brachial plexus block for hand, wrist or forearm surgery in adults

Comparison: 3 Multiple versus double-injection technique

Outcome: 6 Timing (in minutes)

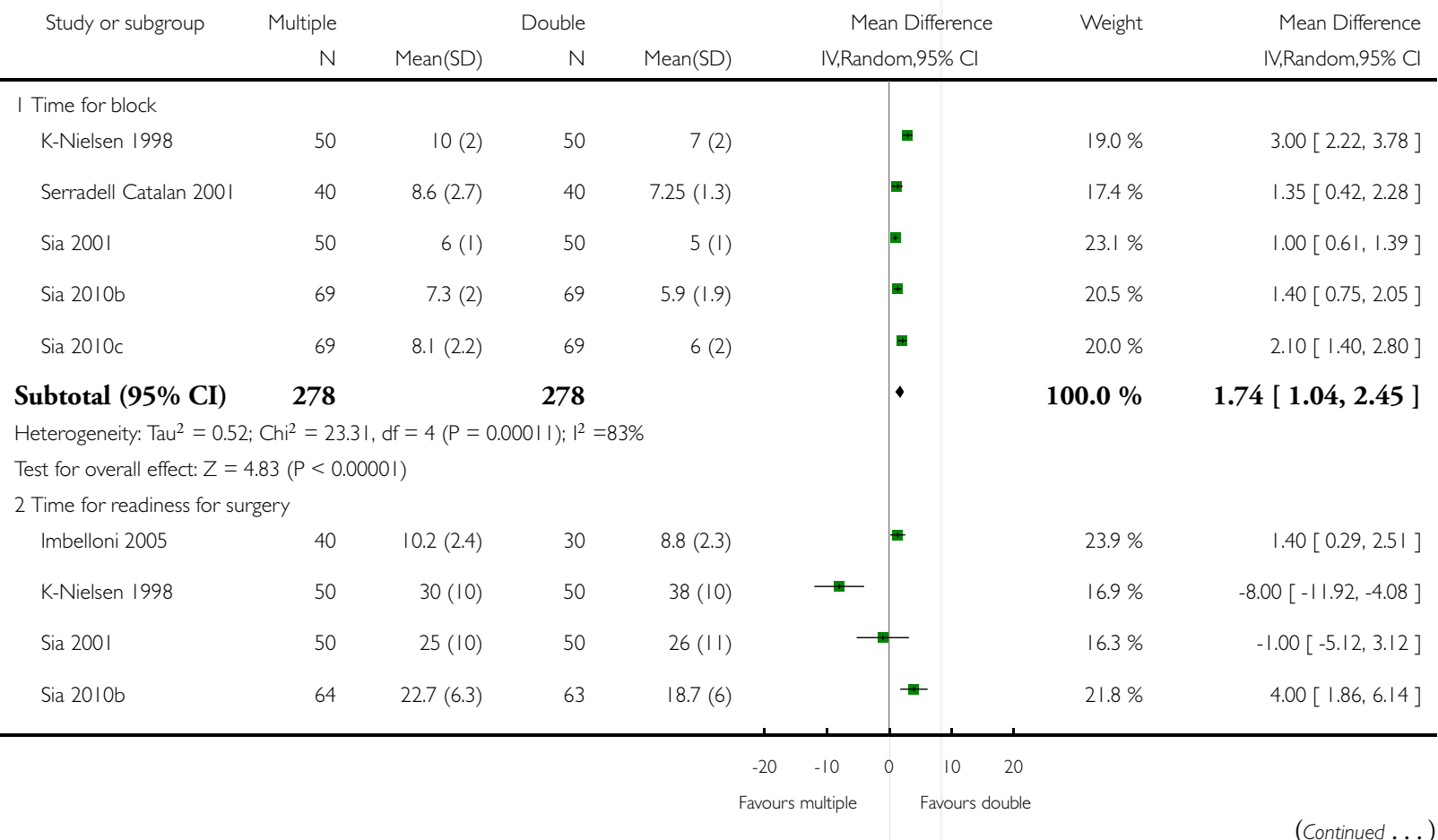




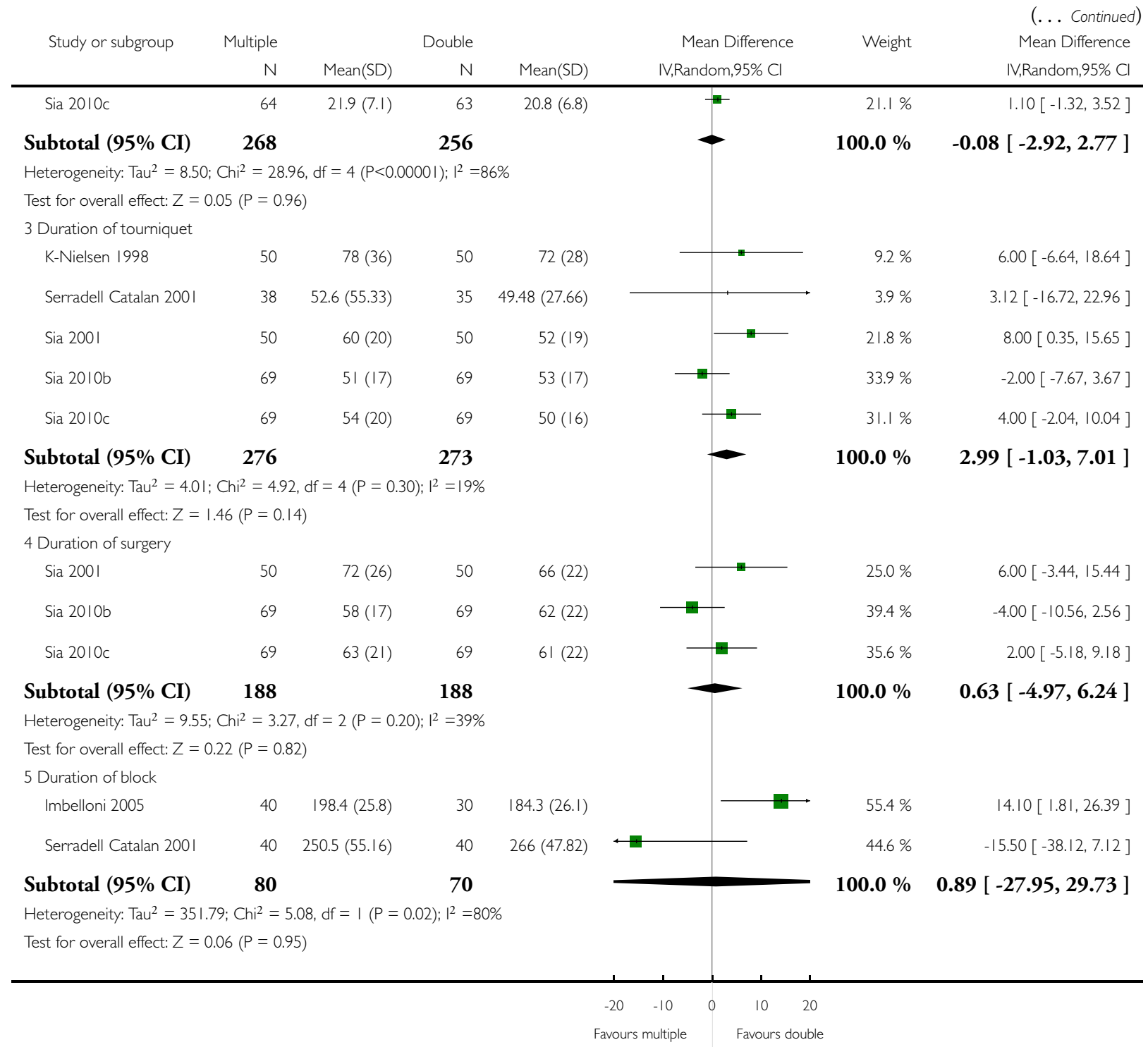


Analysis 3.7. Comparison 3 Multiple versus double-injection technique, Outcome 7 Complications during nerve block.

Review: Single, double or multiple-injection techniques for axillary brachial plexus block for hand, wrist or forearm surgery in adults

Comparison: 3 Multiple versus double-injection technique

Outcome: 7 Complications during nerve block

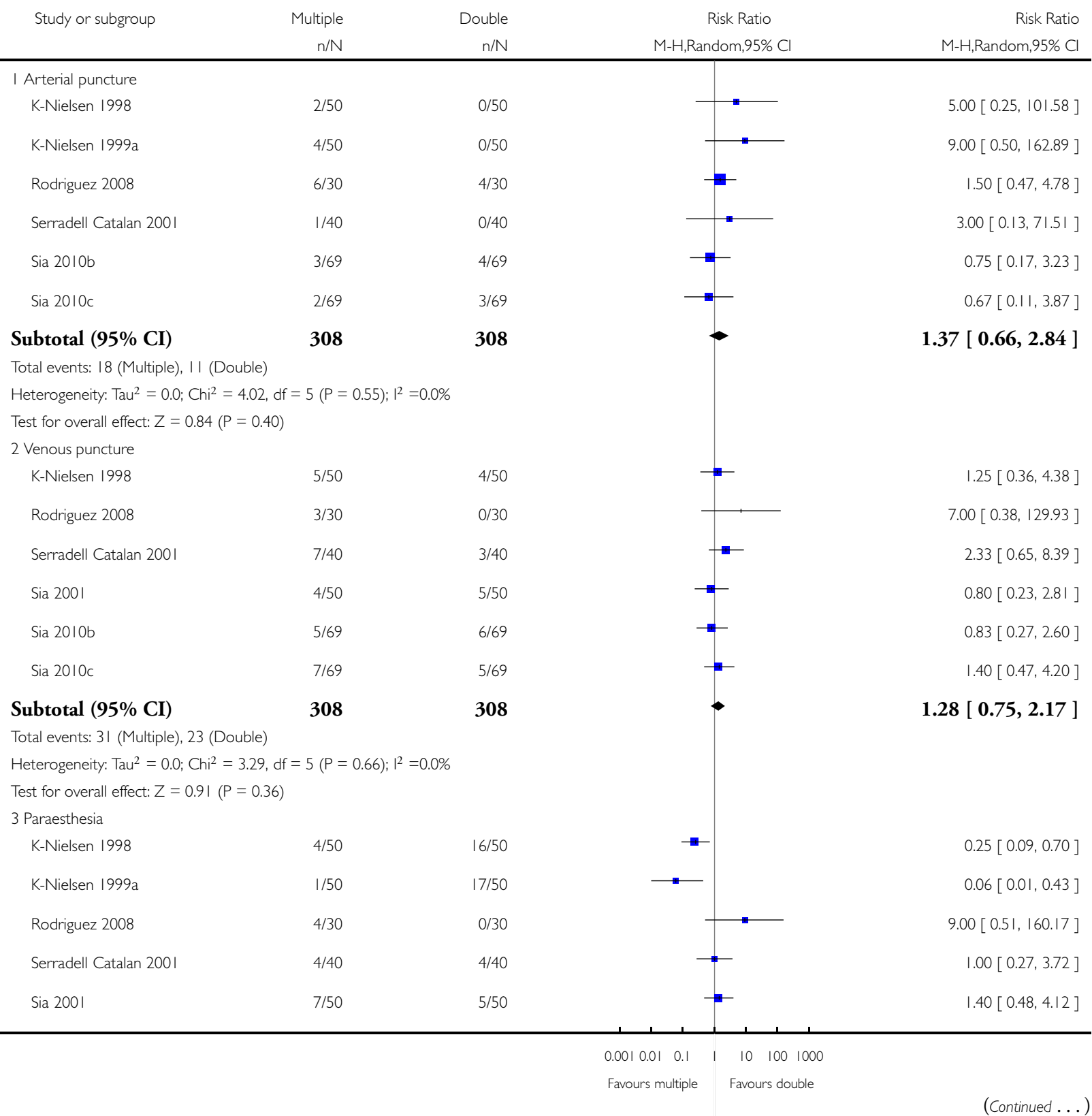

Single, double or multiple-injection techniques for axillary brachial plexus block for hand, wrist or forearm surgery in adults (Review) 


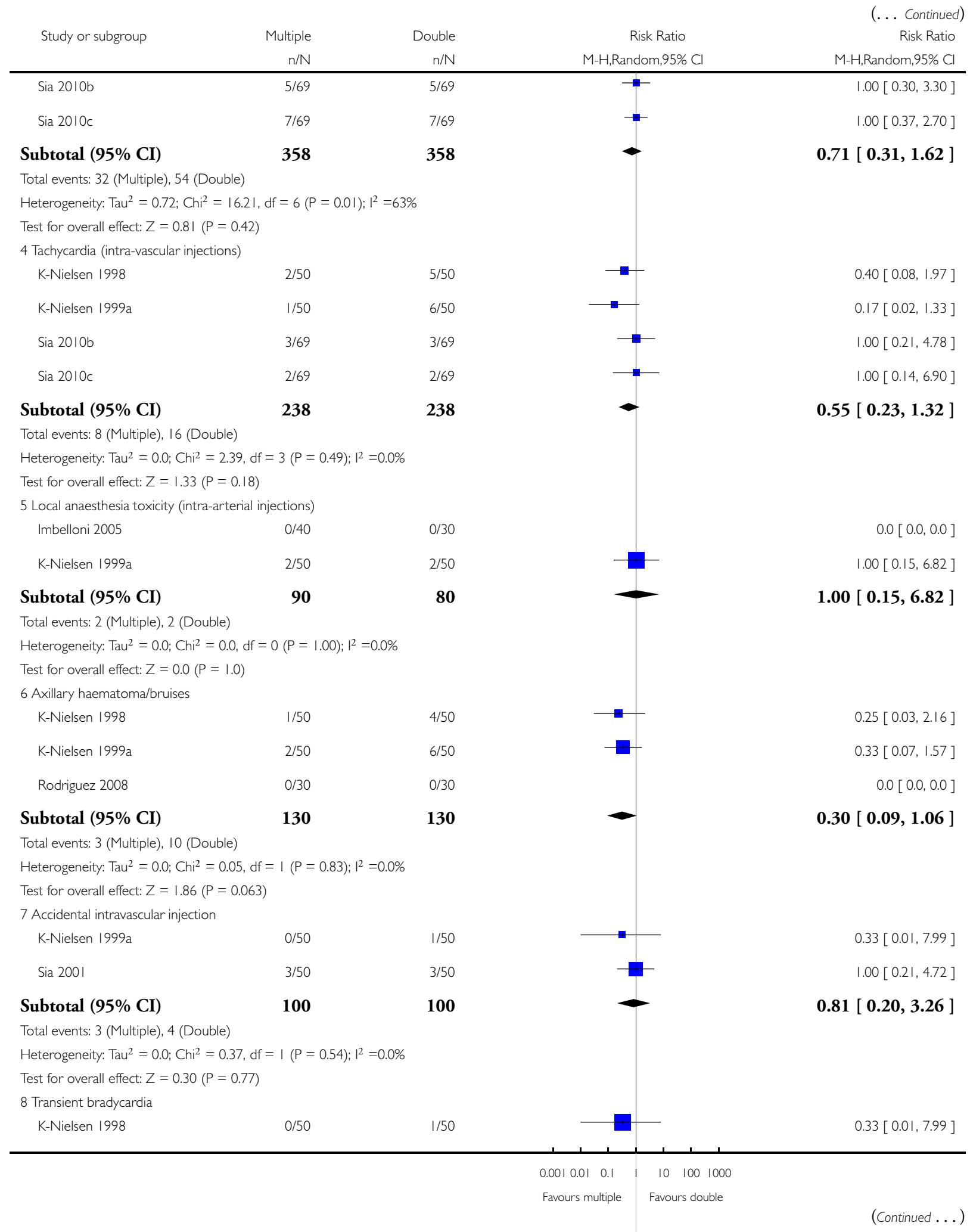




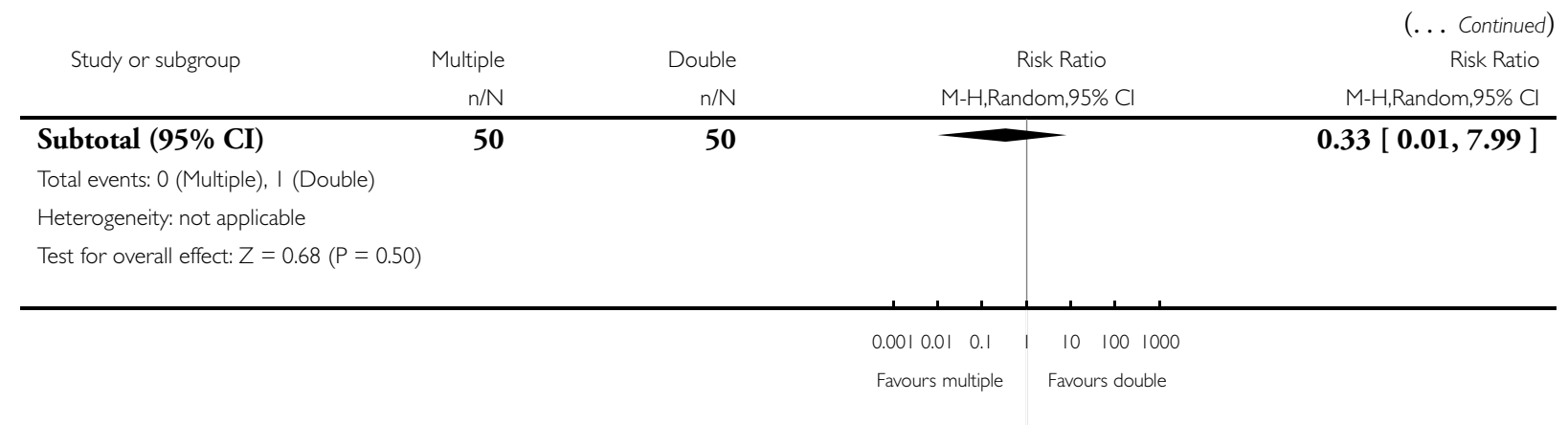

Analysis 3.8. Comparison 3 Multiple versus double-injection technique, Outcome 8 Adverse effects $>24$ hours.

Review: Single, double or multiple-injection techniques for axillary brachial plexus block for hand, wrist or forearm surgery in adults

Comparison: 3 Multiple versus double-injection technique

Outcome: 8 Adverse effects $>24$ hours

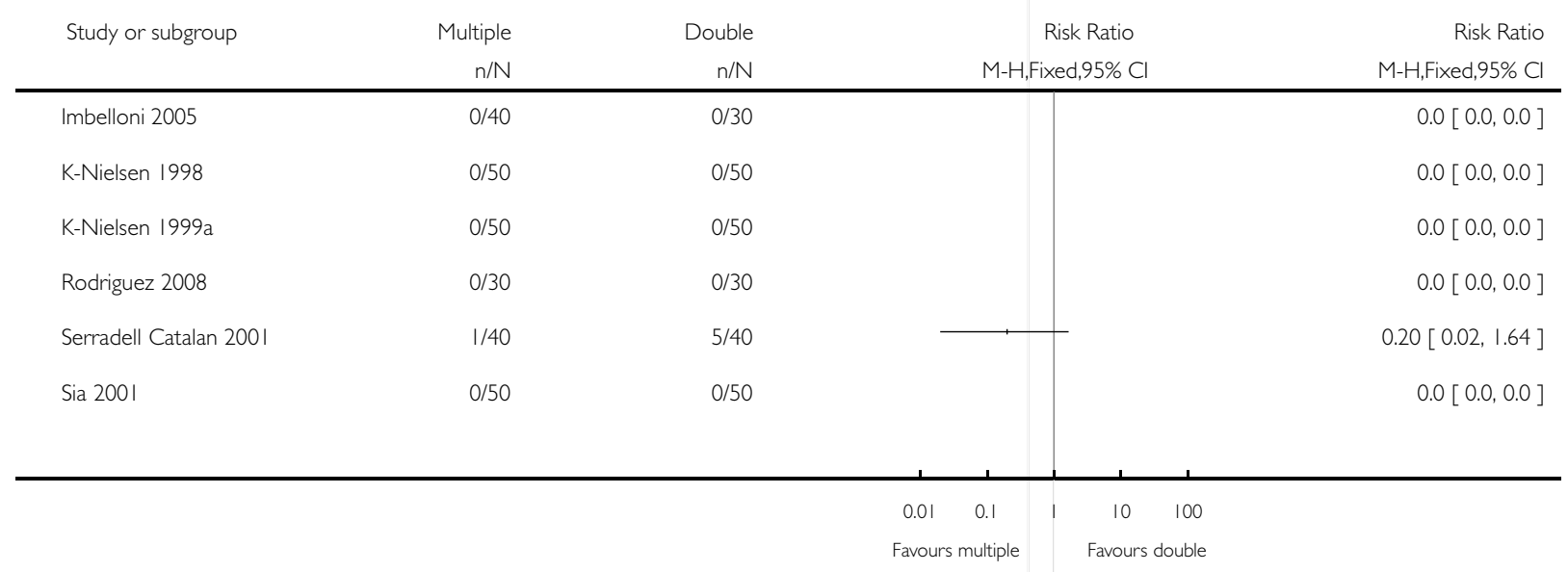


Analysis 3.9. Comparison 3 Multiple versus double-injection technique, Outcome 9 Patient discomfort and dissatisfaction with method.

Review: Single, double or multiple-injection techniques for axillary brachial plexus block for hand, wrist or forearm surgery in adults

Comparison: 3 Multiple versus double-injection technique

Outcome: 9 Patient discomfort and dissatisfaction with method

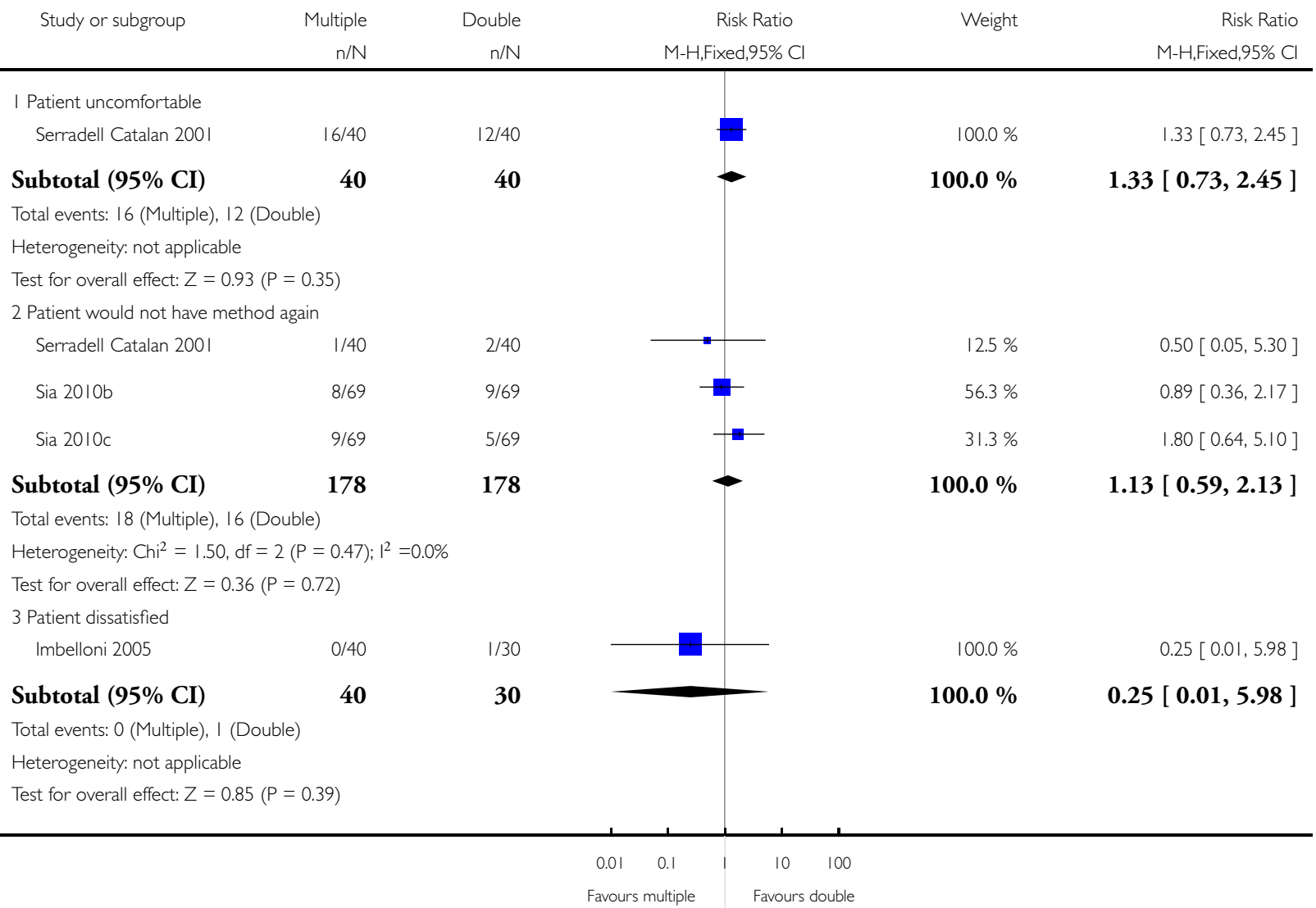




\section{A P P E N D I CES}

\section{Appendix I. Search strategies for current update}

\section{CENTRAL, The Cochrane Library}

\#1 MeSH descriptor Anesthesia, Conduction, this term only

\#2 MeSH descriptor Anesthesia, Local, this term only

\#3 MeSH descriptor Nerve Block, this term only

\#4 ((analg* or an?esth $\left.{ }^{*}\right)$ near (local ${ }^{*}$ or regional)):ti,ab

\#5 (par?esthes* or dys?esthes* or h?ematom* or seizur*):ti,ab

\#6 (pain near (per?operativ* or post?operativ*)):ti,ab

\#7 (\#1 OR \#2 OR \#3 OR \#4 OR \#5 OR \#6)

\#8 (surg* near (hand* or wrist* or forearm* ${ }^{*}$ or elbow*))

\#9 (\#7 AND \#8)

\#10 (((brachial or axillary) near (block* or an?esthesia)) or midhumer*):ti,ab

\#11 (\#9 OR \#10)

\section{EMBASE (Ovid SP)}

1 regional anesthesia/ or local anesthesia/ or nerve block/ or ((exp brachial plexus/ or exp axilla/) and block*.mp.) or ((analg* or an? esth $^{*}$ ) adj3 (local* or regional)).ti,ab. or (par?esthes* or dys?esthes* or h?ematom* or seizur*).ti,ab. or (pain adj3 (per?operativ* or post? operativ*)).ti,ab.

2 exp hand surgery/ or ( $\operatorname{surg}^{*}$ adj3 (hand* or wrist* or forearm* or elbow*)).ti,ab.

31 and 2

4 (((brachial or axillary) adj3 (block* or an?esthesia)) or midhumer*).ti.

53 or 4

\section{Ovid MEDLINE(R)}

1 Anesthesia-Conduction/ or Anesthesia-Local/ or Nerve Block/ or ((exp Brachial-Plexus/ or exp Axilla-/) and block*.mp.) or ((analg* or an?esth*) adj3 (local* or regional)).ti,ab. or Postoperative-Complications/ or Pain-Postoperative/ or (par?esthes* or dys? esthes* or h? ematom* or seizur*).ti,ab. or (pain adj3 (per?operativ* or post?operativ*)).ti,ab.

2 (exp Surgery/ and exp Hand/) or (surg* adj3 (hand* or wrist* or forearm* or elbow*)).ti,ab.

31 and 2

4 (((brachial or axillary) adj3 (block* or an?esthesia)) or midhumer*).ti.

53 or 4

\section{Appendix 2. Search strategies in first version of review (Handoll 2006)}

We searched the following databases: the Cochrane Central Register of Controlled Trials (CENTRAL), MEDLINE and EMBASE.

\section{Author-led literature search}

One author (ZK-N) performed literature searches up to August 2004 and identified RCTs using the following strategy:

1. Searching MEDLINE (OVID-WEB) from 1966 to August 2004 using a series of free-text and MESH terms (see below). The results from each term were inspected in turn.

2. Using similar search terms (free text and MESH) for EMBASE (OVID-WEB) from 1988 to August 2004, and the Cochrane Central Register of Controlled Trials (CENTRAL) (The Cochrane Library Issue 3, 2004).

3. Checking reference lists of RCTs identified through the electronic searches.

4. Contacting trial authors and the medical industry.

5. Scruntiny of article titles of the following anaesthesia journals for mention of axillary or midhumeral block:

- Acta Anaesthesiologica Scandinavica (1980 to 2004)

- Anaesthesia (1980 to 2004)

- Anaesthesia and Intensive Care (1980 to 2004)

- Anesthesia \& Analgesia (1980 to 2004)

- Anesthesiology (1980 to 2004)

- British Journal of Anaesthesia (1980 to 2004)

Single, double or multiple-injection techniques for axillary brachial plexus block for hand, wrist or forearm surgery in adults (Review)

Copyright (C) 201 I The Cochrane Collaboration. Published by John Wiley \& Sons, Ltd. 
- Canadian Journal of Anaesthesia (1980 to 2004)

- European Journal of Anaesthesiology (1990 to 2004)

- Regional Anesthesia/Regional Anesthesia \& Pain Medicine (1985 to 2004)

\section{Supplementary search}

Karen Hovhannisyan ((KH) Trial Search Co-ordinator, Cochrane Anaesthesia Review Group (CARG)) supplemented these searches up to March 2005 on CENTRAL, MEDLINE and EMBASE.

- CENTRAL (Issue 1, 2005);

- SilverPlatter MEDLINE (WebSPIRS) (up to April Week 3 2005/04);

- SilverPlatter EMBASE (WebSPIRS) (up to 2005/03).

$\mathrm{KH}$ combined the subject-specific terms for MEDLINE and EMBASE with optimal search strategies for RCTs for these databases. We applied no language restrictions.

\section{MEDLINE (Ovid-Web) search terms}

\begin{tabular}{|c|c|}
\hline Search number & Search term \\
\hline$\# 1$ (Free terms) & $\begin{array}{l}\text { Search axillary or midhumeral block } \\
\text { Field: All Fields, Limits: All Adult: 19+ years, Publication Date from } 1966 \text { to 2004, only items with abstracts, } \\
\text { Randomized Controlled Trial, Humans }\end{array}$ \\
\hline \#2 (Free terms) & $\begin{array}{l}\text { Search anesthesia and axillary or midhumeral block } \\
\text { Limits: All Adult: 19+ years, Publication Date from } 1966 \text { to 2004, only items with abstracts, Randomized Con- } \\
\text { trolled Trial, Humans }\end{array}$ \\
\hline \#3 (Free terms) & $\begin{array}{l}\text { Search plexus anesthesia and axillary or midhumeral } \\
\text { Limits: All Adult: 19+ years, Publication Date from } 1966 \text { to 2004, only items with abstracts, Randomized Con- } \\
\text { trolled Trial, Humans }\end{array}$ \\
\hline \#4 (Free terms) & $\begin{array}{l}\text { Search anesthesia and brachial plexus and surgery } \\
\text { Limits: All Adult: 19+ years, Publication Date from } 1966 \text { to 2004, only items with abstracts, Randomized Con- } \\
\text { trolled Trial, Humans }\end{array}$ \\
\hline \#5 (Free terms) & $\begin{array}{l}\text { Search anesthesia and brachial plexus and injection } \\
\text { Limits: All Adult: 19+ years, Publication Date from } 1966 \text { to 2004, only items with abstracts, Randomized Con- } \\
\text { trolled Trial, Humans }\end{array}$ \\
\hline \#6 (Free terms) & $\begin{array}{l}\text { Search nerve block and brachial plexus and injection technique } \\
\text { Limits: All Adult: 19+ years, Publication Date from } 1966 \text { to 2004, only items with abstracts, Randomized Con- } \\
\text { trolled Trial, Humans }\end{array}$ \\
\hline \#7 (Free terms) & $\begin{array}{l}\text { Search axillary or midhumeral block and injection technique } \\
\text { Limits: All Adult: 19+ years, Publication Date from } 1966 \text { to 2004, only items with abstracts, Randomized Con- } \\
\text { trolled Trial, Humans }\end{array}$ \\
\hline \#8 (Mesh) & $\begin{array}{l}\text { Search anesthesia,conduction and brachial plexus } \\
\text { Limits: All Adult: 19+ years, Publication Date from } 1966 \text { to 2004, only items with abstracts, Randomized Con- } \\
\text { trolled Trial, Humans }\end{array}$ \\
\hline
\end{tabular}


(Continued)

\begin{tabular}{ll}
\hline \#9 (Mesh) & $\begin{array}{l}\text { Search anesthesia,conduction and brachial plexus and axilla } \\
\text { Limits: All Adult: 19+ years, Publication Date from } 1966 \text { to 2004, only items with abstracts, Randomized Con- } \\
\text { trolled Trial, Humans }\end{array}$ \\
\hline \#10 (Mesh) & $\begin{array}{l}\text { Search anesthesia,conduction and surgery,hand } \\
\text { Limits: All Adult: 19+ years, Publication Date from } 1966 \text { to 2004, only items with abstracts, Randomized Con- } \\
\text { trolled Trial, Humans }\end{array}$ \\
\hline \#11 (Mesh) & $\begin{array}{l}\text { Search nerve block and surgery,hand } \\
\text { Limits: All Adult: 19+ years, Publication Date from } 1966 \text { to 2004, only items with abstracts, Randomized Con- } \\
\text { trolled Trial, Humans }\end{array}$ \\
\hline \#12 (Mesh) & $\begin{array}{l}\text { Search nerve block and brachial plexus } \\
\text { Limits: All Adult: 19+ years, Publication Date from } 1966 \text { to 2004, only items with abstracts, Randomized Con- } \\
\text { trolled Trial, Humans }\end{array}$ \\
\hline \#13 (Mesh) & $\begin{array}{l}\text { Search nerve block and axilla } \\
\text { Limits: All Adult: } 19+\text { years, Publication Date from } 1966 \text { to 2004, only items with abstracts, Randomized Con- } \\
\text { trolled Trial, Humans }\end{array}$ \\
\hline \#14 (Mesh) & $\begin{array}{l}\text { Search nerve block and axilla and surgery } \\
\text { Limits: All Adult: } 19+\text { years, Publication Date from } 1966 \text { to 2004, only items with abstracts, Randomized Con- } \\
\text { trolled Trial, Humans }\end{array}$ \\
\hline
\end{tabular}

\section{Appendix 3. Former methodological quality assessment tool}

\begin{tabular}{l|l}
\hline Item & Score \\
\hline $\begin{array}{l}\text { 1. Was the assigned treatment adequately concealed prior to allo- } \\
\text { cation? }\end{array}$ & $\begin{array}{l}3 \text { = allocation was concealed (e.g. sequentially numbered, sealed, } \\
\text { opaque envelopes) } \\
2=\text { small but possible chance of disclosure of assignment } \\
1=\text { states random but no description } \\
0=\text { quasi-randomized or open list/tables }\end{array}$ \\
\hline $\begin{array}{l}\text { 2. Were the inclusion and exclusion criteria for entry clearly de- } \\
\text { fined? }\end{array}$ & $\begin{array}{l}1=\text { clearly defined (including contra-indications) } \\
0=\text { inadequately or not defined }\end{array}$ \\
\hline $\begin{array}{l}\text { 3. Were the outcomes of patients who withdrew described and } \\
\text { included in the analysis (intention-to-treat)? }\end{array}$ & $\begin{array}{l}1=\text { Outcomes of patients who withdrew or were excluded after } \\
\text { allocation were EITHER detailed separately OR included in an } \\
\text { intention-to-treat analysis OR the text stated there were no with- } \\
\text { drawals } \\
0=\text { Outcomes of patients who withdrew or were excluded after } \\
\text { allocation were NEITHER detailed separately NOR included in }\end{array}$ \\
\hline
\end{tabular}



minimum of 3 admission details were described: age, sex, type of surgery, mental status.

$0=$ Intervention groups were NOT adequately described at entry

5. Were care programmes, other than the trial options, identical? (Example of a clinically important difference is anaesthetist experience)

6. Were the outcome measures used clearly defined?

7. Were the outcome assessors blinded to treatment status?

$1=$ Outcome assessors were blind to the allocation of patients $0=$ Not mentioned or outcome assessors were NOT blind to the allocation of patients

8. Was the timing (e.g. duration of surveillance) clinically appropriate?

$1=$ The timing of the measurement of the outcomes was appropriate (e.g. at least 24 hours)

$0=$ The timing of the measurement of the outcomes was NOT appropriate

\section{Appendix 4. Measurement of sensory and motor blockade}

\begin{tabular}{|c|c|c|c|c|c|c|c|}
\hline Study ID & $\begin{array}{l}\text { Sensory: } \\
\text { method }\end{array}$ & $\begin{array}{l}\text { Sensory: tim- } \\
\text { ing }\end{array}$ & $\begin{array}{l}\text { Sensory: rat- } \\
\text { ing }\end{array}$ & $\begin{array}{l}\text { Nerve areas } \\
\text { tested }\end{array}$ & $\begin{array}{l}\text { Nerves: block } \\
\text { Y/N? }\end{array}$ & Motor: rating & Nerves tested \\
\hline $\begin{array}{l}\text { Baranowski } \\
1990\end{array}$ & $\begin{array}{l}\text { Use of } \\
\text { blunt end of a } \\
27 \text { gauge den- } \\
\text { tal needle }\end{array}$ & $\begin{array}{l}\text { Every } 5 \\
\text { minutes for } 30 \\
\text { minutes }\end{array}$ & $\begin{array}{l}0=\text { no sensory } \\
\text { loss } \\
1=\text { loss of pin- } \\
\text { prick } \\
2=\text { loss of } \\
\text { touch }\end{array}$ & $\begin{array}{l}\text { Axillary } \\
\text { Medial cuta- } \\
\text { neous nerve of } \\
\text { arm } \\
\text { Medial cuta- } \\
\text { neous nerve of } \\
\text { forearm } \\
\text { Median } \\
\text { Musculocuta- } \\
\text { neous } \\
\text { Radial } \\
\text { Ulnar }\end{array}$ & $\begin{array}{l}\text { Success = } 3 \text { or } \\
4 \\
\text { of the follow- } \\
\text { ing } 4 \text { nerves } \\
\text { were blocked } \\
\text { to sensory loss } \\
\text { score of } 2 \text { (loss } \\
\text { of touch) at } 30 \\
\text { minutes: } \\
\text { Median } \\
\text { Musculocuta- } \\
\text { neous } \\
\text { Radial } \\
\text { Ulnar }\end{array}$ & Not reported & Not reported \\
\hline
\end{tabular}




\begin{tabular}{|c|c|c|c|c|c|c|c|}
\hline $\begin{array}{l}\text { Coventry } \\
2001\end{array}$ & $\begin{array}{l}\text { Use of a short- } \\
\text { bevelled } 27 \\
\text { gauge needle }\end{array}$ & $\begin{array}{l}\text { Every } 10 \\
\text { minutes for } 30 \\
\text { minutes }\end{array}$ & $\begin{array}{l}\text { Complete sen- } \\
\text { sory loss }\end{array}$ & $\begin{array}{l}\text { Medial cuta- } \\
\text { neous nerve of } \\
\text { arm } \\
\text { Medial cuta- } \\
\text { neous nerve of } \\
\text { fore arm } \\
\text { Median } \\
\text { Musculocuta- } \\
\text { neous } \\
\text { Radial } \\
\text { Ulnar }\end{array}$ & $\begin{array}{l}\text { Success = sen- } \\
\text { sory blockade } \\
\text { of } 6 \text { nerves: } \\
\text { Median } \\
\text { Medial cuta- } \\
\text { neous nerve of } \\
\text { arm } \\
\text { Medial cuta- } \\
\text { neous nerve of } \\
\text { forearm } \\
\text { Musculocuta- } \\
\text { neous } \\
\text { Radial } \\
\text { Ulnar }\end{array}$ & $\begin{array}{l}\text { Inability to } \\
\text { move relevant } \\
\text { muscle groups } \\
\text { against gravity }\end{array}$ & $\begin{array}{l}\text { Blockade } \\
\text { of } 4 \text { nerves re- } \\
\text { ported: } \\
\text { Median } \\
\text { Musculocuta- } \\
\text { neous } \\
\text { Radial } \\
\text { Ulnar }\end{array}$ \\
\hline $\begin{array}{l}\text { Goldberg } \\
1987\end{array}$ & $\begin{array}{l}\text { Skin pinched } \\
\text { with Allis } \\
\text { clamp }\end{array}$ & Not stated & $\begin{array}{l}\text { No pain on } \\
\text { pinching the } \\
\text { skin }\end{array}$ & $\begin{array}{l}\text { Median } \\
\text { Musculocuta- } \\
\text { neous } \\
\text { Radial } \\
\text { Ulnar }\end{array}$ & $\begin{array}{l}\text { Success }=\text { sen- } \\
\text { sory blockade } \\
\text { (no pain) for } \\
\text { all } 4 \text { nerves: } \\
\text { Median } \\
\text { Musculocuta- } \\
\text { neous } \\
\text { Radial } \\
\text { Ulnar }\end{array}$ & Not reported & Not reported \\
\hline Hickey 1993 & Pinprick & $\begin{array}{l}2,5,10,15, \\
20,25 \text { and } 30 \\
\text { min- } \\
\text { utes following } \\
\text { injection }\end{array}$ & $\begin{array}{l}0=\text { no loss } \\
\text { of sensation to } \\
\text { pinprick } \\
1=\text { analge- } \\
\text { sia (patient felt } \\
\text { touch but not } \\
\text { sharp) } \\
2=\text { anaesthesia } \\
\text { (patient did } \\
\text { not feel touch) }\end{array}$ & $\begin{array}{l}\text { Axillary } \\
\text { Musculocuta- } \\
\text { neousMedian } \\
\text { Radial } \\
\text { Ulnar } \\
\text { Medial } \\
\text { brachial cuta- } \\
\text { neous } \\
\text { Medial ante- } \\
\text { brachial cuta- } \\
\text { neous } \\
\text { Intercosto- } \\
\text { brachial }\end{array}$ & $\begin{array}{l}\text { Overall block } \\
\text { success was } \\
\text { not strictly de- } \\
\text { fined. Instead } \\
\text { they looked } \\
\text { primar- } \\
\text { ily at anaesthe- } \\
\text { sia and analge- } \\
\text { sia in individ- } \\
\text { ual nerve terri- } \\
\text { tories }\end{array}$ & $\begin{array}{l}\text { Hand grip } \\
0=\text { no weak- } \\
\text { ness } \\
1=\text { paresis } \\
2=\text { paralysis }\end{array}$ & Not reported \\
\hline $\begin{array}{l}\text { Imbelloni } \\
2005\end{array}$ & $\begin{array}{l}\text { Skin clamp } \\
\text { and "observ- } \\
\text { ing patients' } \\
\text { pain manifes- } \\
\text { tations" }\end{array}$ & Not stated & $\begin{array}{l}\text { Not stated. } \\
\text { The } \\
\text { term "analge- } \\
\text { sia" is used. }\end{array}$ & $\begin{array}{l}\text { Musculocuta- } \\
\text { neous } \\
\text { Median } \\
\text { Ulnar } \\
\text { Radial }\end{array}$ & $\begin{array}{l}\text { "Blockade was } \\
\text { considered } \\
\text { complete if } \\
\text { all nerves were } \\
\text { blocked". } \\
\text { Incomplete = } \\
\text { "need for ad- } \\
\text { ditional injec- } \\
\text { tion". } \\
\text { Fail- }\end{array}$ & Not reported & Not reported \\
\hline
\end{tabular}


(Continued)

\begin{tabular}{|c|c|c|c|c|c|c|c|}
\hline & & & & & $\begin{array}{l}\text { ure }=\text { "need for } \\
\text { general anes- } \\
\text { thesia". }\end{array}$ & & \\
\hline Inberg 1999 & Skin pinched & 40 minutes & $\begin{array}{l}0=\text { normal } \\
\text { sensation } \\
1=\text { hypalgesia } \\
2=\text { analgesia } \\
3=\text { anaesthesia }\end{array}$ & $\begin{array}{l}\text { Axillary } \\
\text { Lateral } \\
\text { cutaneous } \\
\text { Medial cuta- } \\
\text { neous } \\
\text { Median } \\
\text { Musculocuta- } \\
\text { neous } \\
\text { Radial } \\
\text { Ulnar }\end{array}$ & 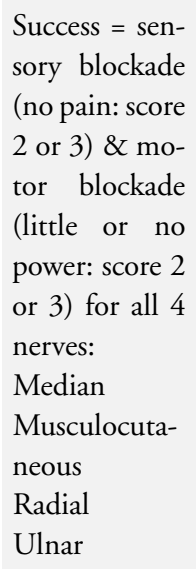 & $\begin{array}{l}0 \\
=\text { normal mus- } \\
\text { cular function } \\
1=\text { slight de- } \\
\text { pression of } \\
\text { power } \\
2=\text { weak func- } \\
\text { tion without } \\
\text { power } \\
3=\text { no muscu- } \\
\text { lar function }\end{array}$ & $\begin{array}{l}\text { Median } \\
\text { Musculocuta- } \\
\text { neous } \\
\text { Radial } \\
\text { Ulnar }\end{array}$ \\
\hline $\begin{array}{l}\text { K-Nielsen } \\
1997\end{array}$ & $\begin{array}{l}\text { Painful pinch } \\
\text { with a plastic } \\
\text { clamp }\end{array}$ & $\begin{array}{l}\text { Every } 10 \text { min- } \\
\text { utes } \\
\text { until ready for } \\
\text { surgery; sup- } \\
\text { plemen- } \\
\text { tation from } 20 \\
\text { minutes }\end{array}$ & $\begin{array}{l}0=\text { no analge- } \\
\text { sia/ } \\
\text { anaesthesia } \\
1=\text { loss of } \\
\text { pain } \\
2=\text { loss of sen- } \\
\text { sation }\end{array}$ & $\begin{array}{l}\text { Axillary } \\
\text { Medial cuta- } \\
\text { neous nerve of } \\
\text { arm } \\
\text { Medial cuta- } \\
\text { neous nerve of } \\
\text { forearm } \\
\text { Median } \\
\text { Musculocuta- } \\
\text { neous } \\
\text { Radial } \\
\text { Ulnar }\end{array}$ & $\begin{array}{l}\text { Success = no } \\
\text { need to sup- } \\
\text { plement any } \\
\text { of } 4 \text { nerves: } \\
\text { Median } \\
\text { Musculocu- } \\
\text { taneous (only } \\
\text { if necessary for } \\
\text { surgery) } \\
\text { Radial } \\
\text { Ulnar }\end{array}$ & $\begin{array}{l}\text { Poor }= \\
\text { no obvious re- } \\
\text { laxation } \\
\text { Satisfactory = } \\
\text { minor move- } \\
\text { ment of digits } \\
\text { Good = com- } \\
\text { pletely limp } \\
\text { hand }\end{array}$ & Not reported \\
\hline $\begin{array}{l}\text { K-Nielsen } \\
1998\end{array}$ & $\begin{array}{l}\text { Painful pinch } \\
\text { with a plastic } \\
\text { clamp }\end{array}$ & $\begin{array}{l}\text { Every } 10 \text { min- } \\
\text { utes } \\
\text { until ready for } \\
\text { surgery; sup- } \\
\text { plemen- } \\
\text { tation from } 30 \\
\text { minutes }\end{array}$ & $\begin{array}{l}0=\text { no analge- } \\
\text { sia/ } \\
\text { anaesthesia } \\
1=\text { loss of } \\
\text { pain } \\
2=\text { loss of sen- } \\
\text { sation }\end{array}$ & $\begin{array}{l}\text { Axillary } \\
\text { Medial cuta- } \\
\text { neous nerve of } \\
\text { arm } \\
\text { Medial cuta- } \\
\text { neous nerve of } \\
\text { forearm } \\
\text { Median } \\
\text { Musculocuta- } \\
\text { neous } \\
\text { Radial } \\
\text { Ulnar }\end{array}$ & $\begin{array}{l}\text { Success = no } \\
\text { need to sup- } \\
\text { plement. No } \\
\text { pain felt in any } \\
\text { area below el- } \\
\text { bow. } \\
\text { Incompletely } \\
\text { blocked } \\
\text { nerves were: } \\
\text { Axillary } \\
\text { Median } \\
\text { Musculocuta- } \\
\text { neous } \\
\text { Radial } \\
\text { Ulnar }\end{array}$ & $\begin{array}{l}\text { Poor = } \\
\text { no obvious re- } \\
\text { laxation } \\
\text { Satisfactory = } \\
\text { minor move- } \\
\text { ment of digits } \\
\text { Good = com- } \\
\text { pletely limp } \\
\text { hand }\end{array}$ & Not reported \\
\hline
\end{tabular}




\begin{tabular}{|c|c|c|c|c|c|c|c|}
\hline $\begin{array}{l}\text { K-Nielsen } \\
1999 a\end{array}$ & $\begin{array}{l}\text { Painful pinch } \\
\text { with a plastic } \\
\text { clamp }\end{array}$ & $\begin{array}{l}\text { Every } 10 \text { min- } \\
\text { utes } \\
\text { until ready for } \\
\text { surgery; sup- } \\
\text { plemen- } \\
\text { tation from } 30 \\
\text { minutes }\end{array}$ & $\begin{array}{l}0=\text { no analge- } \\
\text { sia/ } \\
\text { anaesthesia } \\
1=\text { loss of } \\
\text { pain } \\
2=\text { loss of sen- } \\
\text { sation }\end{array}$ & $\begin{array}{l}\text { Axillary } \\
\text { Medial cuta- } \\
\text { neous nerve of } \\
\text { arm } \\
\text { Medial cuta- } \\
\text { neous nerve of } \\
\text { forearm } \\
\text { Median } \\
\text { Musculocuta- } \\
\text { neous } \\
\text { Radial } \\
\text { Ulnar }\end{array}$ & $\begin{array}{l}\text { Success = no } \\
\text { need to sup- } \\
\text { plement. No } \\
\text { pain felt in any } \\
\text { area below el- } \\
\text { bow. } \\
\text { Incompletely } \\
\text { blocked } \\
\text { nerves were: } \\
\text { Axillary } \\
\text { Medial cuta- } \\
\text { neous nerve of } \\
\text { arm } \\
\text { Median } \\
\text { Musculocuta- } \\
\text { neous } \\
\text { Radial } \\
\text { Ulnar }\end{array}$ & $\begin{array}{l}\text { Poor } \\
\text { no obvious re- } \\
\text { laxation } \\
\text { Satisfactory = } \\
\text { minor move- } \\
\text { ment of digits } \\
\text { Good = com- } \\
\text { pletely limp } \\
\text { hand }\end{array}$ & Not reported \\
\hline $\begin{array}{l}\text { K-Nielsen } \\
1999 \mathrm{~b}\end{array}$ & $\begin{array}{l}\text { Painful pinch } \\
\text { with a plastic } \\
\text { clamp }\end{array}$ & $\begin{array}{l}\text { Every } 10 \text { min- } \\
\text { utes } \\
\text { until ready for } \\
\text { surgery; sup- } \\
\text { plemen- } \\
\text { tation from } 30 \\
\text { minutes }\end{array}$ & $\begin{array}{l}0=\text { no analge- } \\
\text { sia/ } \\
\text { anaesthesia } \\
1=\text { loss of } \\
\text { pain } \\
2=\text { loss of sen- } \\
\text { sation }\end{array}$ & $\begin{array}{l}\text { Axillary } \\
\text { Median } \\
\text { Medial cuta- } \\
\text { neous nerve of } \\
\text { arm } \\
\text { Medial cuta- } \\
\text { neous nerve of } \\
\text { forearm } \\
\text { Musculocuta- } \\
\text { neous } \\
\text { Radial } \\
\text { Ulnar }\end{array}$ & $\begin{array}{l}\text { Success = no } \\
\text { need to sup- } \\
\text { plement. No } \\
\text { pain felt in any } \\
\text { area below el- } \\
\text { bow. } \\
\text { Incompletely } \\
\text { blocked } \\
\text { nerves were: } \\
\text { Axillary } \\
\text { Medial cuta- } \\
\text { neous nerve of } \\
\text { arm } \\
\text { Median } \\
\text { Musculocuta- } \\
\text { neous } \\
\text { Radial } \\
\text { Ulnar }\end{array}$ & $\begin{array}{l}\text { Poor } \\
\text { no obvious re- } \\
\text { laxation } \\
\text { Satisfactory = } \\
\text { minor move- } \\
\text { ment of digits } \\
\text { Good = com- } \\
\text { pletely limp } \\
\text { hand }\end{array}$ & Not reported \\
\hline
\end{tabular}

\begin{tabular}{|c|c|c|c|c|c|c|c|}
\hline Lavoie 1992 & $\begin{array}{l}\text { Use } \\
\text { of Wartenberg } \\
\text { pinwheel }\end{array}$ & $\begin{array}{l}\text { Every } 5 \mathrm{~min} \text { - } \\
\text { utes up to } 30 \\
\text { minutes }\end{array}$ & $\begin{array}{l}\text { Needles of } \\
\text { pinwheel no } \\
\text { longer felt }\end{array}$ & $\begin{array}{l}\text { "Each der- } \\
\text { matome of the } \\
\text { upper } \\
\text { limb". Nerves } \\
\text { not listed but } \\
\text { would be: } \\
\text { Axillary } \\
\text { Medial cuta- } \\
\text { neous nerve of } \\
\text { arm } \\
\text { Medial cuta- }\end{array}$ & $\begin{array}{l}\text { Success = "der- } \\
\text { matomes of } \\
\text { the nerves im- } \\
\text { plicated in the } \\
\text { surgical site } \\
\text { were anaes- } \\
\text { thetised". (All } \\
\text { nerves at sur- } \\
\text { gical site: skin, } \\
\text { muscles and }\end{array}$ & $\begin{array}{l}0 \%=\text { flexion/ } \\
\text { extension } \\
\text { movements in } \\
\text { hand and arm } \\
\text { against } \\
\text { resistance } \\
33 \%=\text { flex- } \\
\text { ion/extension } \\
\text { movements in } \\
\text { hand and arm }\end{array}$ & Not reported \\
\hline
\end{tabular}




\begin{tabular}{|c|c|c|c|c|c|c|c|}
\hline & & & & $\begin{array}{l}\text { neous nerve of } \\
\text { forearm } \\
\text { Median } \\
\text { Musculocuta- } \\
\text { neous } \\
\text { Radial } \\
\text { Ulnar }\end{array}$ & bones) & $\begin{array}{l}\text { against gravity } \\
\text { but } \\
\text { not against re- } \\
\text { sistance } \\
66 \%=\text { flex- } \\
\text { ion/extension } \\
\text { movements in } \\
\text { hand only } \\
100 \% \\
\text { no movement } \\
\text { of upper limb } \\
\text { against gravity }\end{array}$ & \\
\hline Pere 1993 & Pinprick & $\begin{array}{l}5, \\
10,20 \text { and } 30 \\
\text { minutes and } 3 \\
\text { hours; supple- } \\
\text { men- } \\
\text { tation from } 20 \\
\text { minutes }\end{array}$ & $\begin{array}{l}\text { Painful } \\
\text { pinprick / } \\
\text { pinprick anal- } \\
\text { gesia }\end{array}$ & $\begin{array}{l}\text { Axillary } \\
\text { Medial cuta- } \\
\text { neous nerve of } \\
\text { arm } \\
\text { Medial cuta- } \\
\text { neous nerve of } \\
\text { forearm } \\
\text { Median } \\
\text { Musculocuta- } \\
\text { neous } \\
\text { Radial } \\
\text { (Supraclavicu- } \\
\text { lar) } \\
\text { Ulnar }\end{array}$ & $\begin{array}{l}\text { Success = no } \\
\text { supplementa- } \\
\text { tion of nerves } \\
\text { at } \\
\text { site of planned } \\
\text { surgery } \\
\text { Incompletely } \\
\text { blocked } \\
\text { nerves were: } \\
\text { Axillary } \\
\text { Median } \\
\text { Medial cuta- } \\
\text { neous nerve of } \\
\text { arm } \\
\text { Medial cuta- } \\
\text { neous nerve of } \\
\text { forearm } \\
\text { Musculocuta- } \\
\text { neous } \\
\text { Radial } \\
\text { Supraclavicu- } \\
\text { lar } \\
\text { Ulnar }\end{array}$ & $\begin{array}{l}\text { Strength of ex- } \\
\text { tensors and } \\
\text { flexors: } \\
\text { No reduction } \\
\text { in strength / } \\
\text { reduced } \\
\text { strength } \\
\text { / no muscular } \\
\text { movement } \\
\text { Grip strength } \\
\text { (kg/ cm2): } 0 \text { / } \\
0.1-0.4 />0.4\end{array}$ & Not reported \\
\hline $\begin{array}{l}\text { Rodriguez } \\
2005\end{array}$ & $\begin{array}{l}\text { Pinprick } \\
\text { with } 18 \mathrm{G} \text { long } \\
\text { bevel needle }\end{array}$ & $\begin{array}{l}5,20 \text { minutes } \\
\text { after block } \\
\text { completion }\end{array}$ & $\begin{array}{l}0=\text { painful } \\
1=\text { analgesia } \\
\text { to pinprick } \\
2=\text { anaesthesia } \\
\text { to pin- } \\
\text { prick (no per- } \\
\text { ception) } \\
\text { Global quality } \\
\text { scale = sum of } \\
\text { scores for all } 6 \\
\text { nerves }(0-12)\end{array}$ & $\begin{array}{l}\text { Musculocuta- } \\
\text { neous } \\
\text { Radial } \\
\text { Median } \\
\text { Ulnar } \\
\text { Medial } \\
\text { brachial cuta- } \\
\text { neous (arm?) } \\
\text { Medial an- } \\
\text { tebrachial cu- } \\
\text { taneous (fore- } \\
\text { arm?) }\end{array}$ & $\begin{array}{l}\text { Not } \\
\text { specifically } \\
\text { stated. Blocks } \\
\text { were supple- } \\
\text { mented pre- } \\
\text { operatively if } \\
\text { there was ab- } \\
\text { sence of com- } \\
\text { plete anaes- } \\
\text { thesia in surgi- } \\
\text { cal sites }\end{array}$ & $\begin{array}{l}\text { Elbow flexion } \\
\text { / extension } \\
\text { Wrist flexion / } \\
\text { extension } \\
\text { Fingers flexion } \\
\text { / extension } \\
\text { Thumb } \\
\text { adduction } \\
0 \text { = no paresis } \\
1=\text { paresis }\end{array}$ & Not reported \\
\hline
\end{tabular}




\begin{tabular}{|c|c|c|c|c|c|c|c|}
\hline & & & & & & $\begin{array}{l}2 \text { = complete } \\
\text { paralysis } \\
\text { Global quality } \\
\text { scale = sum of } \\
\text { scores for all } 7 \\
\text { areas ( } 0 \text { to } 14)\end{array}$ & \\
\hline $\begin{array}{l}\text { Rodriguez } \\
2008\end{array}$ & $\begin{array}{l}\text { Pinprick } \\
\text { with } 18 \mathrm{G} \text { long } \\
\text { bevel } \\
\text { needle }\end{array}$ & $\begin{array}{l}10,20, \text { and } \\
30 \text { minutes af- } \\
\text { ter injection of } \\
\text { the total dose } \\
\text { of LA (time } \\
\text { zero) }\end{array}$ & $\begin{array}{l}0 \text { points = pin- } \\
\text { prick } \\
\text { perceived as } \\
\text { painful } \\
1 \text { point = anal- } \\
\text { gesia to pin- } \\
\text { prick (tactile } \\
\text { sensation) } \\
2 \\
\text { points = anaes- } \\
\text { thesia to pin- } \\
\text { prick (no per- } \\
\text { ception) }\end{array}$ & $\begin{array}{l}\text { Musculocuta- } \\
\text { neous } \\
\text { Radial } \\
\text { Median } \\
\text { Ulnar } \\
\text { Medial cuta- } \\
\text { neous }\end{array}$ & $\begin{array}{l}\text { Global quality } \\
\text { scores for both } \\
\text { sensory block } \\
\text { (minimum, } \\
0 \text { point; maxi- } \\
\text { mum, } \\
12 \text { points) and } \\
\text { motor block } \\
\text { (mini- } \\
\text { mum, } 0 \text { point; } \\
\text { maximum, } 14 \\
\text { points) were } \\
\text { based on the } \\
\text { sum of the in- } \\
\text { dividual scores } \\
\text { obtained at } \\
10,20 \text {, and at } \\
30 \text { minutes in } \\
\text { each cu- } \\
\text { taneous nerve } \\
\text { distribution or } \\
\text { joint } \\
\text { movement. } \\
\text { "Blocks were } \\
\text { supplemented } \\
\text { preop- } \\
\text { eratively with } \\
\text { additional pe- } \\
\text { ripheral nerve } \\
\text { blocks when } \\
\text { the cutaneous } \\
\text { nerve dis- } \\
\text { tributions cor- } \\
\text { responding to } \\
\text { the oper- } \\
\text { ative area did } \\
\text { not have com- } \\
\text { plete anesthe- } \\
\text { sia (i.e., score } \\
<2 \text { ) before the } \\
\text { operation" }\end{array}$ & $\begin{array}{l}\text { Motor } \\
\text { block was as- } \\
\text { sessed for flex- } \\
\text { ion and exten- } \\
\text { sion of the el- } \\
\text { bow, } \\
\text { flexion and ex- } \\
\text { tension of the } \\
\text { wrist, flexion } \\
\text { and extension } \\
\text { of the fingers, } \\
\text { and adduction } \\
\text { of the thumb. } \\
0 \text { points = no } \\
\text { paresis } \\
1 \text { point = pare- } \\
\text { sis } \\
2 \\
\text { points = com- } \\
\text { plete paralysis }\end{array}$ & Not reported \\
\hline
\end{tabular}




\begin{tabular}{|c|c|c|c|c|c|c|c|}
\hline $\begin{array}{l}\text { Serradell } \\
\text { Catalan } 2001\end{array}$ & Pinprick & $\begin{array}{l}\text { Every } 10 \mathrm{~min} \text { - } \\
\text { utes up to } 40 \\
\text { minutes }\end{array}$ & $\begin{array}{l}\text { None: normal } \\
\text { sensation } \\
\text { Partial: anal- } \\
\text { gesia } \\
\text { Total: anaes- } \\
\text { thesia }\end{array}$ & $\begin{array}{l}\text { Medial cuta- } \\
\text { neous nerve of } \\
\text { forearm } \\
\text { Median } \\
\text { Musculocuta- } \\
\text { neous } \\
\text { Radial } \\
\text { Ulnar }\end{array}$ & $\begin{array}{l}\text { Success = sen- } \\
\text { sory blockade } \\
\text { for all } 5 \\
\text { nerves: } \\
\text { Medial cuta- } \\
\text { neous nerve of } \\
\text { forearm } \\
\text { Median } \\
\text { Musculocuta- } \\
\text { neous } \\
\text { Radial } \\
\text { Ulnar }\end{array}$ & $\begin{array}{l}\text { None: normal } \\
\text { movements } \\
\text { Partial: re- } \\
\text { duced move- } \\
\text { ments } \\
\text { Total: flaccid } \\
\text { hand and fore- } \\
\text { arm }\end{array}$ & $\begin{array}{l}\text { Median } \\
\text { Musculocuta- } \\
\text { neous } \\
\text { Radial } \\
\text { Ulnar }\end{array}$ \\
\hline Sia 2001 & $\begin{array}{l}\text { Used } 22 \text { gauge } \\
\text { needle }\end{array}$ & $\begin{array}{l}\text { Every } 10 \mathrm{~min} \text { - } \\
\text { utes up to } 30 \\
\text { minutes }\end{array}$ & $\begin{array}{l}\text { Analgesia: loss } \\
\text { of pinprick } \\
\text { Anaesthesia: } \\
\text { loss of touch }\end{array}$ & $\begin{array}{l}\text { Medial cuta- } \\
\text { neous nerve of } \\
\text { arm } \\
\text { Medial cuta- } \\
\text { neous nerve of } \\
\text { forearm } \\
\text { Median } \\
\text { Musculocuta- } \\
\text { neous } \\
\text { Radial } \\
\text { Ulnar }\end{array}$ & $\begin{array}{l}\text { Suc- } \\
\text { cess = com- } \\
\text { plete block of } \\
\text { all } 6 \text { nerves: } \\
\text { Medial cuta- } \\
\text { neous nerve of } \\
\text { arm } \\
\text { Medial cuta- } \\
\text { neous nerve of } \\
\text { forearm } \\
\text { Median } \\
\text { Musculocuta- } \\
\text { neous } \\
\text { Radial } \\
\text { Ulnar }\end{array}$ & $\begin{array}{l}\text { Absent: no } \\
\text { block } \\
\text { Satis- } \\
\text { factory: minor } \\
\text { movements of } \\
\text { digits possible } \\
\text { Complete: no } \\
\text { movements } \\
\text { against gravity }\end{array}$ & Not reported \\
\hline Sia $2010 \mathrm{a}$ & Cold test & $\begin{array}{l}5, \quad 10, \\
15,20,25 \text { and } \\
30 \text { minutes af- } \\
\text { ter end of pro- } \\
\text { cedure }\end{array}$ & $\begin{array}{l}\text { Yes = "I feel } \\
\text { cold" } \\
\text { No = "I do not } \\
\text { feel cold" }\end{array}$ & $\begin{array}{l}\text { Musculocuta- } \\
\text { neous } \\
\text { Median } \\
\text { Radial } \\
\text { Ulnar } \\
\text { Medial cuta- } \\
\text { neous }\end{array}$ & $\begin{array}{l}\text { Loss of cold } \\
\text { sensation at } 30 \\
\text { minutes suffi- } \\
\text { cient for } \\
\text { surgery. } \\
\text { Unblocked } \\
\text { nerves impli- } \\
\text { cated in the } \\
\text { surgical site } \\
\text { were blocked } \\
\text { by the anaes- } \\
\text { thesiologist. } \\
\text { Intraop- } \\
\text { eratively, if the } \\
\text { patient com- } \\
\text { plained } \\
\text { of pain at the } \\
\text { surgical field, } \\
\text { supplemen- }\end{array}$ & $\begin{array}{l}\text { Motor } \\
\text { block was as- } \\
\text { sessed for wrist } \\
\text { exten- } \\
\text { sion, forearm } \\
\text { flexion, index } \\
\text { flexion, little } \\
\text { finger flexion. } \\
\text { Grade } 1=\text { no } \\
\text { loss of force } \\
\text { Grade } 2=\text { re- } \\
\text { duced force } \\
\text { compared } \\
\text { with con- } \\
\text { tralateral arm } \\
\text { Grade } 3= \\
\text { complete mo- } \\
\text { tor block }\end{array}$ & Not reported \\
\hline
\end{tabular}




\begin{tabular}{|c|c|c|c|c|c|c|c|}
\hline & & & & & $\begin{array}{l}\text { tation with LA } \\
\text { was done by } \\
\text { the surgeon. }\end{array}$ & & \\
\hline Sia $2010 \mathrm{~b}$ & Cold test & $\begin{array}{l}5, \quad 10, \\
15,20,25 \text { and } \\
30 \text { minutes af- } \\
\text { ter end of pro- } \\
\text { cedure }\end{array}$ & $\begin{array}{l}\text { Yes = "I feel } \\
\text { cold" } \\
\text { No = "I do not } \\
\text { feel cold" }\end{array}$ & $\begin{array}{l}\text { Musculocuta- } \\
\text { neous } \\
\text { Median } \\
\text { Radial } \\
\text { Ulnar } \\
\text { Medial cuta- } \\
\text { neous }\end{array}$ & $\begin{array}{l}\text { Loss of cold } \\
\text { sensation at } 30 \\
\text { minutes suffi- } \\
\text { cient for } \\
\text { surgery. } \\
\text { Unblocked } \\
\text { nerves impli- } \\
\text { cated in the } \\
\text { surgical site } \\
\text { were blocked } \\
\text { by the anaes- } \\
\text { thesiologist. } \\
\text { Intraop- } \\
\text { eratively, if the } \\
\text { patient com- } \\
\text { plained } \\
\text { of pain at the } \\
\text { surgical field, } \\
\text { supplemen- } \\
\text { tation with LA } \\
\text { was done by } \\
\text { the surgeon. }\end{array}$ & $\begin{array}{l}\text { Motor } \\
\text { block was as- } \\
\text { sessed for wrist } \\
\text { exten- } \\
\text { sion, forearm } \\
\text { flexion, index } \\
\text { flexion, little } \\
\text { finger flexion. } \\
\text { Grade } 1 \text { = no } \\
\text { loss of force } \\
\text { Grade } 2=\text { re- } \\
\text { duced force } \\
\text { compared } \\
\text { with con- } \\
\text { tralateral arm } \\
\text { Grade } 3= \\
\text { complete mo- } \\
\text { tor block }\end{array}$ & Not reported \\
\hline Sia 2010c & Cold test & $\begin{array}{l}5, \quad 10, \\
15,20,25 \text { and } \\
30 \text { minutes af- } \\
\text { ter end of pro- } \\
\text { cedure }\end{array}$ & $\begin{array}{l}\text { Yes = "I feel } \\
\text { cold" } \\
\text { No = "I do not } \\
\text { feel cold" }\end{array}$ & $\begin{array}{l}\text { Musculocuta- } \\
\text { neous } \\
\text { Median } \\
\text { Radial } \\
\text { Ulnar } \\
\text { Medial cuta- } \\
\text { neous }\end{array}$ & $\begin{array}{l}\text { Loss of cold } \\
\text { sensation at } 30 \\
\text { minutes suffi- } \\
\text { cient for } \\
\text { surgery. } \\
\text { Unblocked } \\
\text { nerves impli- } \\
\text { cated in the } \\
\text { surgical site } \\
\text { were blocked } \\
\text { by the anaes- } \\
\text { thesiologist. } \\
\text { Intraop- } \\
\text { eratively, if the } \\
\text { patient com- } \\
\text { plained } \\
\text { of pain at the } \\
\text { surgical field, } \\
\text { supplemen- } \\
\text { tation with LA } \\
\text { was done by } \\
\text { the surgeon. }\end{array}$ & $\begin{array}{l}\text { Motor } \\
\text { block was as- } \\
\text { sessed for wrist } \\
\text { exten- } \\
\text { sion, forearm } \\
\text { flexion, index } \\
\text { flexion, little } \\
\text { finger flexion. } \\
\text { Grade } 1 \text { = no } \\
\text { loss of force } \\
\text { Grade } 2=\text { re- } \\
\text { duced force } \\
\text { compared } \\
\text { with con- } \\
\text { tralateral arm } \\
\text { Grade } 3= \\
\text { complete mo- } \\
\text { tor block }\end{array}$ & Not reported \\
\hline
\end{tabular}




\begin{tabular}{|c|c|c|c|c|c|c|c|}
\hline Turkan 2002 & $\begin{array}{l}\text { Pinprick } \\
\text { Testing } \\
\text { with an Allis } \\
\text { clamp by sur- } \\
\text { geon also } \\
\text { mentioned }\end{array}$ & $\begin{array}{l}\text { Sensory test- } \\
\text { ing } \\
\text { every } 3 \text { min- } \\
\text { utes following } \\
\text { injection. No } \\
\text { other details. }\end{array}$ & $\begin{array}{l}\text { Quality of } \\
\text { analgesia } \\
1=\text { no pain } \\
2=\text { discom- } \\
\text { fort } \\
3=\text { pain }\end{array}$ & $\begin{array}{l}\text { Musculocuta- } \\
\text { neous } \\
\text { Median } \\
\text { Radial } \\
\text { Ulnar }\end{array}$ & $\begin{array}{l}\text { Over- } \\
\text { all block suc- } \\
\text { cess was when } \\
\text { the patient felt } \\
\text { no pain in all } \\
\text { four nerve dis- } \\
\text { tri- } \\
\text { butions when } \\
\text { tested by a sur- } \\
\text { geon (with an } \\
\text { Allis clamp). }\end{array}$ & Not reported & Not reported \\
\hline
\end{tabular}

\section{WHAT'S NEW}

Last assessed as up-to-date: 13 March 2011.

\begin{tabular}{|c|c|c|}
\hline Date & Event & Description \\
\hline 14 March 2011 & Amended & The review was amended to the format of RevMan 5.1. \\
\hline 14 March 2011 & New search has been performed & $\begin{array}{l}\text { We updated the review as follows. } \\
\text { 1. The title was changed to make it explicit that the scope } \\
\text { is restricted to adults. } \\
\text { 2. The inclusion criteria were revised to exclude children } \\
\text { and trials using ultrasound-guided techniques of nerve } \\
\text { location. } \\
\text { 3. We now assess risk of bias; this replaced the previous } \\
\text { methodological quality assessment. } \\
\text { 4. We updated our literature search from March } 2005 \\
\text { (date of last search in the previous review) to March } \\
\text { 2011. } \\
\text { 5. We included eight new trials (Hickey } 1993 \text {; Imbelloni } \\
\text { 2005; Rodriguez 2005; Rodriguez 2008; Sia 2010a; Sia } \\
\text { 2010b; Sia 2010c; Turkan 2002). We excluded a further } \\
\text { seven newly identified studies (Carre 2000; Liu 2005; } \\
\text { Sites 2006; Tuominen } 1987 \text {; Youssef 1988; Yu 2007). } \\
\text { One trial (Ramirez-Gomez 2010) is currently awaiting } \\
\text { translation and classification. } \\
\text { 6. We added summary of findings tables for the three } \\
\text { comparisons. }\end{array}$ \\
\hline
\end{tabular}

14 March 2011 New citation required but conclusions have not changed

This review is an update of the previous Cochrane systematic review (Handoll 2006). There is a change in authorship, including the lead author and the contact author: Zbigniew J Koscielniak-Nielsen has been replaced 


\section{H I S T O R Y}

Protocol first published: Issue 4, 2002

Review first published: Issue 1, 2006

\begin{tabular}{lll}
\hline Date & Event & Description \\
\hline 31 July 2008 & Amended & Converted to new review format. \\
\hline
\end{tabular}

\section{CONTRIBUTIONS OFAUTHORS}

\section{Updated review}

Conceiving the review: Dr KJ Chin, Dr H Handoll

Co-ordinating the review: Dr KJ Chin, Dr H Handoll

Undertaking manual searches: Dr KJ Chin

Screening search results: Dr KJ Chin, Dr H Handoll

Organizing retrieval of papers: Dr KJ Chin, Dr H Handoll

Screening retrieved papers against inclusion criteria: Dr KJ Chin, Dr H Handoll

Appraising quality of papers: Dr KJ Chin, Dr H Handoll

Abstracting data from papers: Dr KJ Chin, Dr H Handoll

Writing to authors of papers for additional information: Dr KJ Chin

Providing additional data about papers: not applicable

Obtaining and screening data on unpublished studies: not applicable

Data management for the review: Dr KJ Chin, Dr H Handoll

Entering data into Review Manager (RevMan 5.1): Dr KJ Chin, Dr H Handoll

RevMan statistical data: Dr KJ Chin, Dr H Handoll

Other statistical analysis not using RevMan: Dr H Handoll

Interpretation of data: Dr KJ Chin

Statistical inferences: Dr H Handoll

Writing the review: Dr KJ Chin, Dr H Handoll

Securing funding for the review: not applicable

Performing previous work that was the foundation of the present study: Dr H Handoll (lead author of previous version)

Guarantor for the review (one author): Dr KJ Chin

Person responsible for reading and checking review before submission: Dr KJ Chin

\section{Original review}

See Handoll 2006

Dr ZJ Koscielnak-Nielsen conceived the idea for the review and wrote the protocol.

Dr H Handoll and Dr ZJ Koscielnak-Nielsen wrote the review. 


\section{DECLARATIONS OF INTEREST}

None known

\section{SOURCES OF SUPPORT}

\section{Internal sources}

- University of Teesside, Middlesbrough, UK.

- Department of Anaesthesia and Operative Services, HOC, Rigshospital, Copenhagen, Denmark.

- University of Toronto, Toronto, Canada.

\section{External sources}

- No sources of support supplied

\section{DIFFERENCES BETWEEN PROTOCOLANDREVIEW}

\section{Changes made for the first update of the review}

Changes made to the inclusion criteria and methods before processing the included trials were as follows.

1. We clarified that we would exclude trials focusing on children only (Types of participants). The restriction to adults was made explicit in the title of the review.

2. We excluded trials that used ultrasound-guided techniques of nerve location.

Risk of bias assessment replaced the eight-item methodological quality assessment scoring scheme.

\section{Changes made for the first version of the review}

Important changes made to the protocol before processing the included trials were as follows.

1. The midhumeral approach was no longer specified as included (Types of studies).

2. The exclusion of trials involving supplementary anaesthesia was moderated to allow for trials using systemic opioids as a component of sedation (Types of interventions).

3. The addition of a third primary outcome, failed anaesthesia (Types of outcome measures).

4. Adjustments to the methods to accommodate the change in review authorship (Methods).

5. The expansion of the quality assessment of the included trials to include all eight items suggested in the generic scoring scheme of CARG (Methods).

6. The prior specification of sensitivity and subgroup analyses.

Before publication of the review (Handoll 2006), the name was changed from that in the protocol: Single, double or multiple injection techniques for axillary brachial plexus block for surgery of the distal upper extremity. 


\section{N D EX TERMS}

\section{Medical Subject Headings (MeSH)}

*Brachial Plexus; Anesthetics, Local [*administration \& dosage]; Axilla [innervation]; Forearm [*surgery]; Hand [*surgery]; Nerve Block [ ${ }^{*}$ methods]; Randomized Controlled Trials as Topic; Wrist [surgery]

\section{MeSH check words}

Humans 